\title{
منهج ابن خلدون في التعاطي مع النصوص الشرعية في موضوع السلطة والعصبية: فهماً وتحليلاً
}

\section{عبداللة إبر اهيم زيد الكيلاني*}

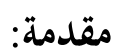

تحاول هذه الدراسة أن تكشف عن مكانة الدولة وأهميتها للعمران الاجتماعي في

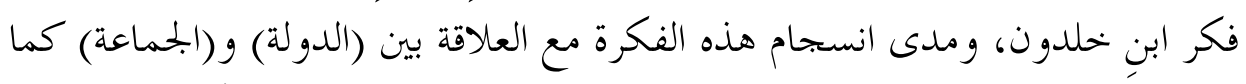

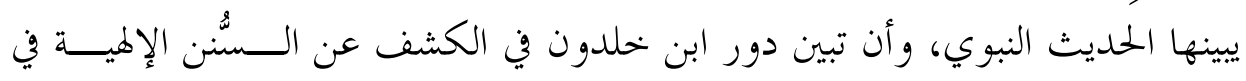

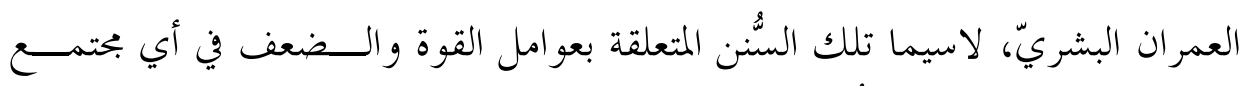

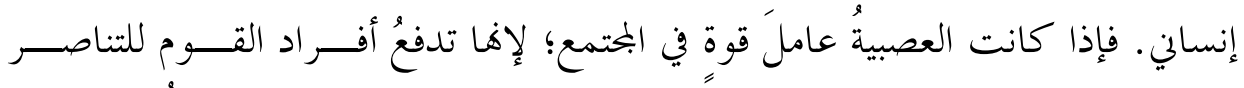

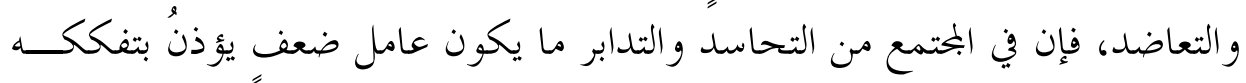

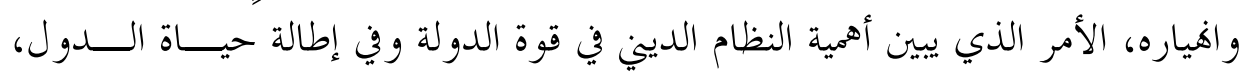

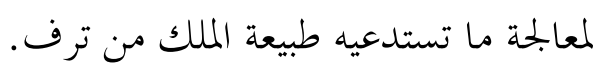

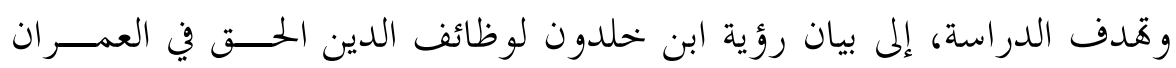

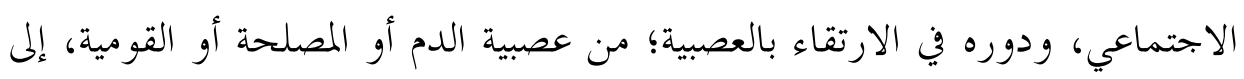

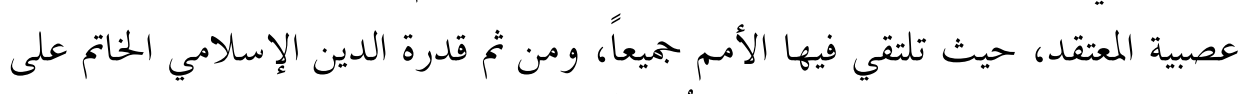

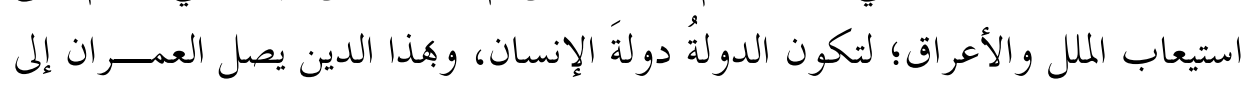

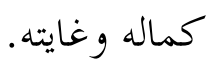

لقد أدرك ابن خلدون أثر الدين في هُذيب النفوس، فضلاً عن وظيفة النظام الديني

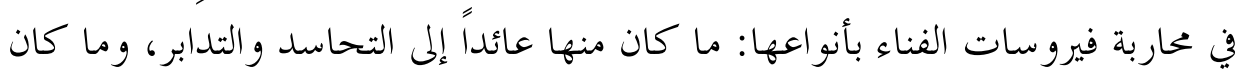


عائداً إلى قسوة الحاكم وتنقيبه عن العورات، فيؤول الأمر إلى أن تلوذ الرعية بــالمكر والخداع لحماية نفسها، فتفسد الدولةُ بفساد النيات.

وتحاول هذه الدارسة، الكشف عن المنهج العلمي الذي سار عليه ابن خلدون في

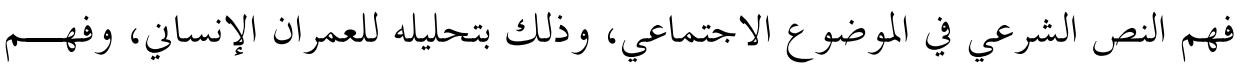

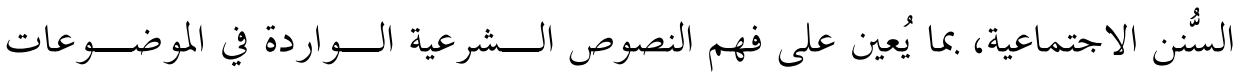

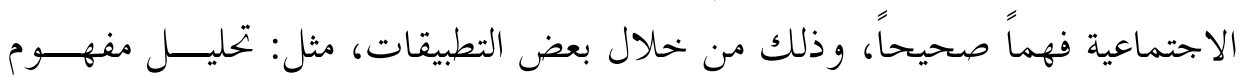

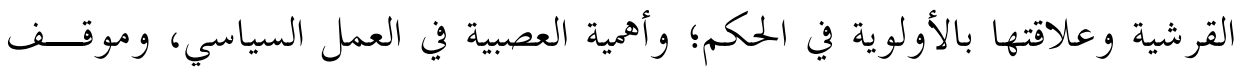

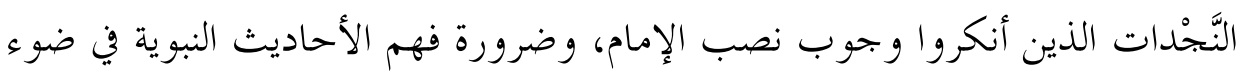

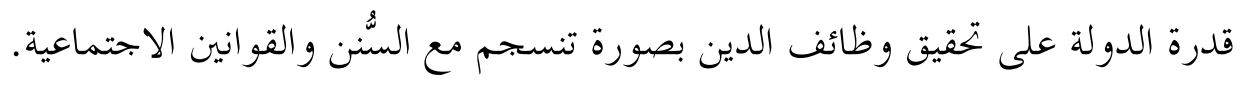
ويكشف البحث عن ارتباط النتائج التي قرّرها ابنُ خلدوون، بما يرشد إليه المنهج

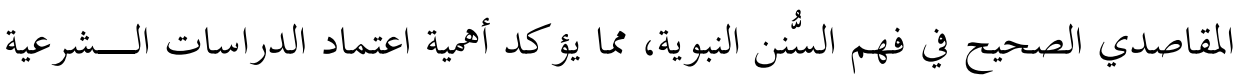

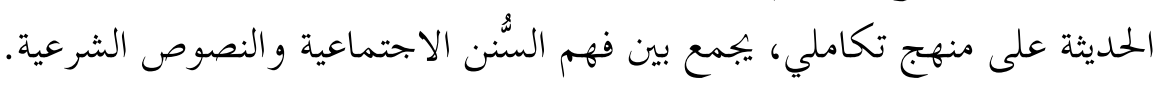

أولاً: العمران البشريّ عند ابن خلدون بين الرؤية القر آنية والفلسفة اليونانية:

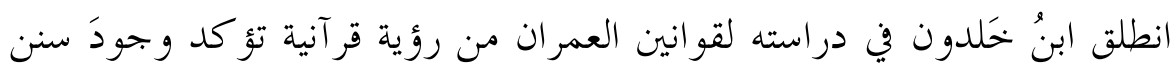

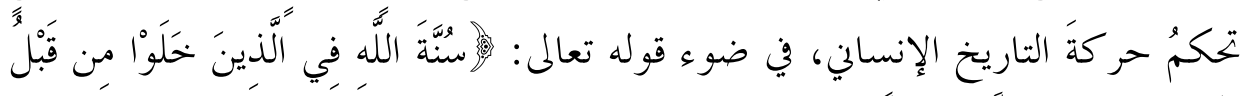

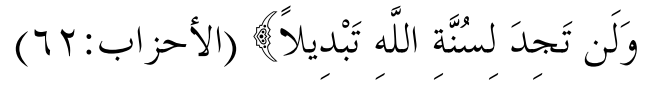

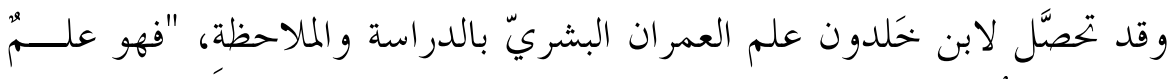

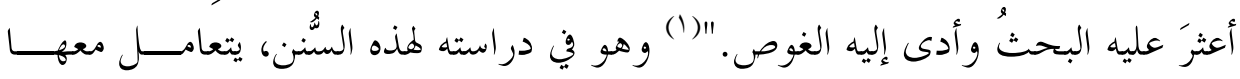

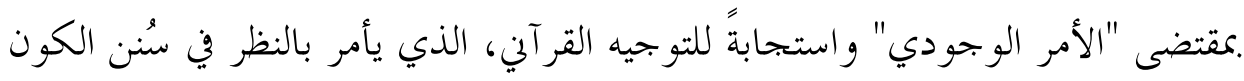

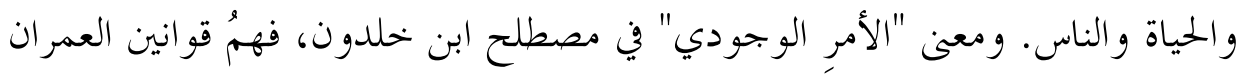

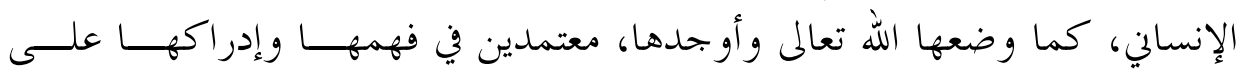

ابن خلدون، عبدالرمن. المقدمة، بيروت: مكتبة المدرسة ودار الكتاب اللبناني للطباعة والنسشر، 9V9 1)، 


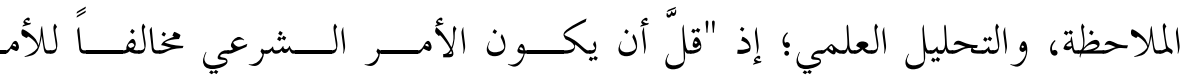

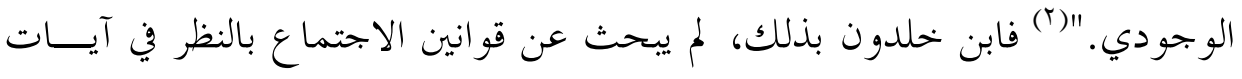

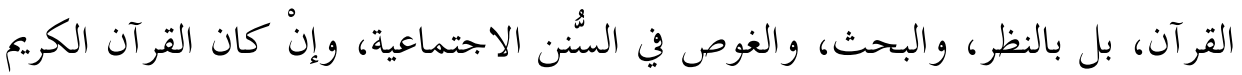

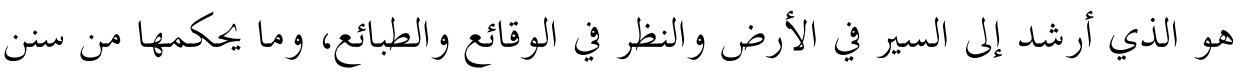

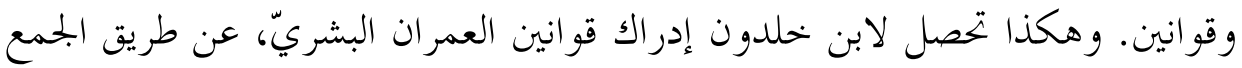

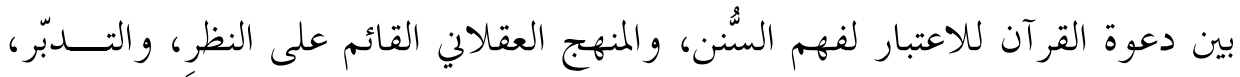

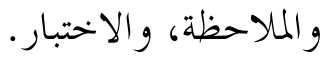

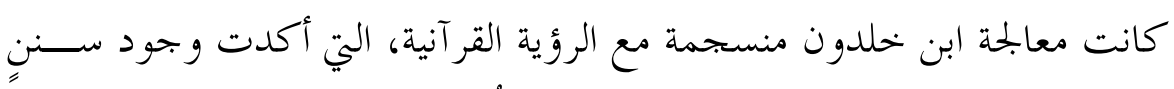

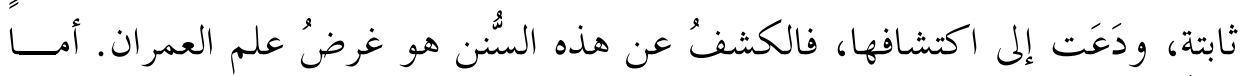

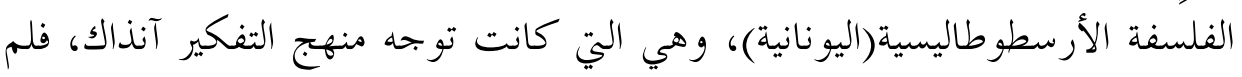

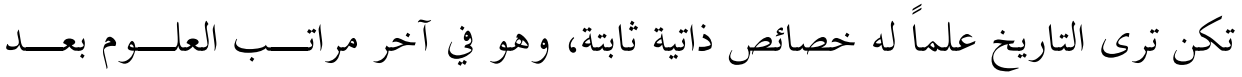

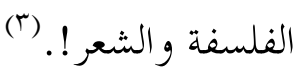

وقد استخدم ابنُ خلدون مصطلحات الفلسفة: "كالذاتي" و "العرَضي"، ولكنـــه

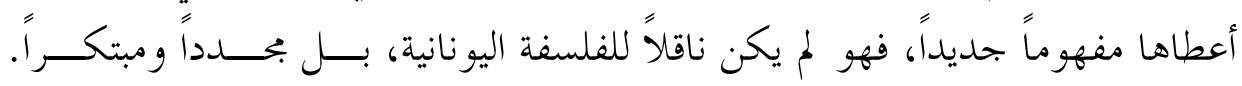

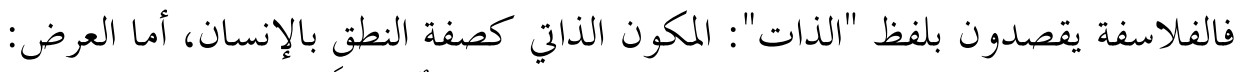

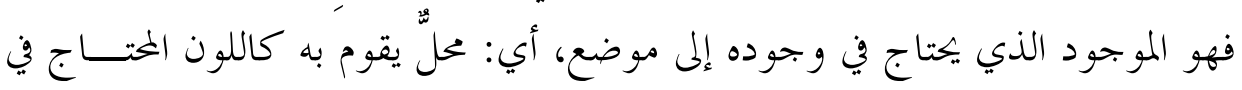

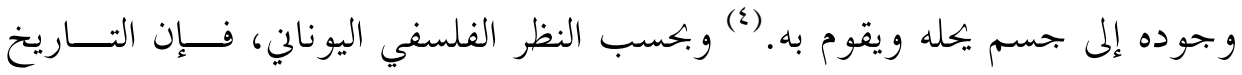

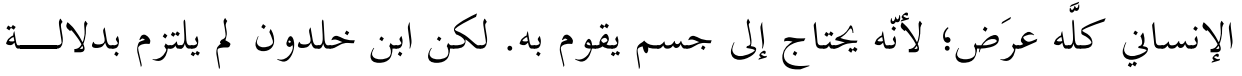

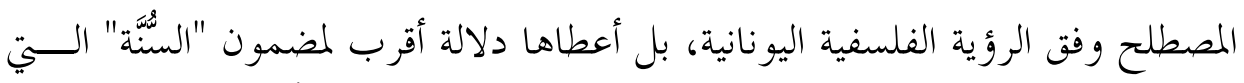

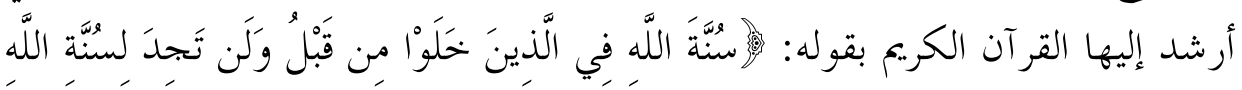

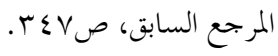

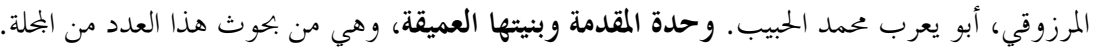

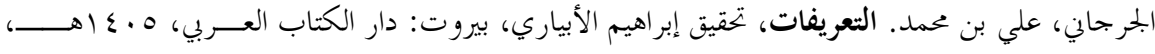

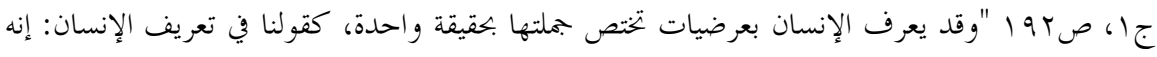

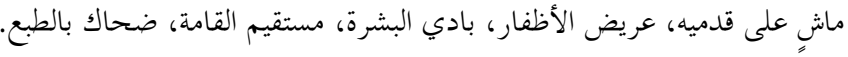




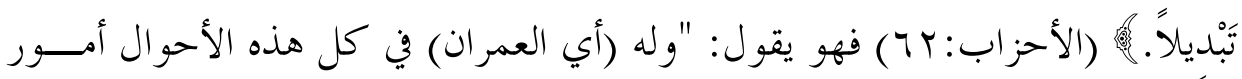

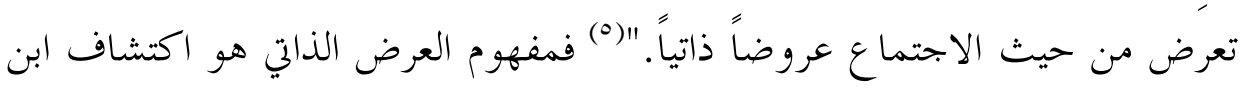

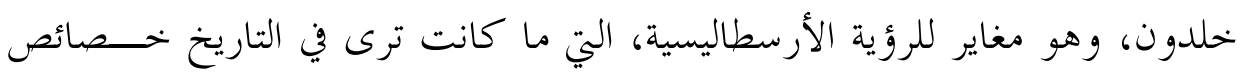

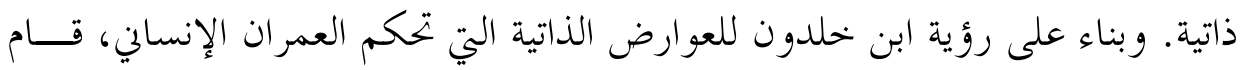

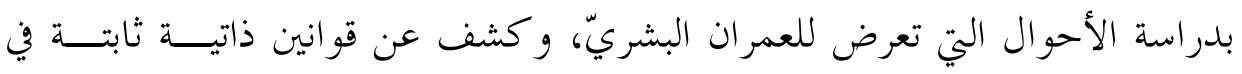

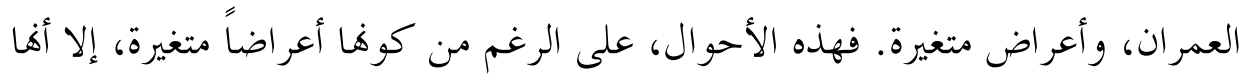

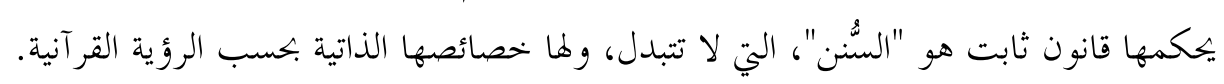
ومن هنا يتضح أن ابن خلدون كان ابن الحضارة الإسلامية، ومن رحم الرؤيسـة

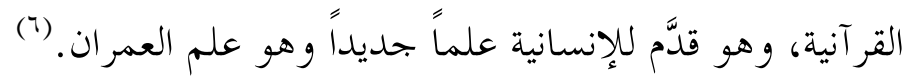

\section{ثانياً: موقع الدولة من العمران: - مان}

انطلق ابنُ خلدون في دراسته للعمر ان البشريّ وتطوره، من مرحلة البداوة وصولاً

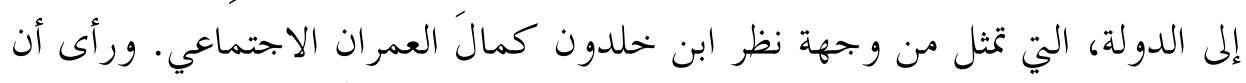

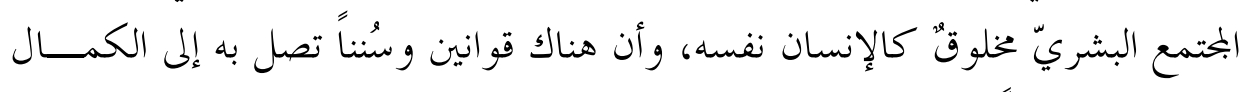

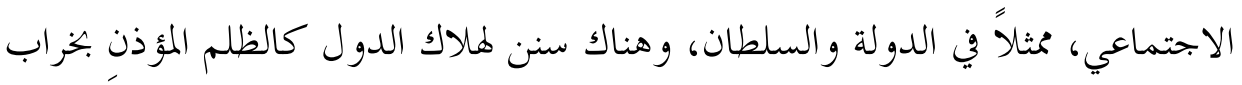

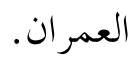

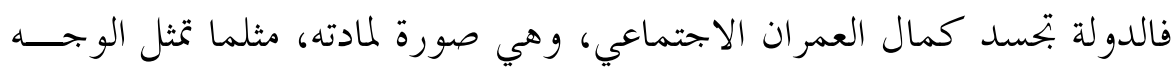

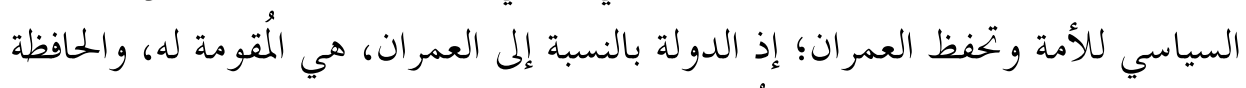

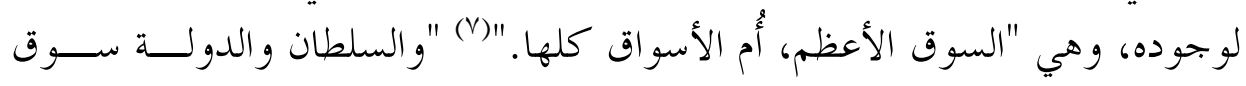

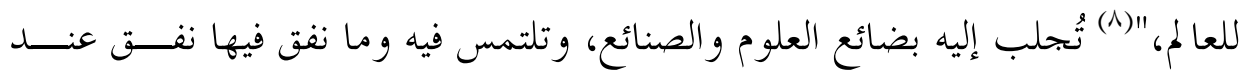

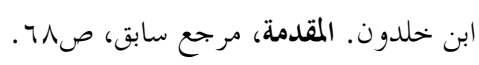

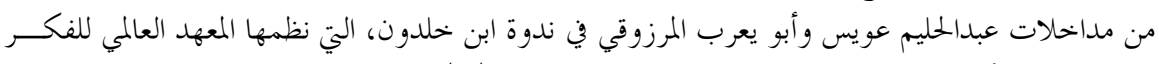

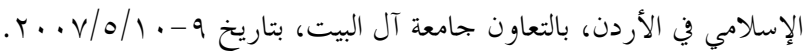

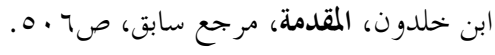

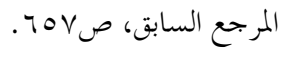


الكافة. "وإن الحضارة في الأمصار، تستمد من قبل الدولة، وإنما ترسخ باتصال الدولة

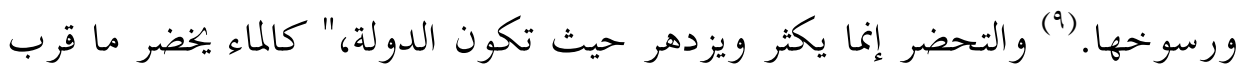

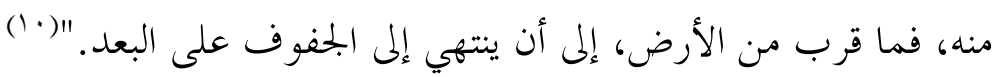

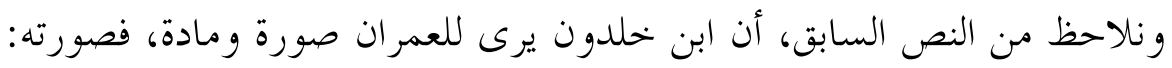

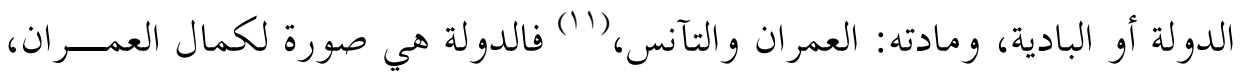

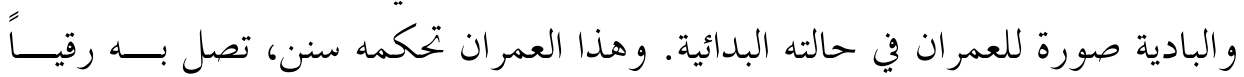
للكمال، أو هبوطاً إلى الفساد.

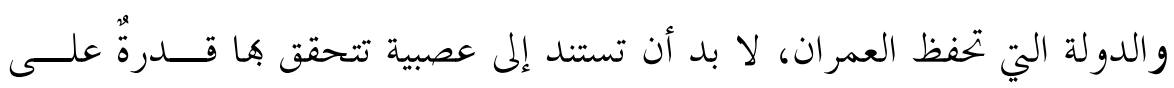

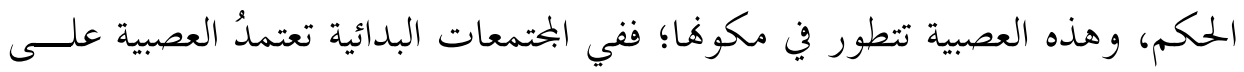

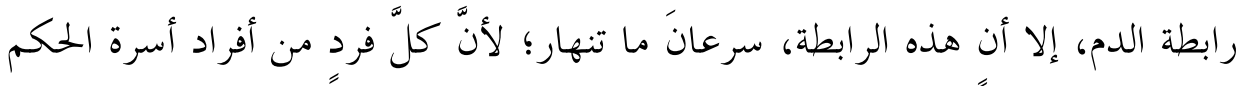

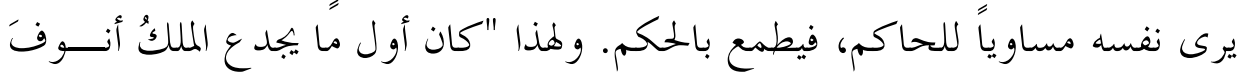

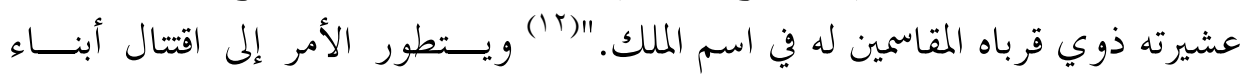

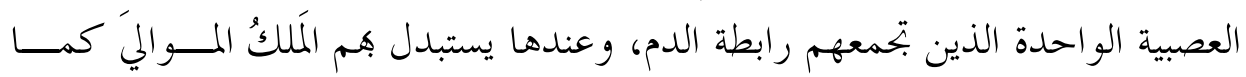

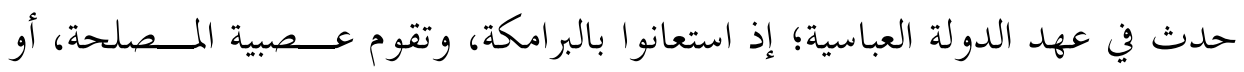

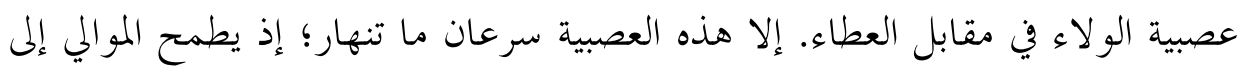

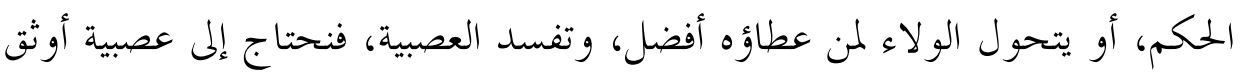

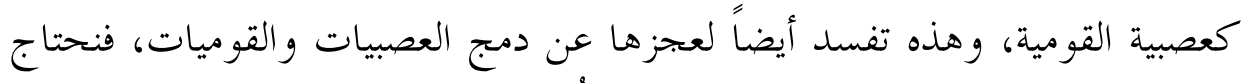

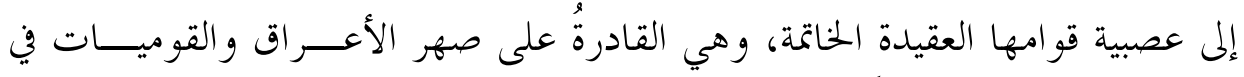

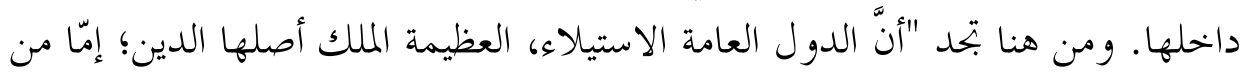

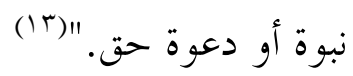

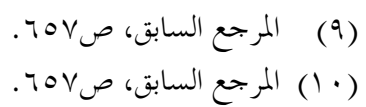

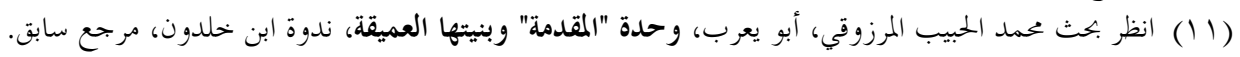

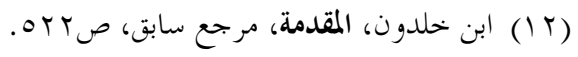

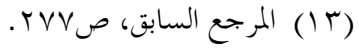




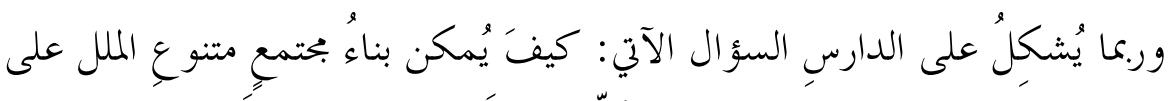

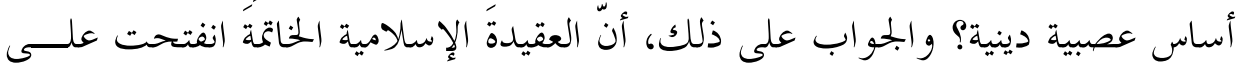

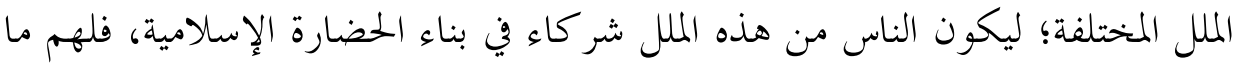

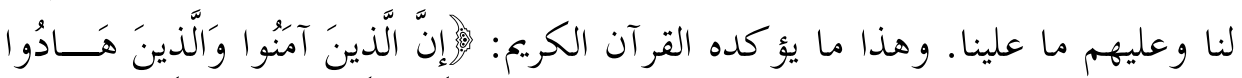

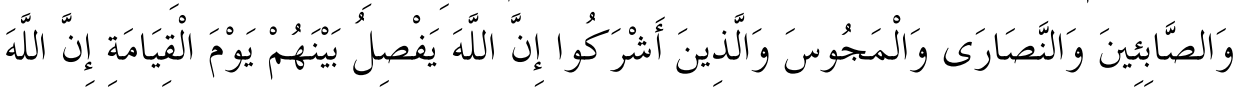

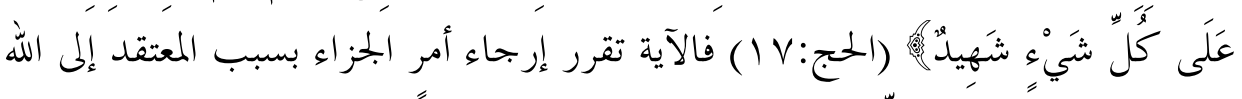

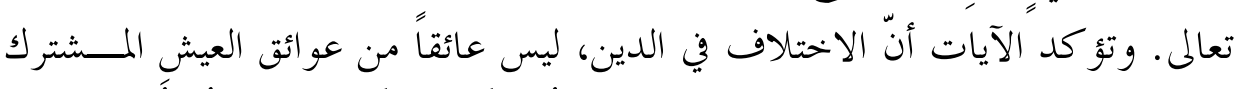

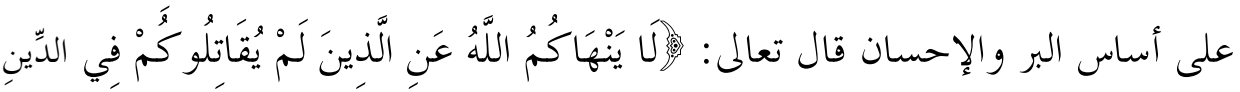

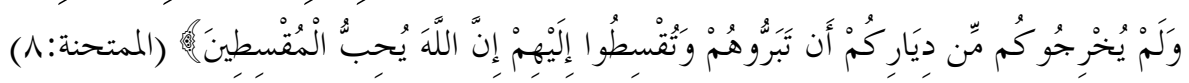

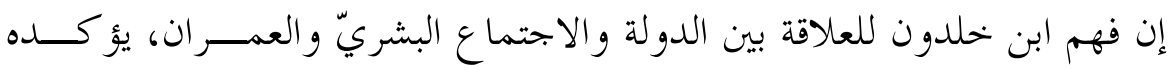

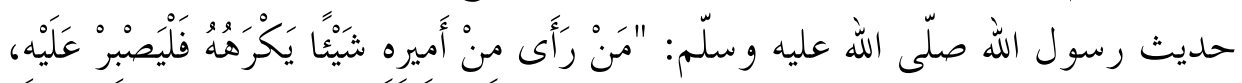

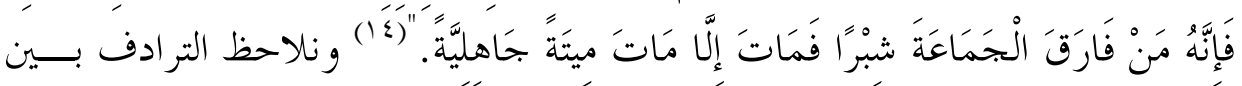

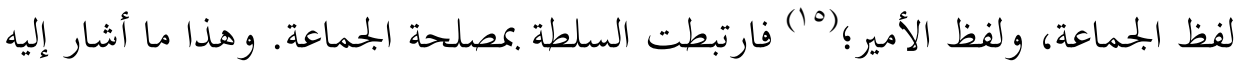

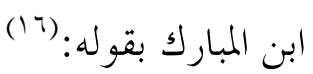

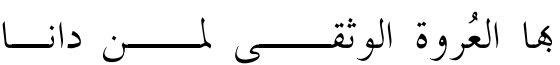

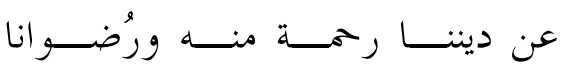

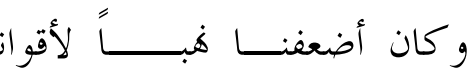

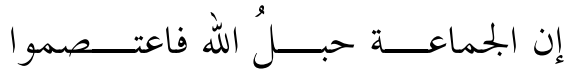

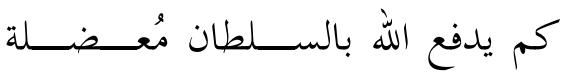

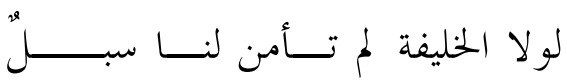

ونلاحظ من كلام ابن المبارك السابق، أنه يستخدم لفظ "الجماعة" بمعنى مرادف

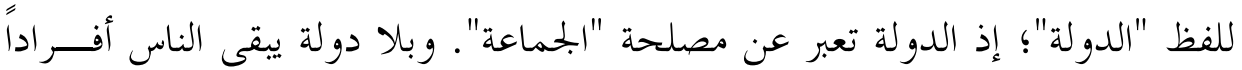

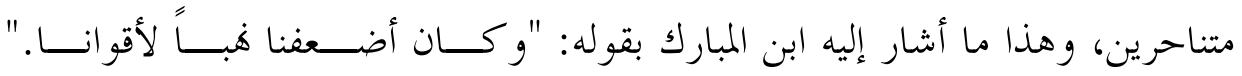
(\{ () البخاري، كمد بن إسماعيل. صحيح البخاري متن فتح الباري، ترقيم كمد فــؤاد عبــالباقي، التـاهرة:

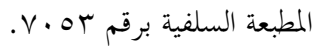

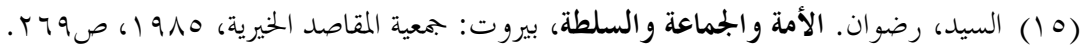

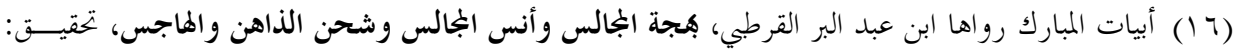

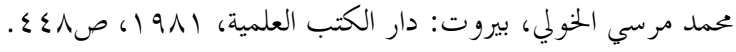


فالشخصية الاعتبارية للجماعة تتحقق اكتمالاً في ظل الدولة. تم إنّ الــسلطة العليــا

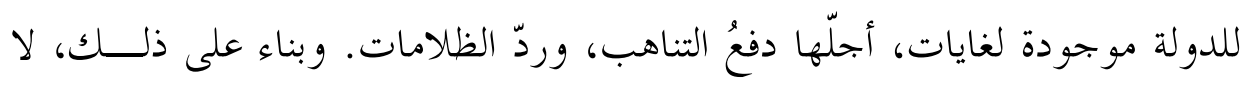

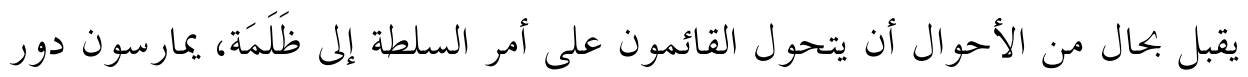

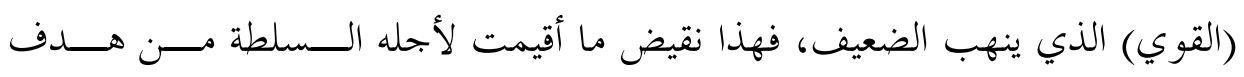
جليل. (القوي (ال)

و الترادف بين مصطلح "الجماعة"، ومصطلح "الأمير" في الحديث النبوي، يـــل

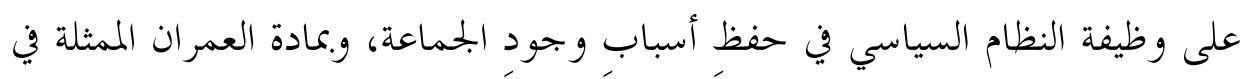
التنمية الاقتصادية، وفي حفظ أخلاق المجتمع؛ دعامة للتآنس. وللترادف في مصطلحي الجماعة والأمير في الحديث النبوي، دلالة عميقةٌ في بيان

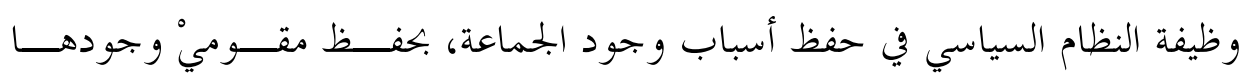

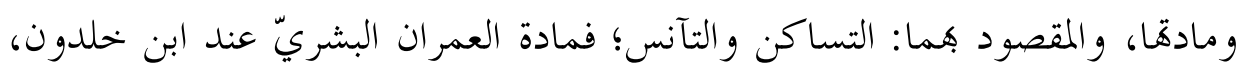

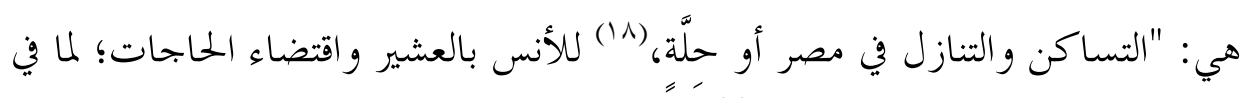

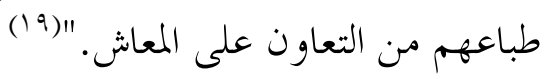

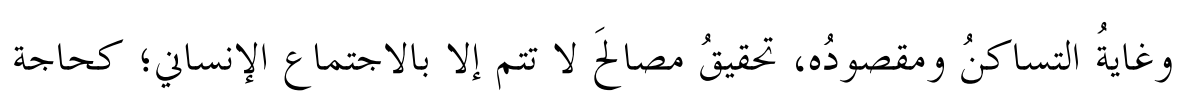

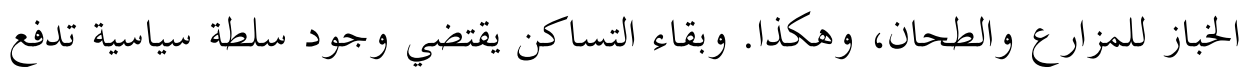

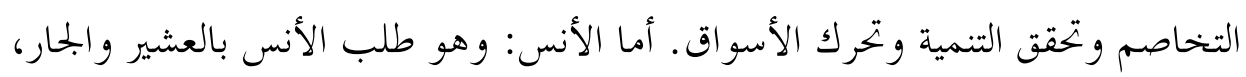

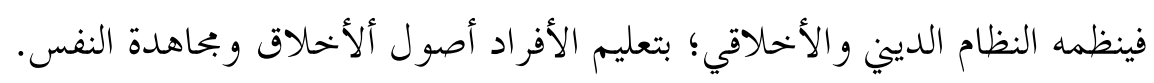

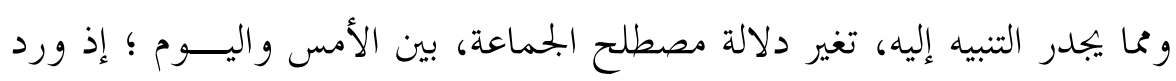

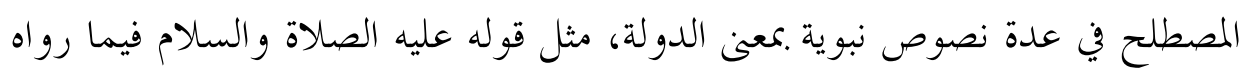

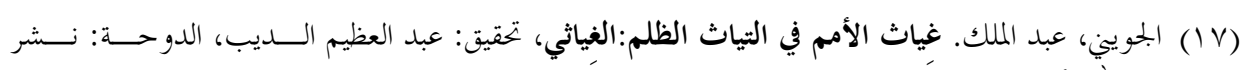

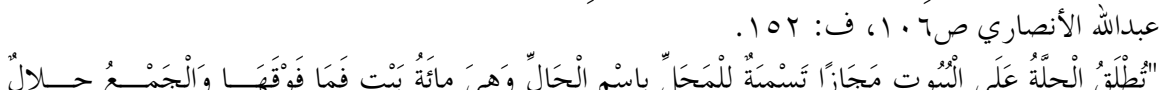

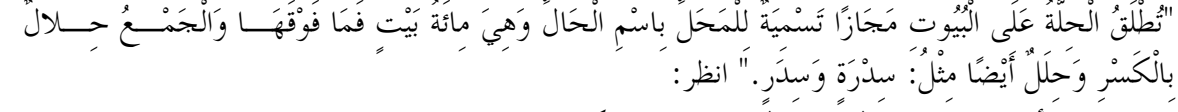

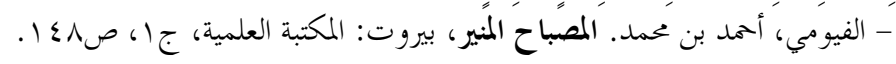

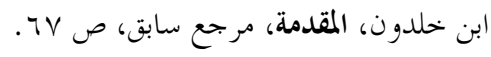




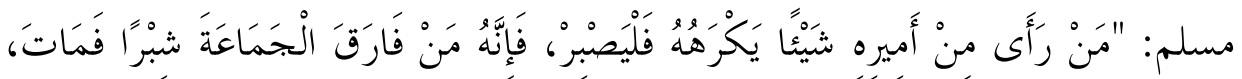

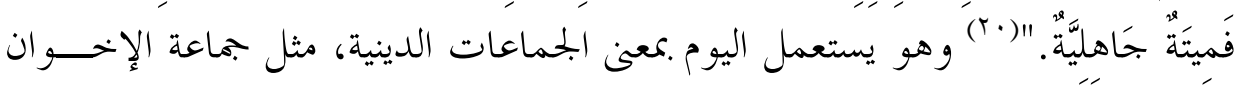

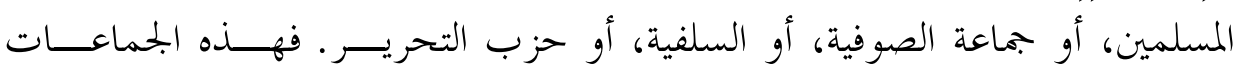

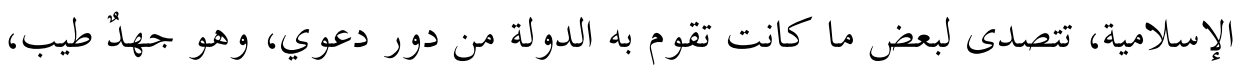

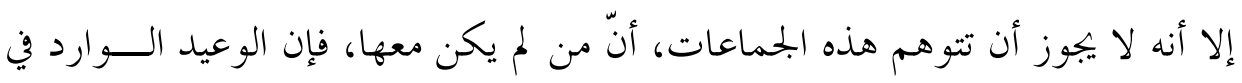

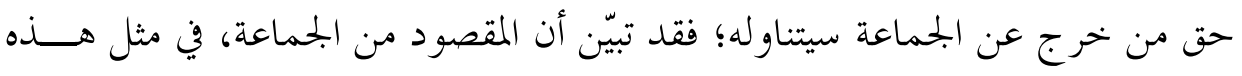

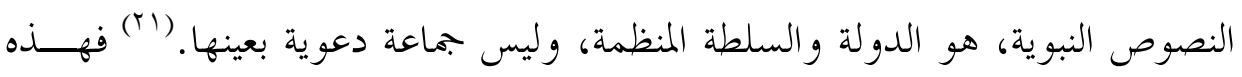

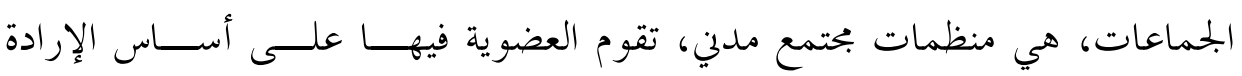

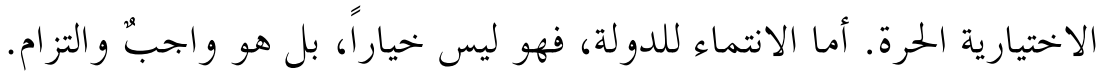

وإذا تحولت السلطة السياسة عن وظيفتها، فبدأت بإعاقة أسباب التنمية من خحلال

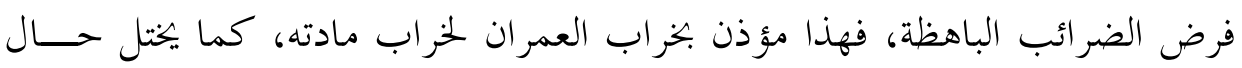

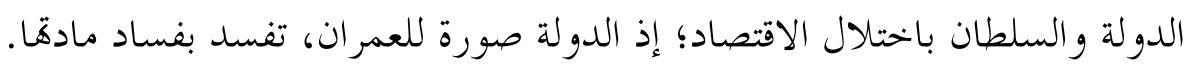
وقد ضرب ابن خلدون لذالك حكاية أخذها من المسعودي؛ إذ روى الموبــــان، إنهان.

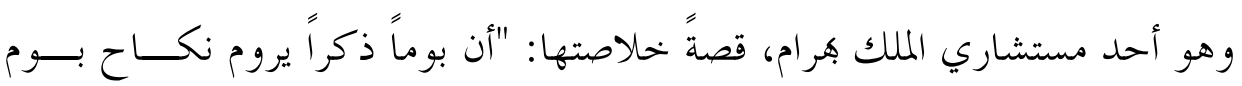

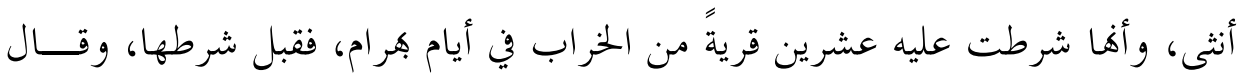

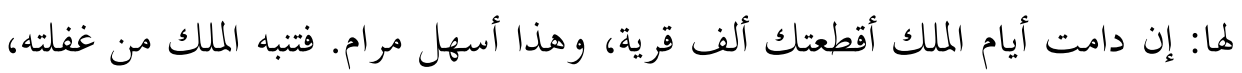

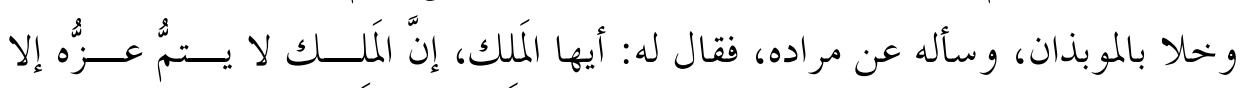

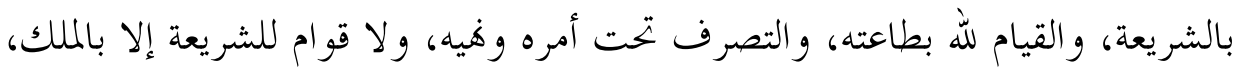

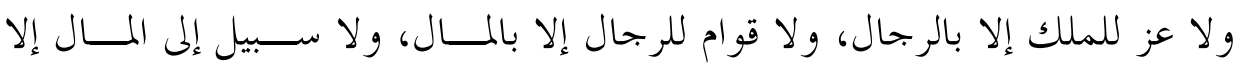

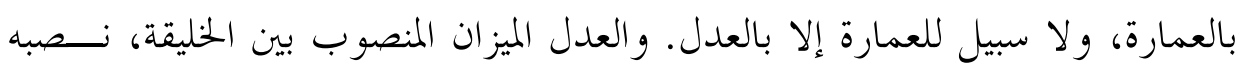

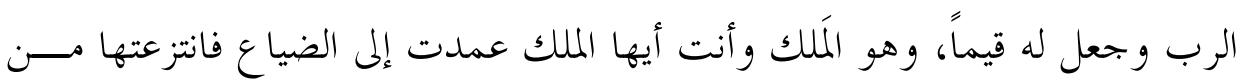

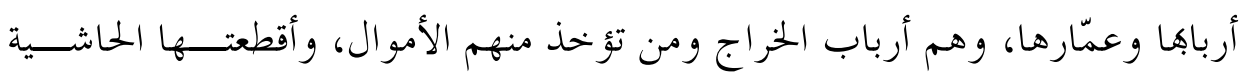

(Y. (Y. مسلم، الإمام مسلم بن الحجاج. الجامع الصحيح، تحتيق: عمد فؤاد عبدالباقي، بيروت: دار إحياء التراث

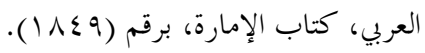

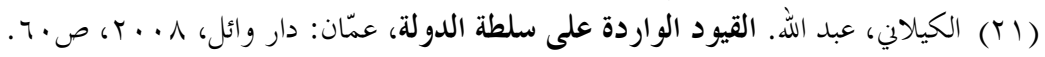


والخدم وأهل البطالة، فتركوا العمارة، والنظر في العواقب وما يصلح الضياع، فقلّت

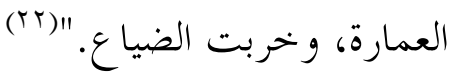

ويقول ابن خلدون: "و اعلم أن هذه هي الحكمة المقصودة للـششارع في تحـــيم

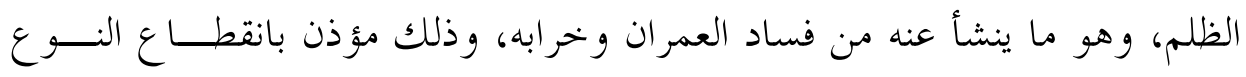

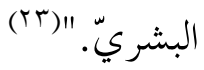

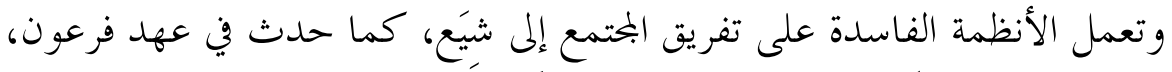

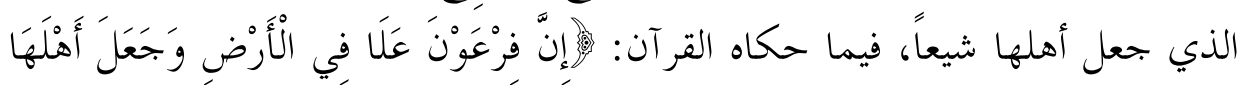

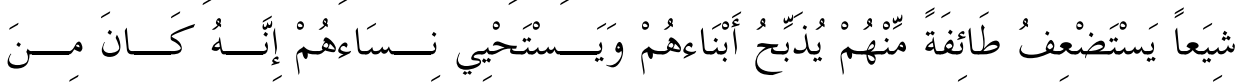

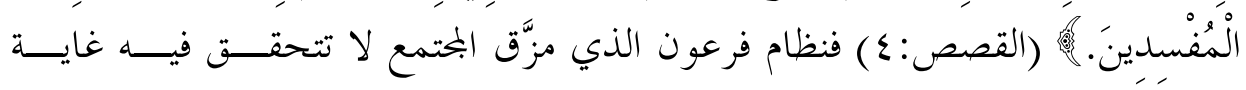

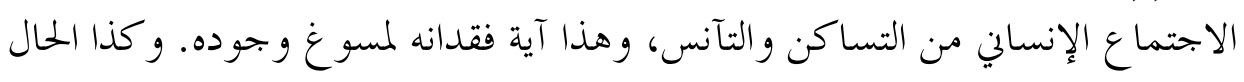

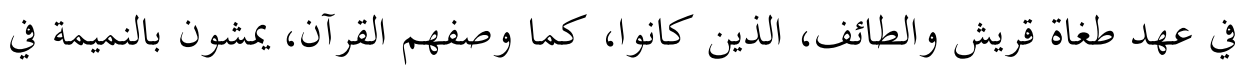

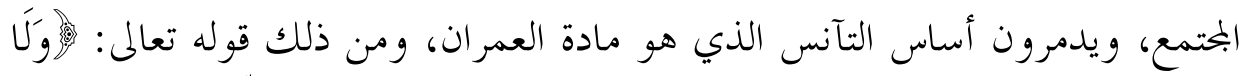

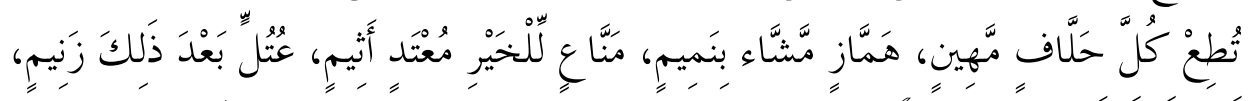

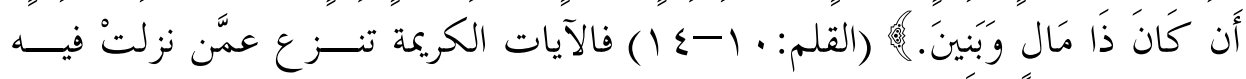

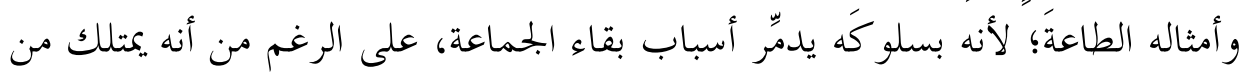

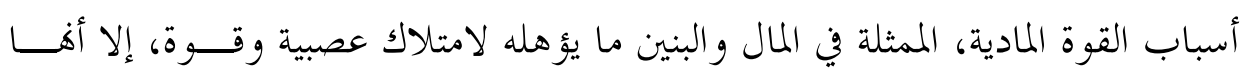
عصبية فاسدة؛ لأها لا تؤدي غايتها من التساكن، و التآنس.

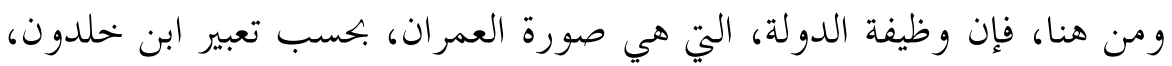

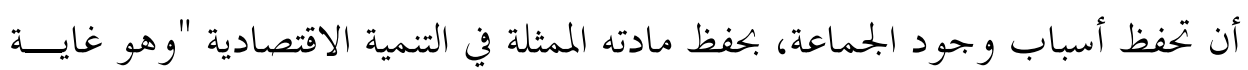

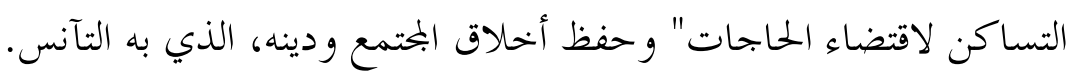

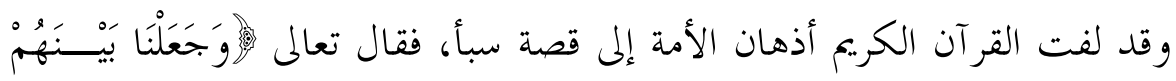

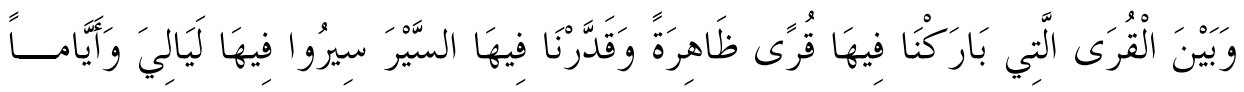

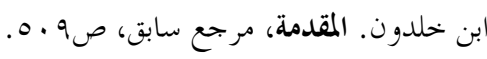

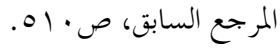




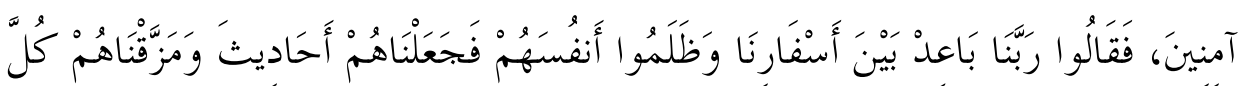

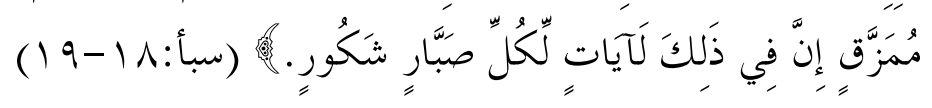

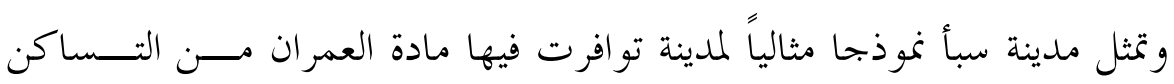

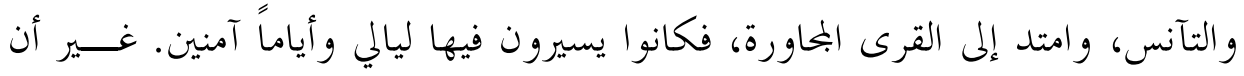

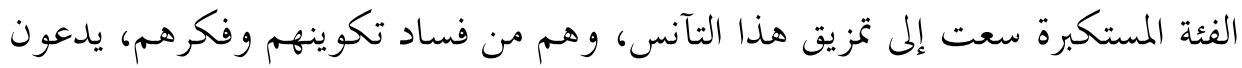

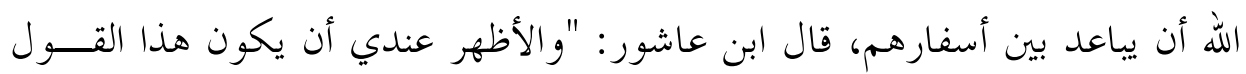

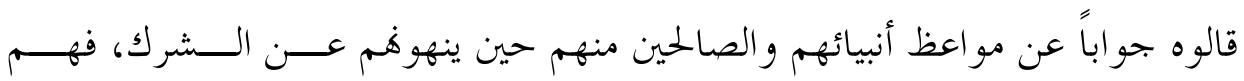

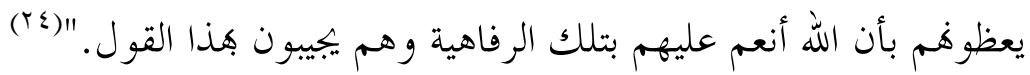

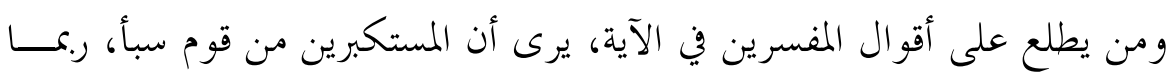

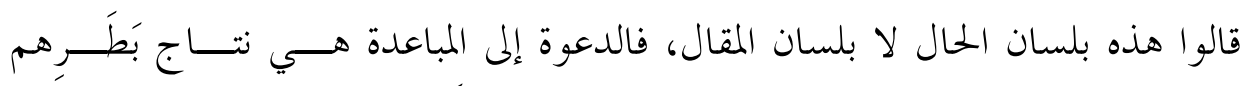

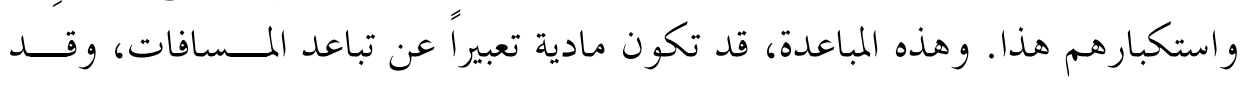

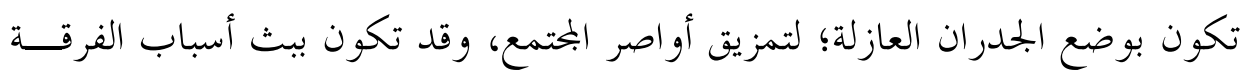
وإشاعة أسباب التباغض عبر النميمة والهمز و اللمز.

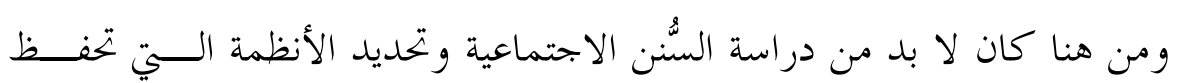
وجود الجحتمع، ومن أجلَّها النظامُ الديني.

ثالثاً: وظيفة النظام الديني في الدولة في فكرِ ابنِ خلدون:

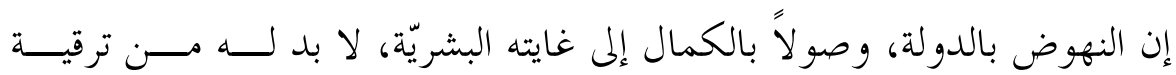

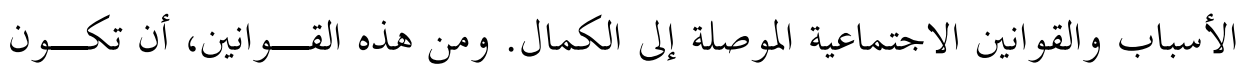

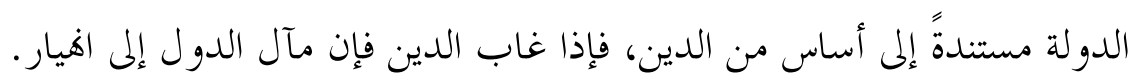

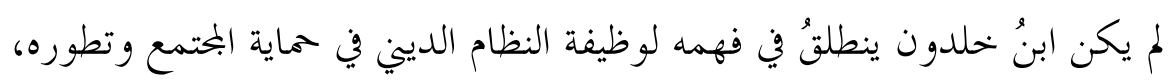

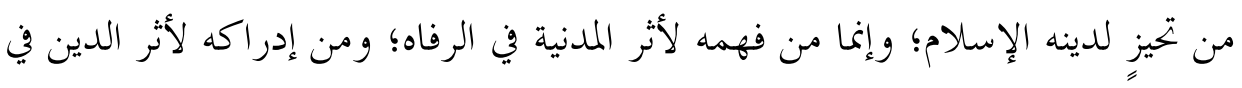




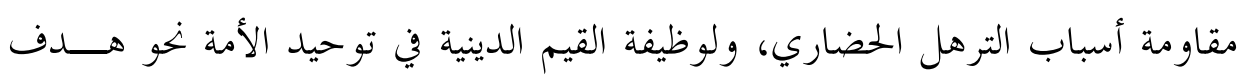
مشترك، ومحاربة أسباب التنافس السبي.

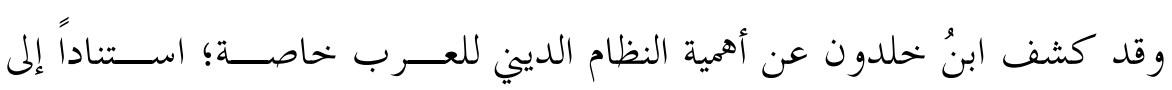

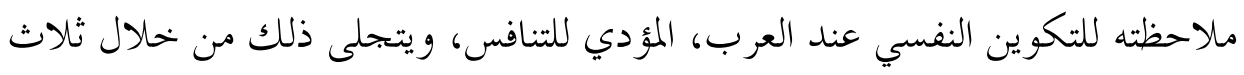

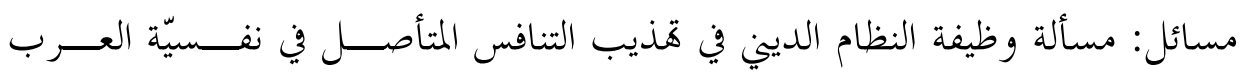

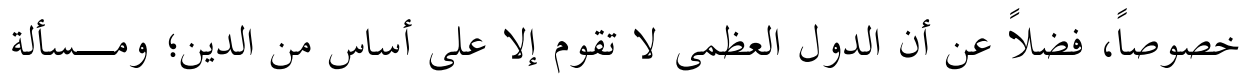

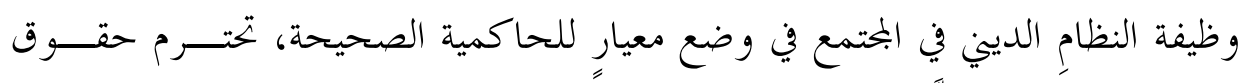

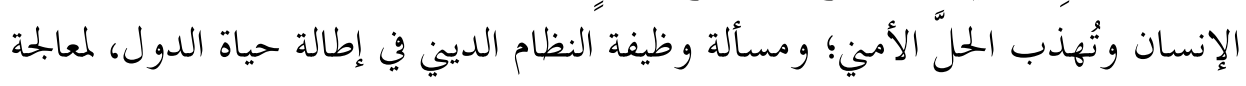

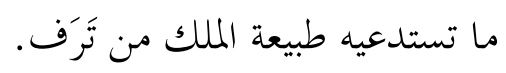

\section{المسألة الأولى: وظيفة النظام الديني في قَذيب التنافس:}

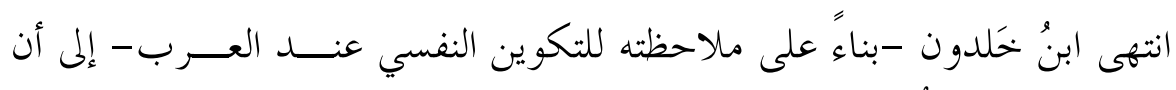

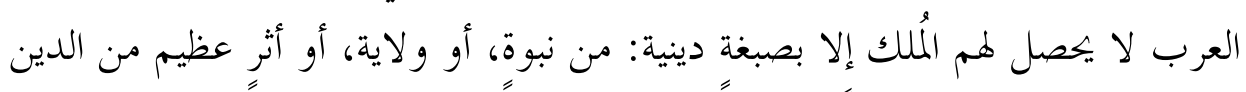

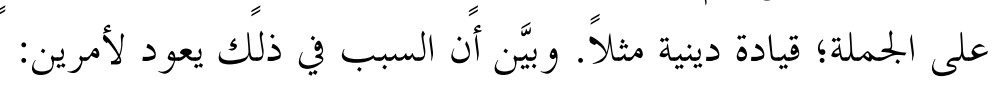

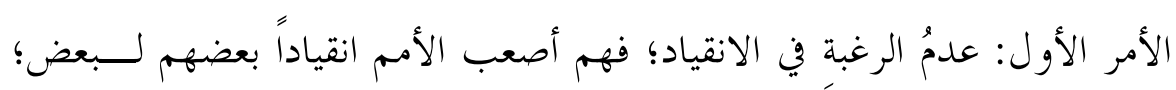

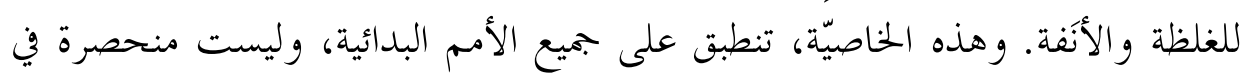

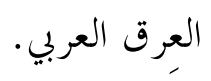

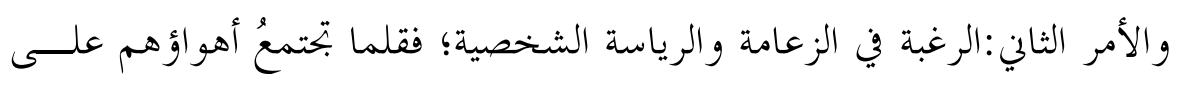

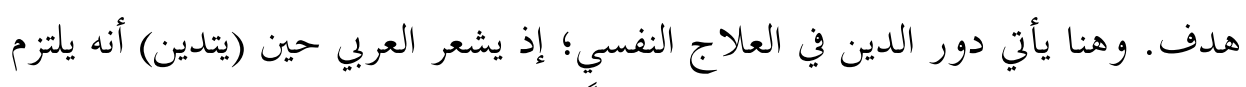

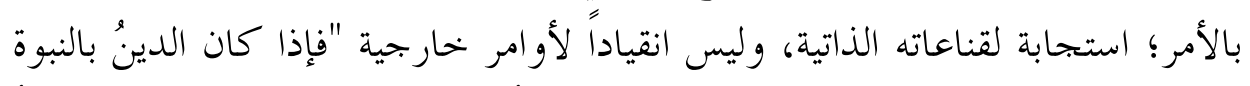

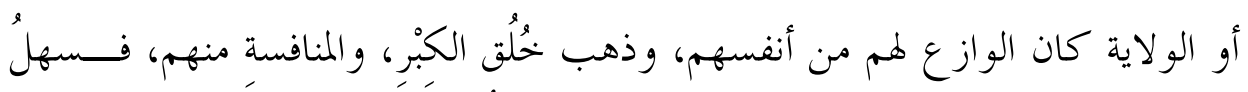

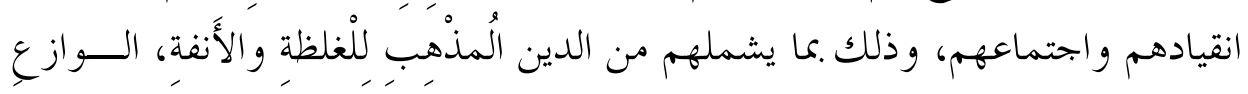

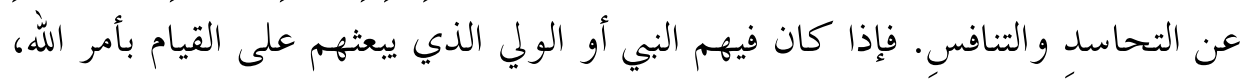

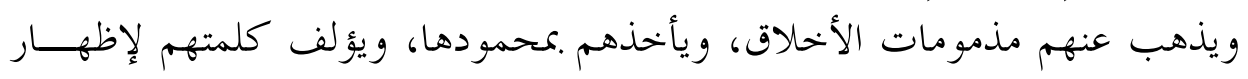




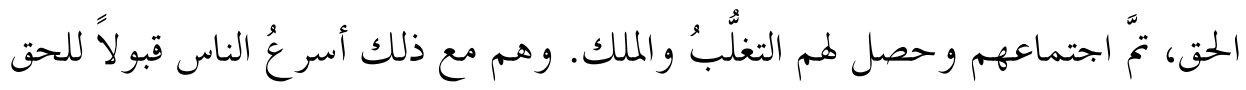

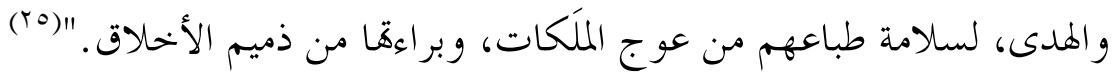
ويؤ كد نظرةً ابنِ خلدون هذه، موقفُ خالد بن الوليد رضي الله عنه، حين جاءه

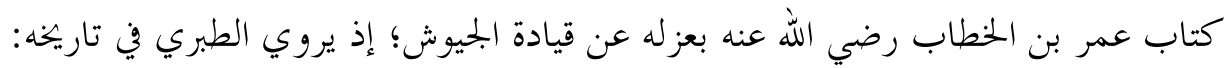

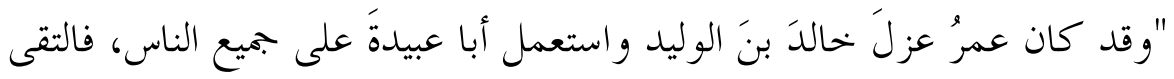

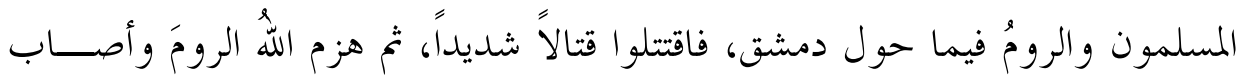

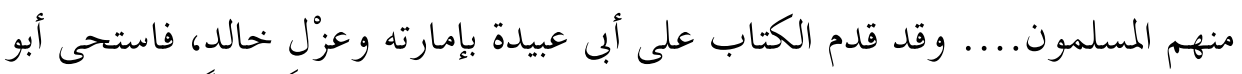

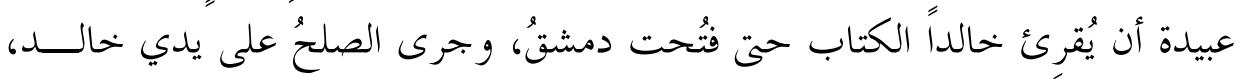

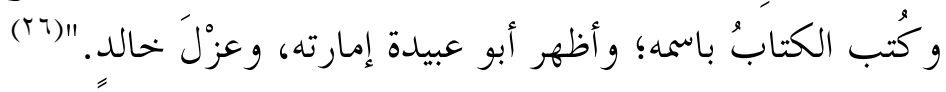

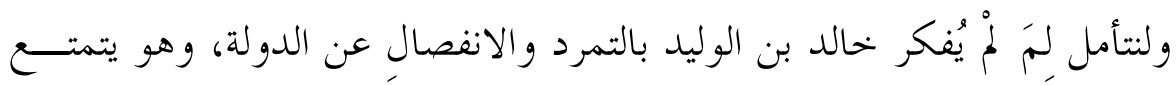

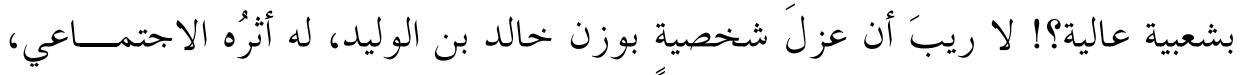

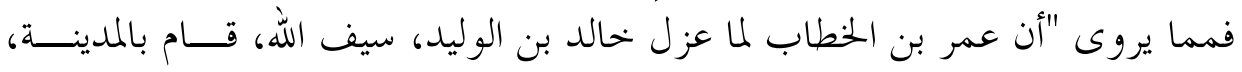

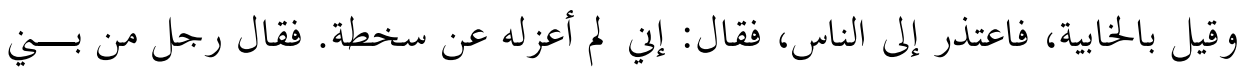

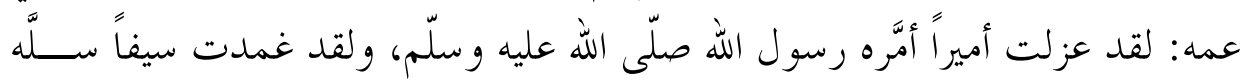

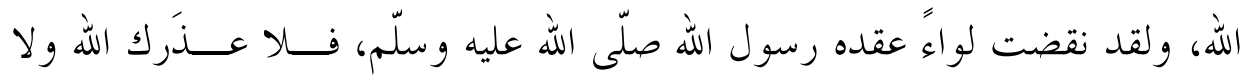

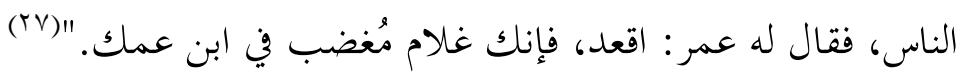
إن هذه النصوص، تنقل لنا غضبَ بحموعة من الناس من عزل خالد، ولكن القيمِ

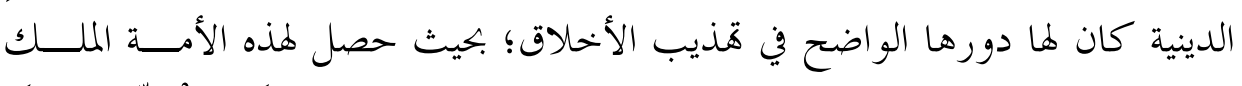

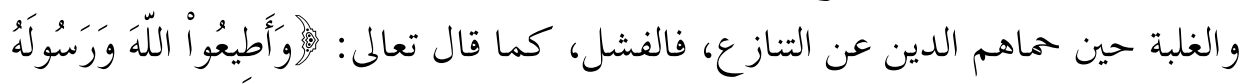

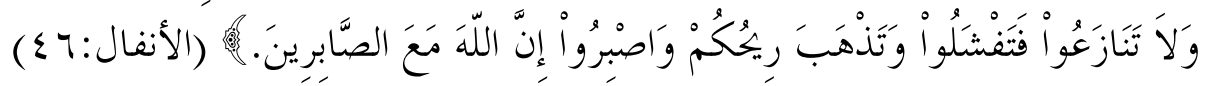

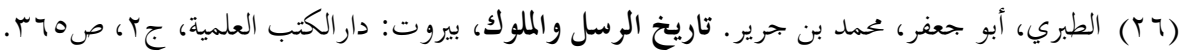

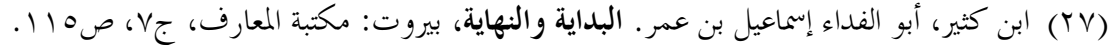




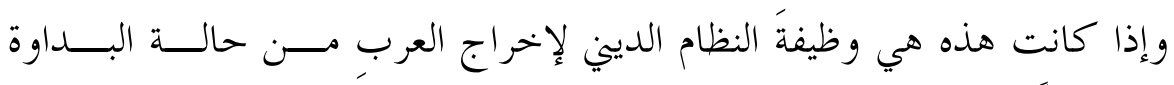

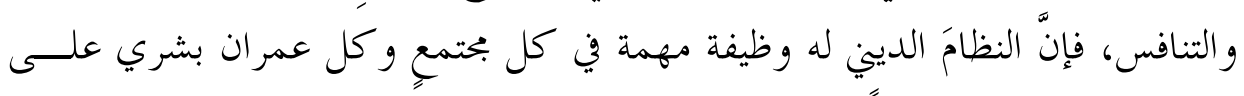

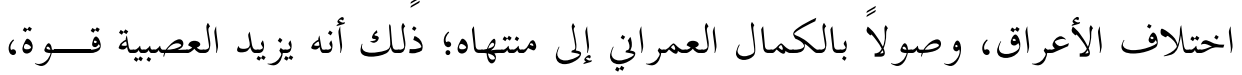

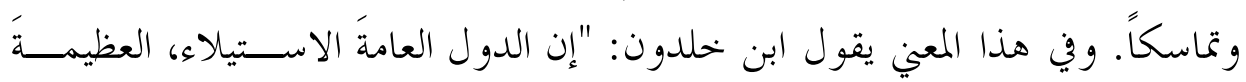

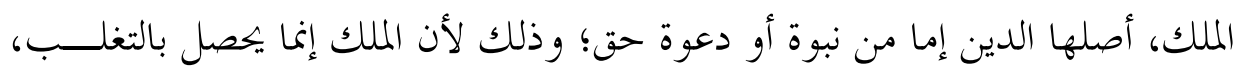

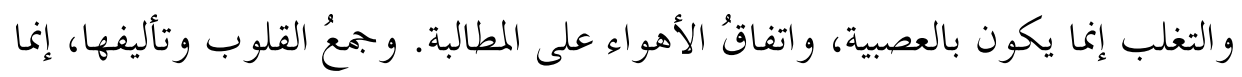

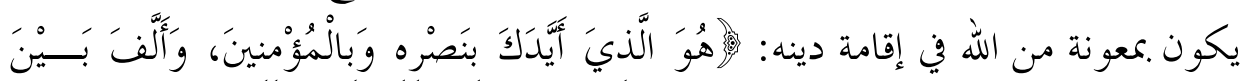

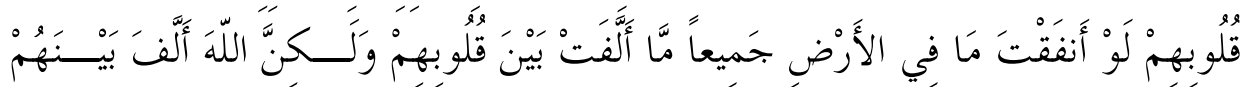

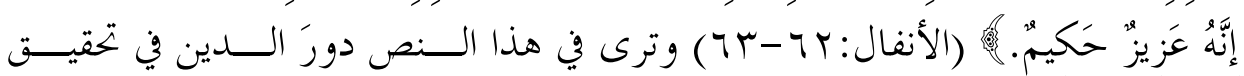

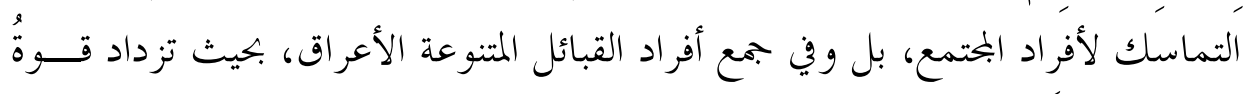

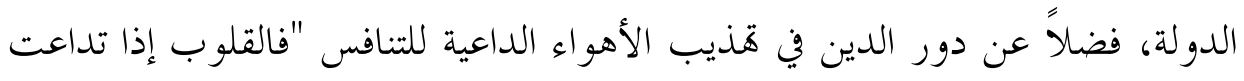

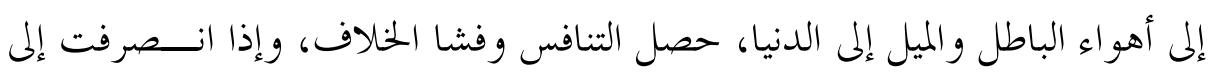

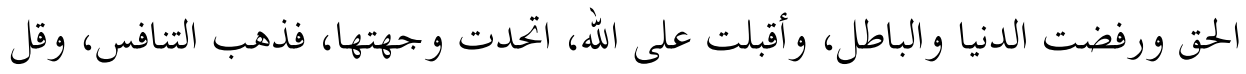

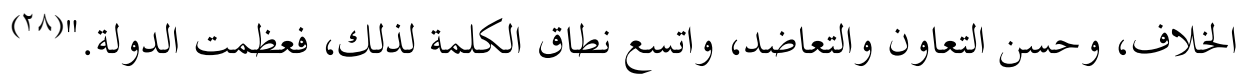

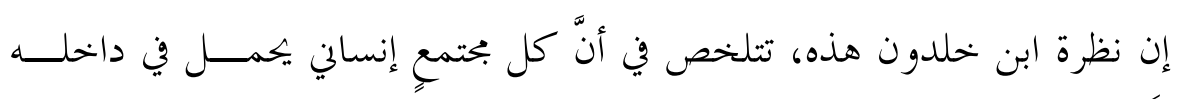

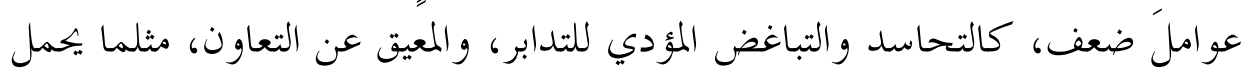

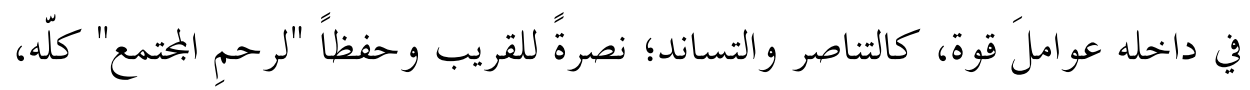

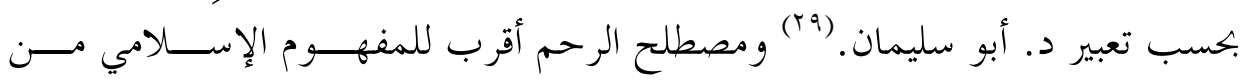

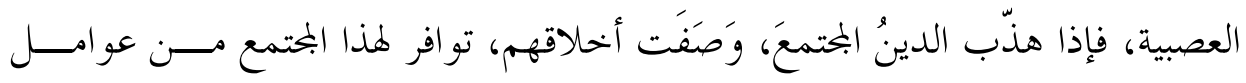

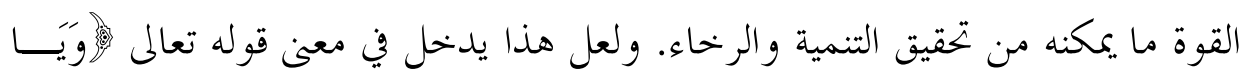

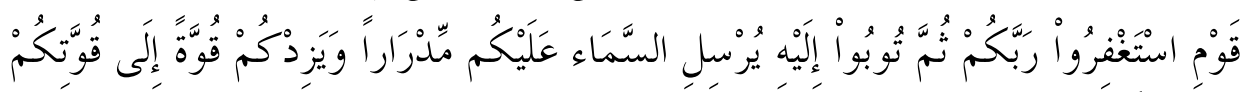

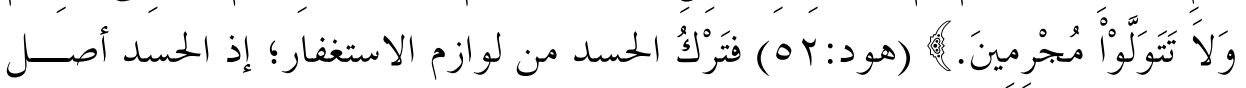

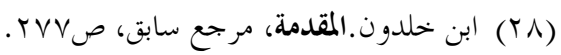

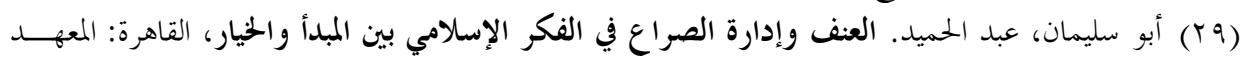

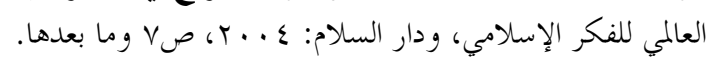


الشرور كلها، فهو سبب أول ذنب عُصي اللهّ تعالى به في السماء، وسبب أول جريمة

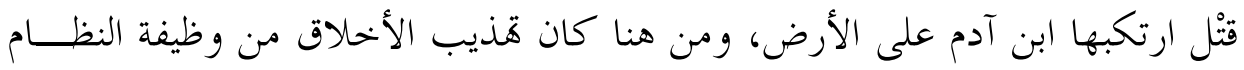

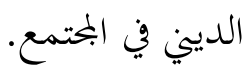

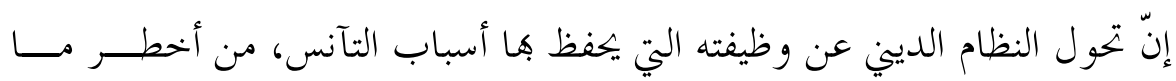

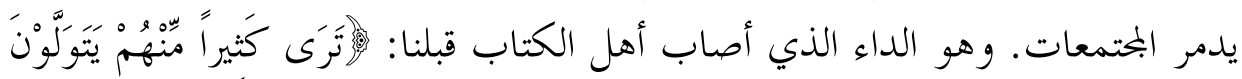

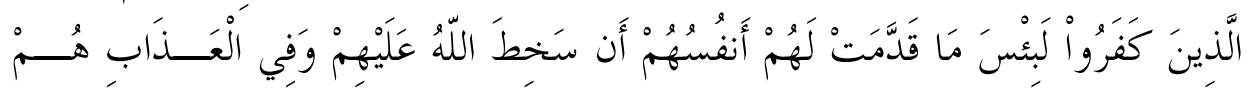

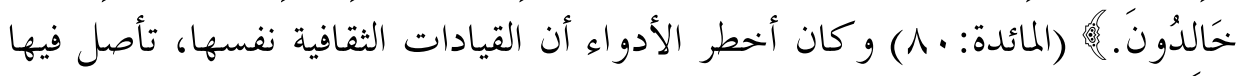

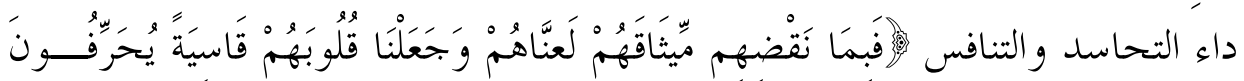

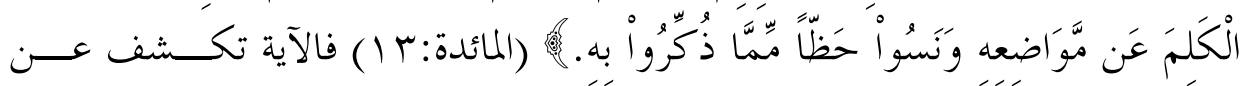

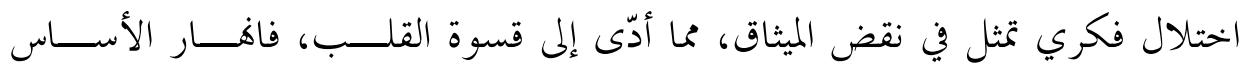

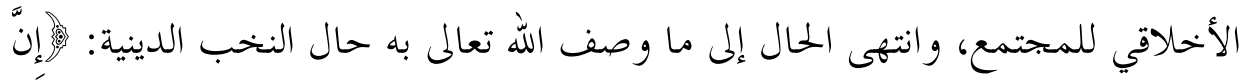

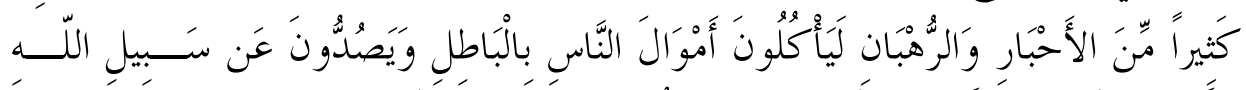

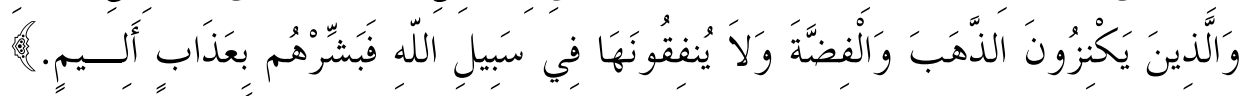

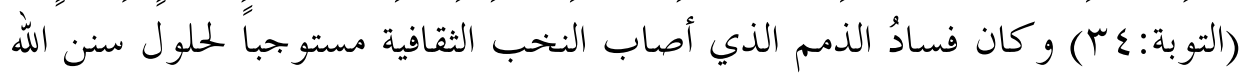

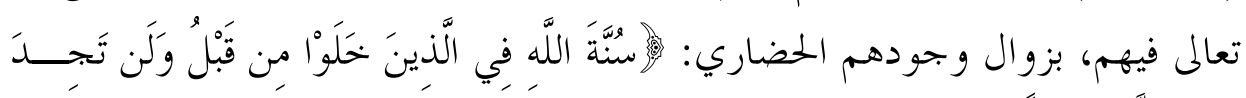

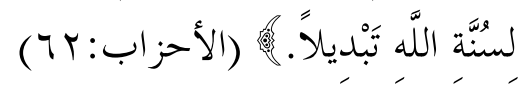

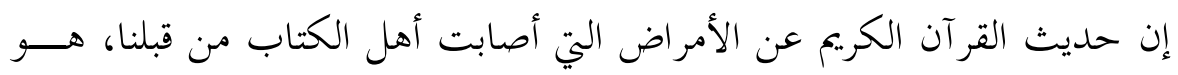

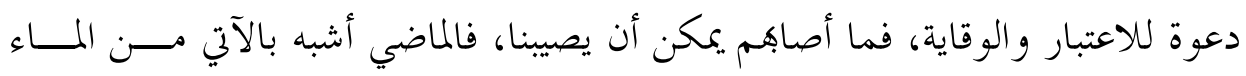
بالماء.

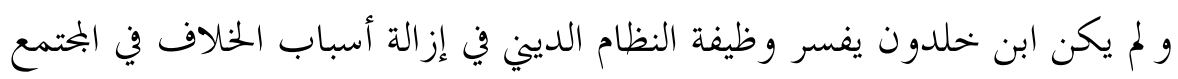

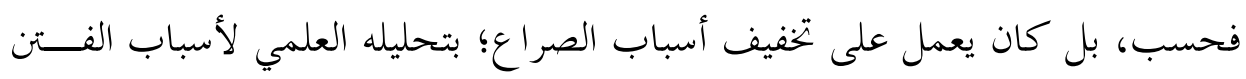

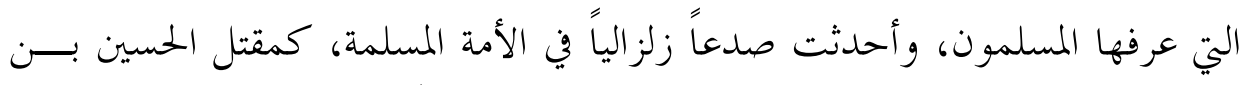

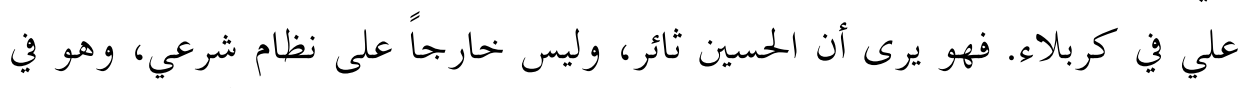

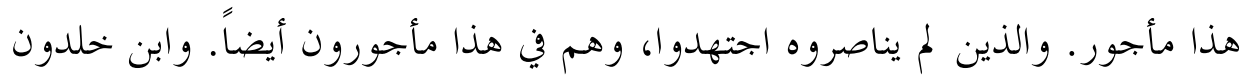




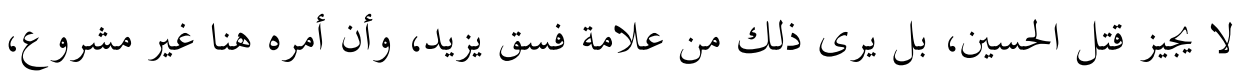

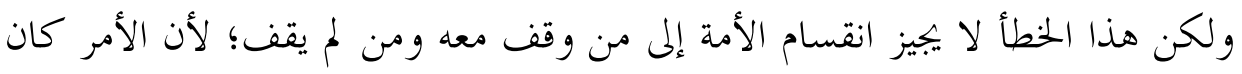

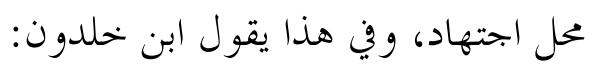

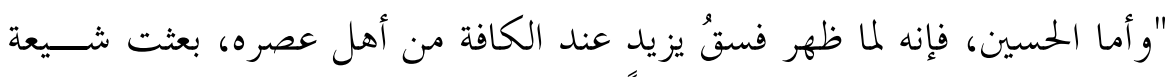

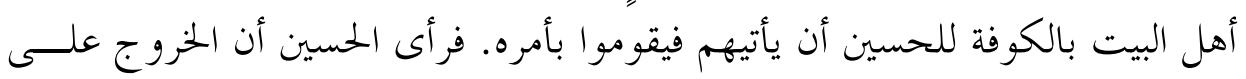

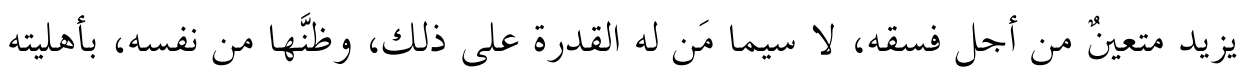

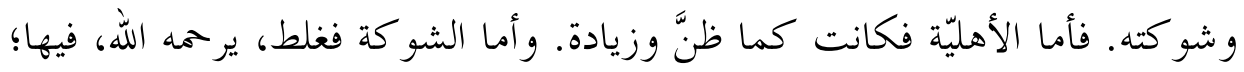

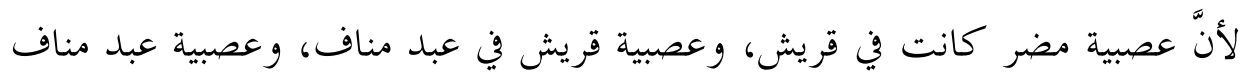

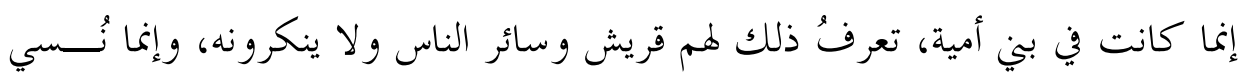

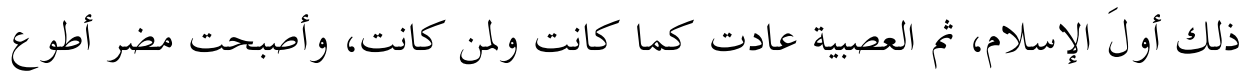

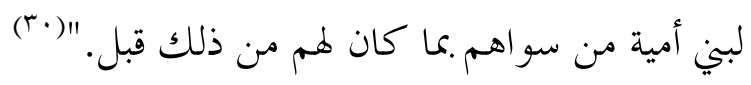

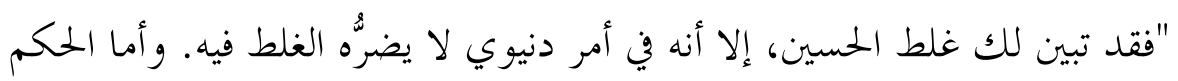

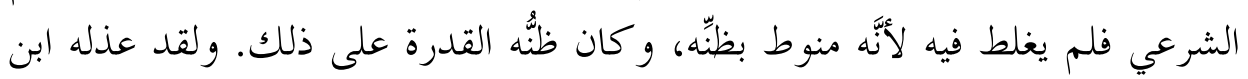

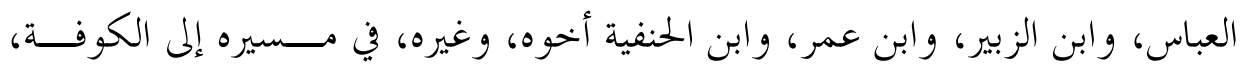

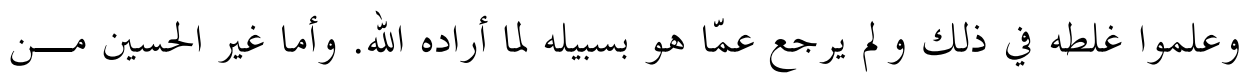

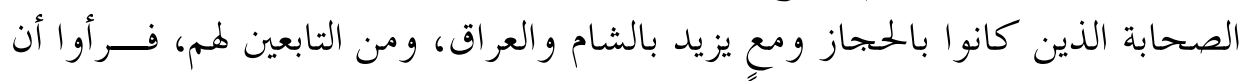

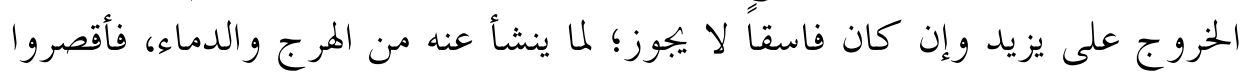

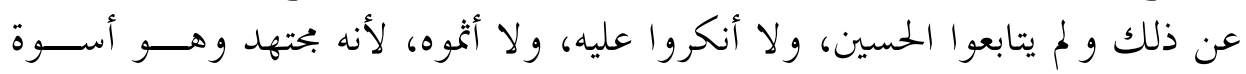

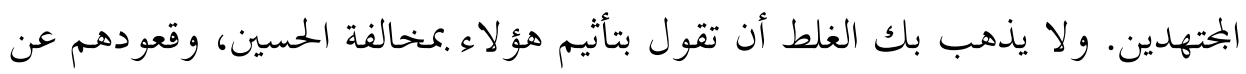

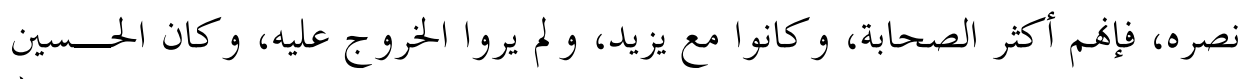

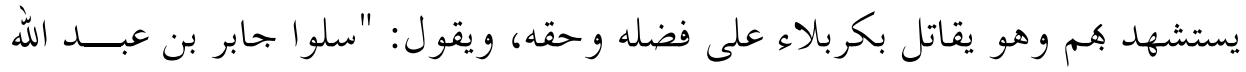

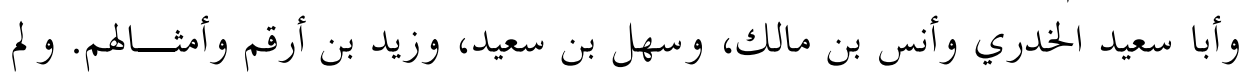

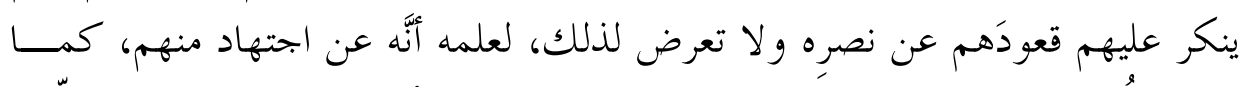

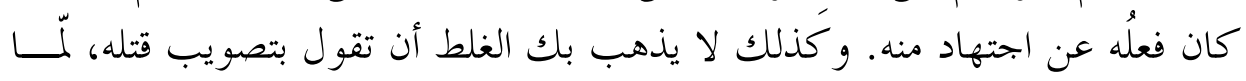


كان عن اجتهاد، وإن كان هو على اجتهاد فلا يبوز قتال الحسين مع يزيد ولا ليزيد،

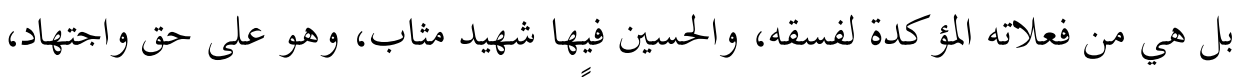

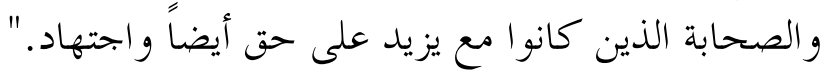

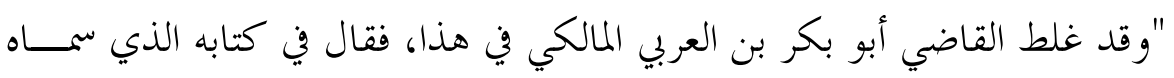

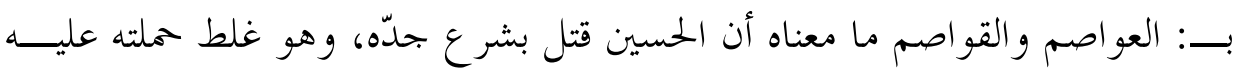

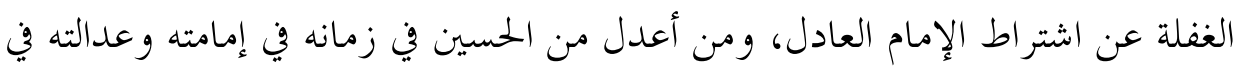

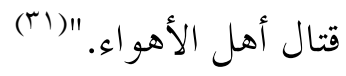

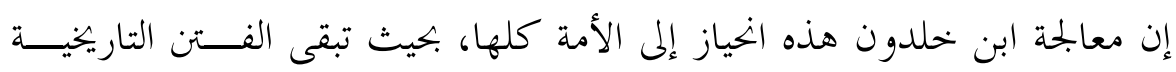

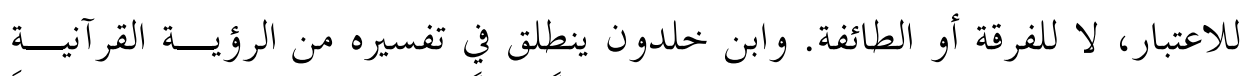

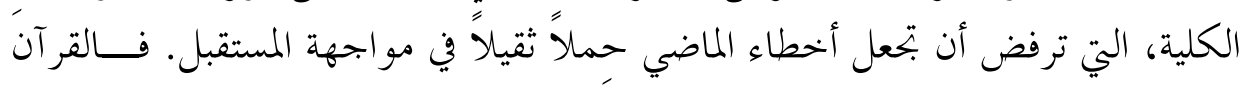

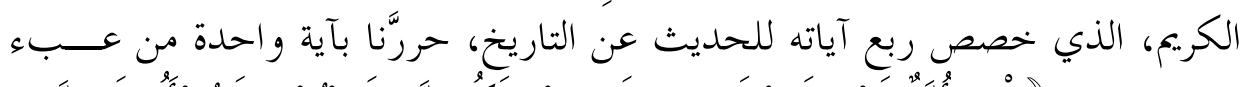

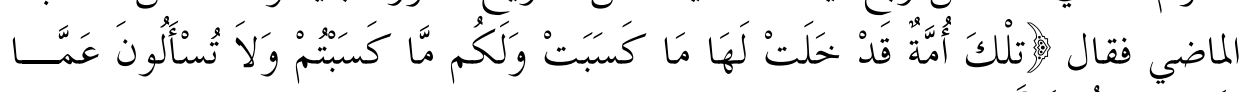

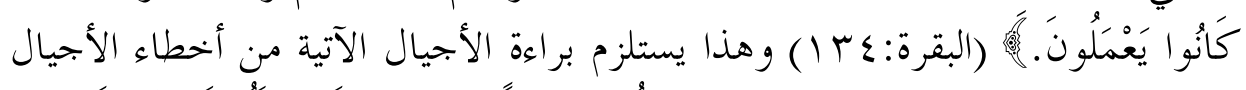

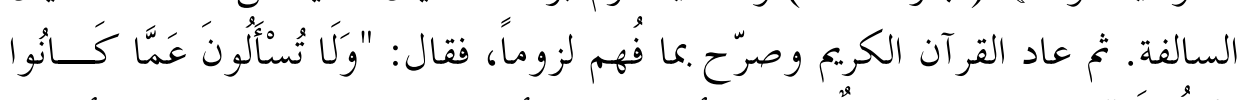

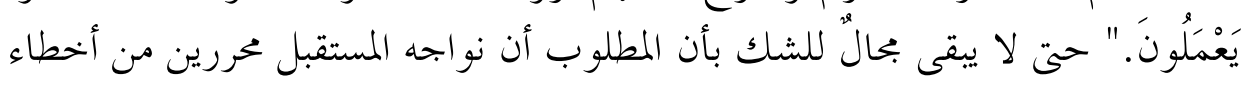

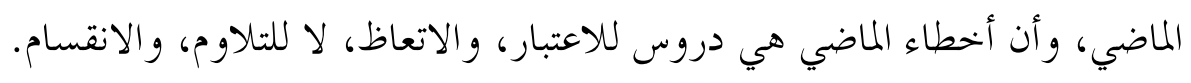

\section{المسألة الثانية: وظيفة النظامِ الديني في البجتمع في وضع معيارٍ للحاكمية:}

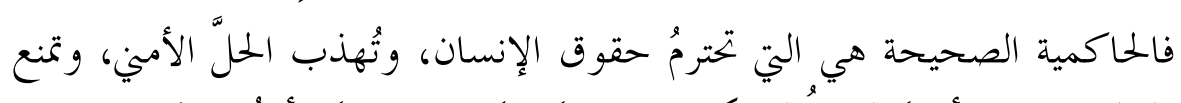

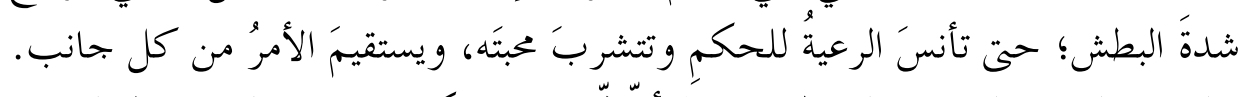

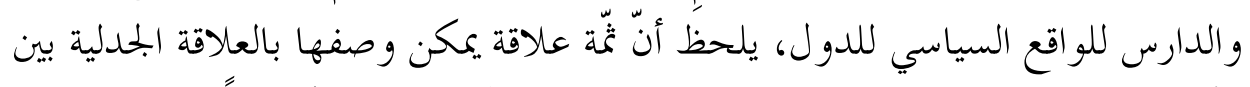

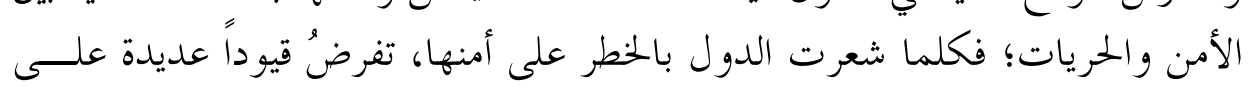

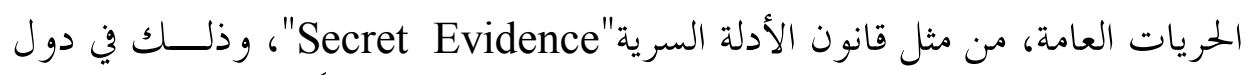

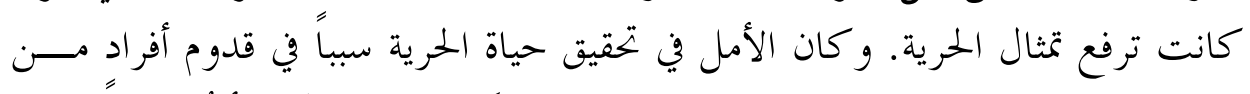

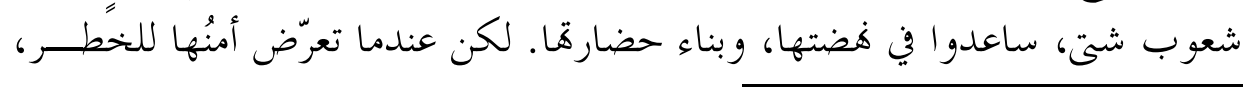

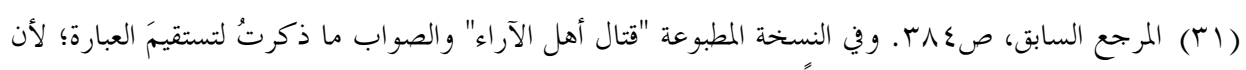

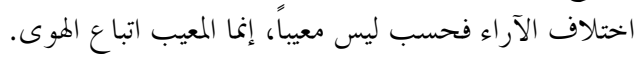


أقرّت قوانين الاعتقال من غير عرض أسباب الاعتقال على القضاء؛ استجابة لــــافع

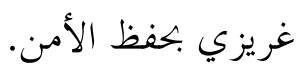

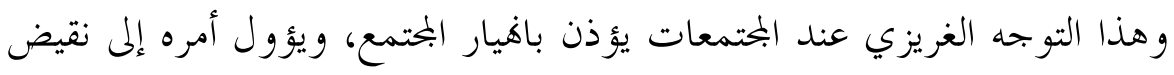

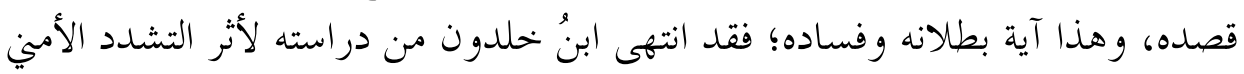

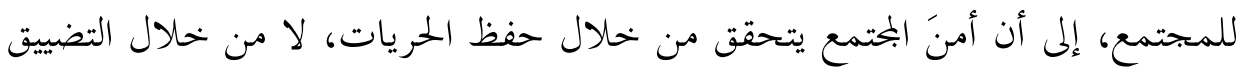
عليها، وأن مآل التشدد الأمني أفيار الدولة نفسها.

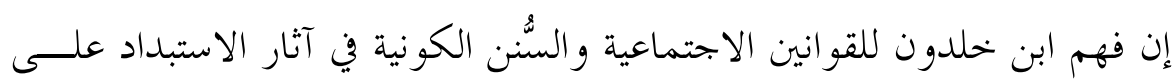

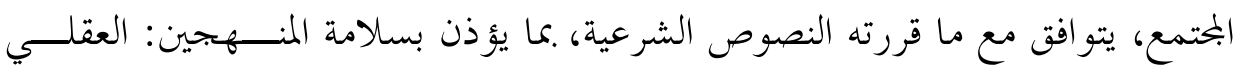

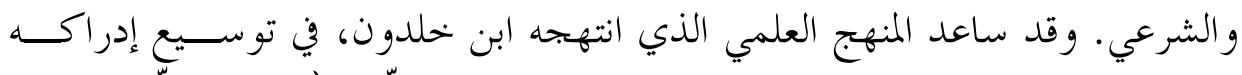

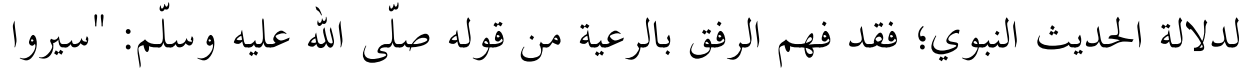

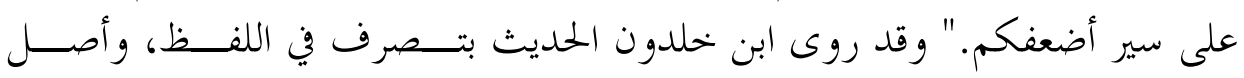

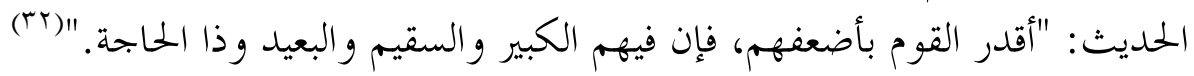

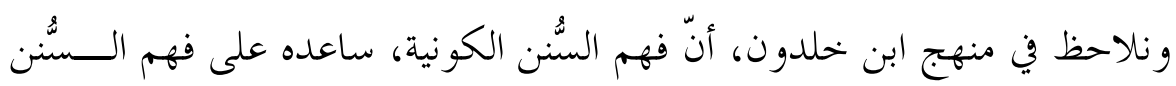

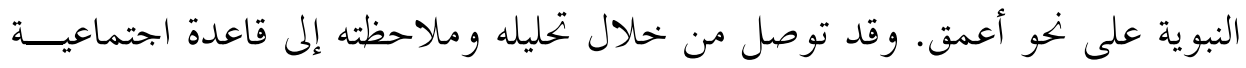

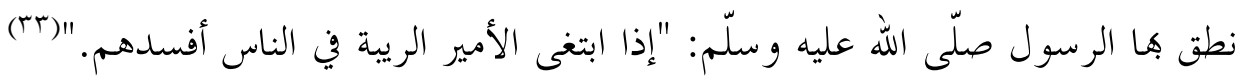

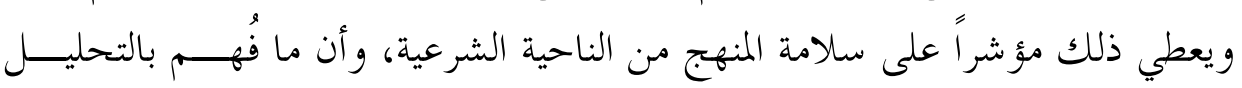

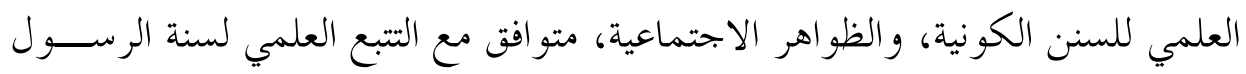
صلّى الله عليه وسلّم.

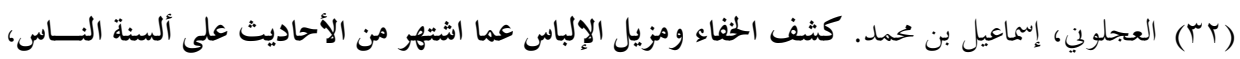

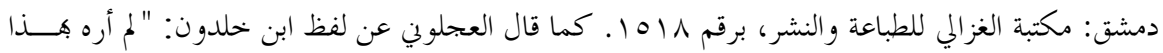

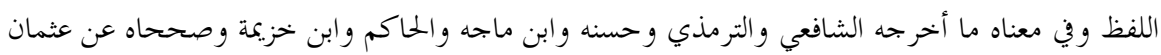

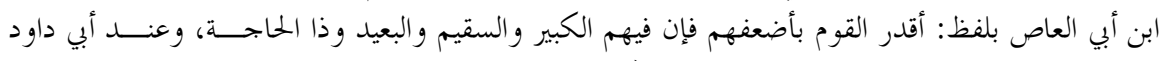

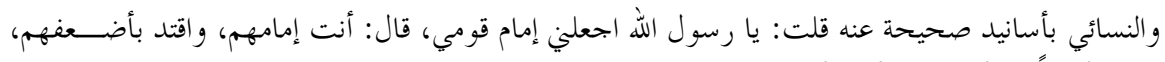

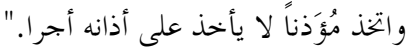

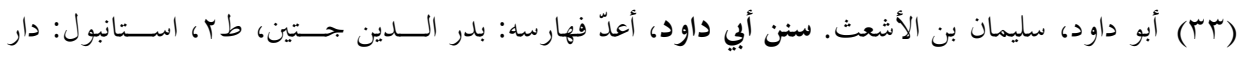

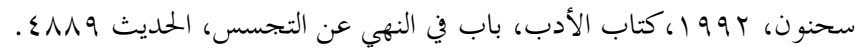


وفي هذا المعنى يقول ابن خلدون: "الملك إذا كان قاهراً، باطشاً بالعقوبات، منقباً

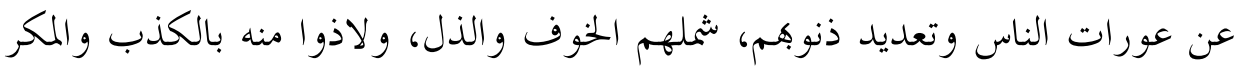

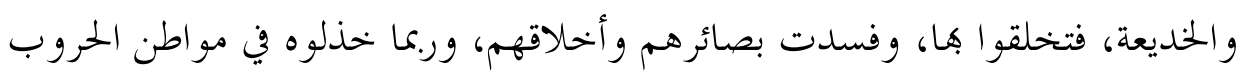

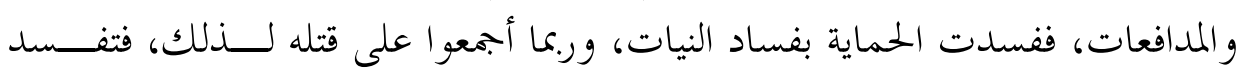

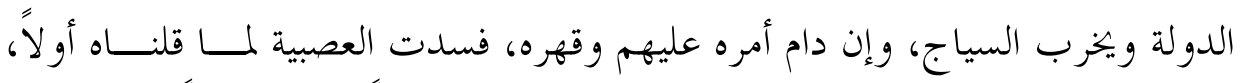

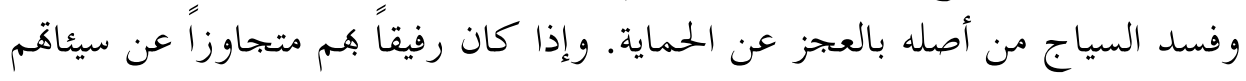

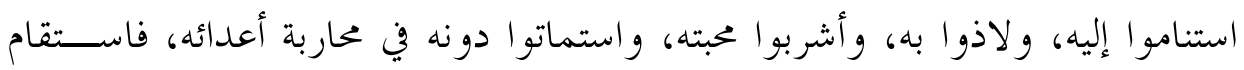

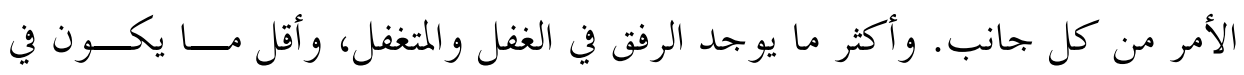

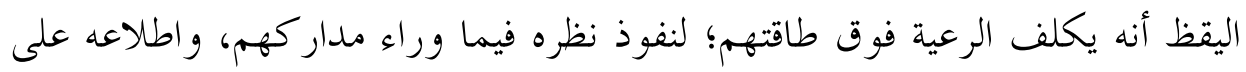

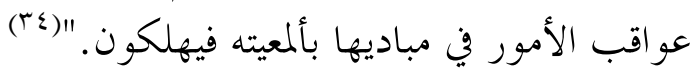

\section{المسألة الثالثة: وظيفة النظام الديني في إطالة حياة الدول:}

يوضح ابن خلدون أن طبيعة الملك تستدعي الترف، وليس غير النظام الديني سبيلاً

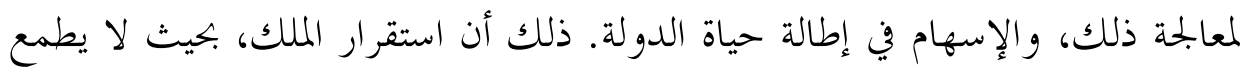

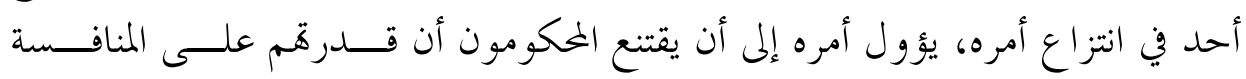

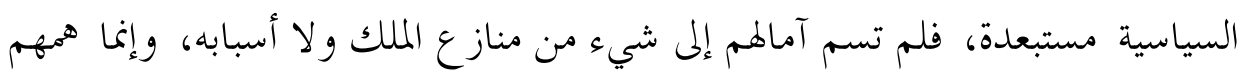

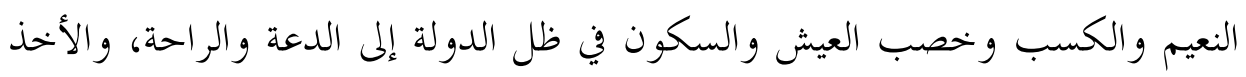

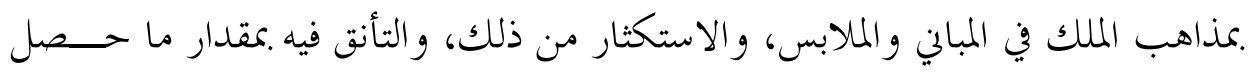

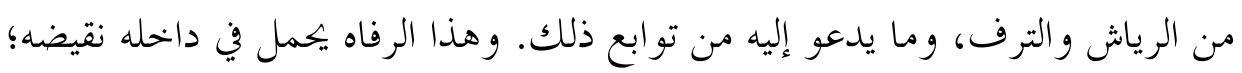

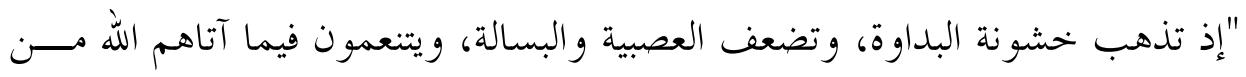

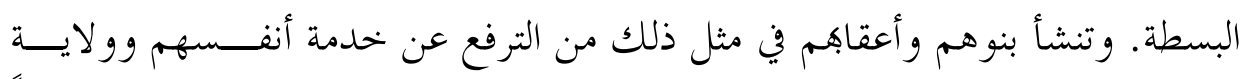

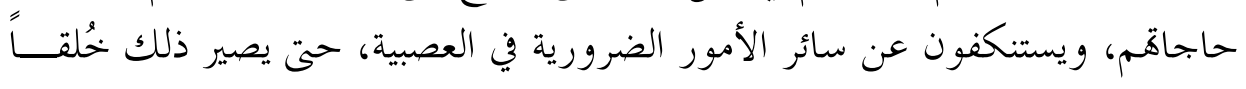

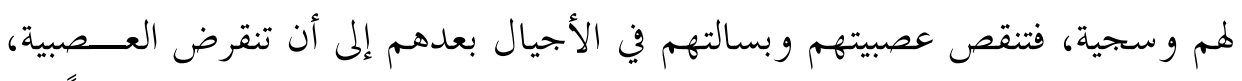

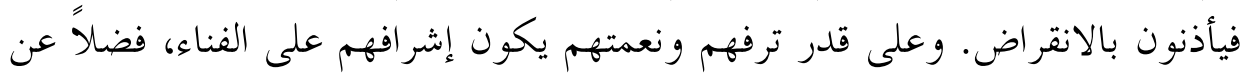

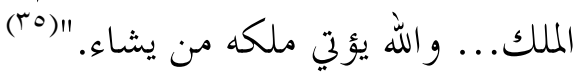




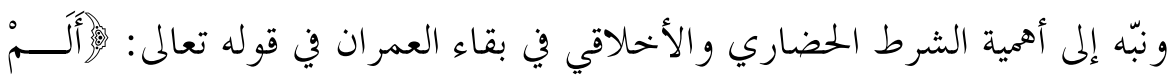

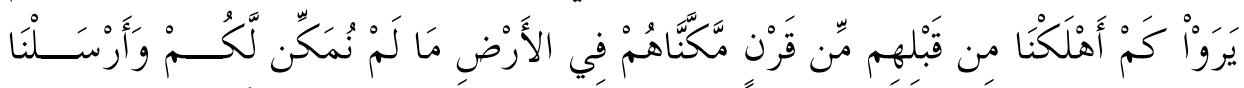

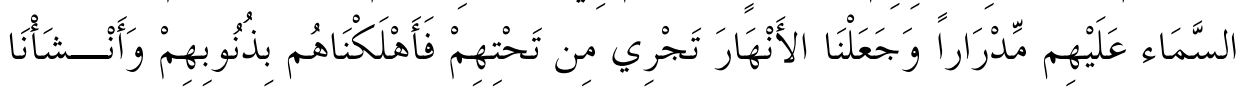

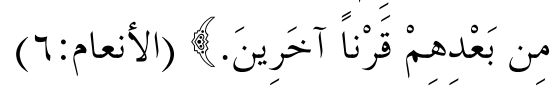

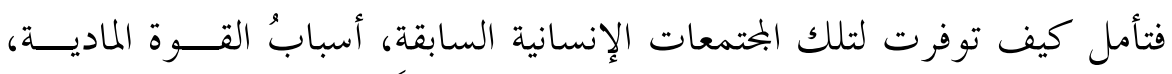

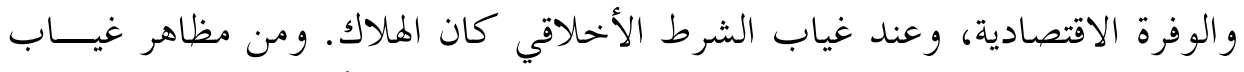

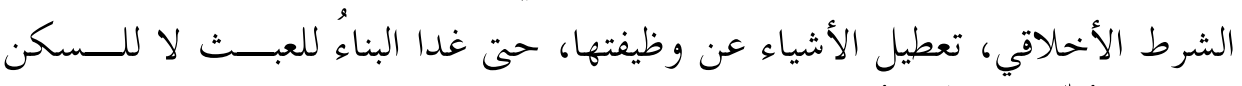

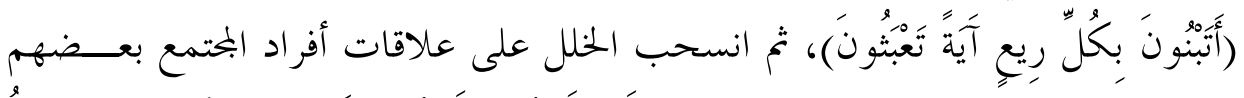

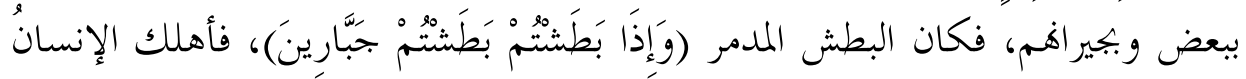

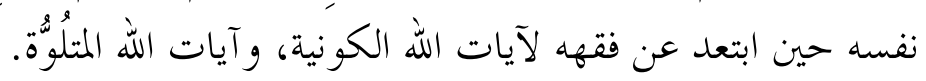
إنَّ دراسة ابن خلدون، تنطلق من فكرة "النسق الاجتماعي أو المدرسة الوظيفية"،

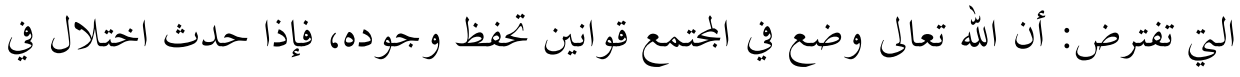

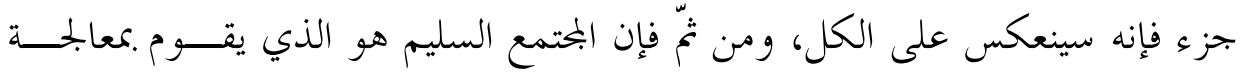

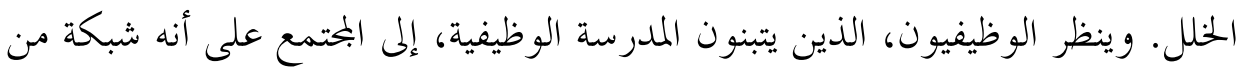

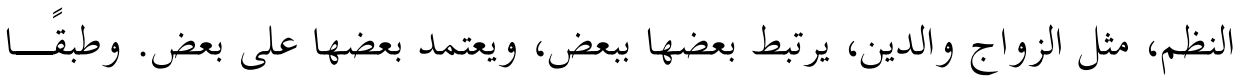

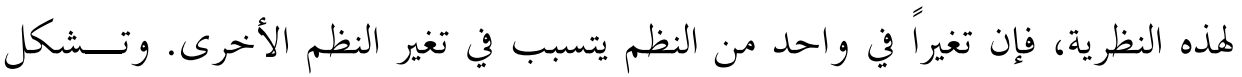

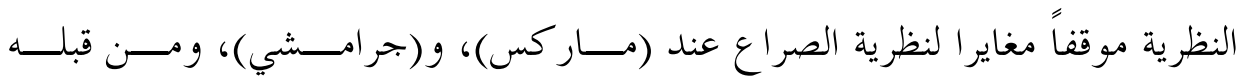
(هير (قليطس).

كما أن البحتمع ينظّم نفسه بنفسه؛ لأنه بناء متكامل. لكن هذا التنظيم، يحتاج إلى إلى

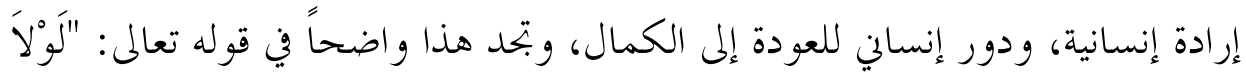

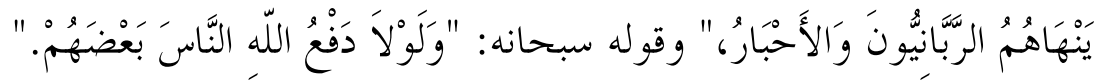

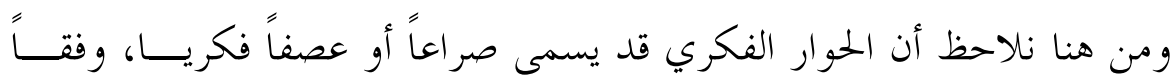

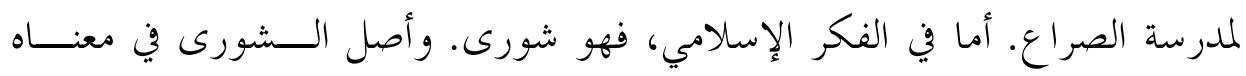




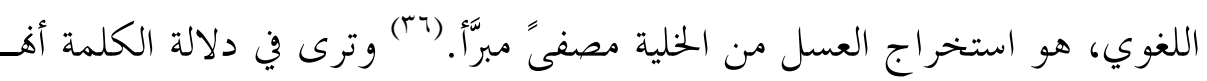
تتضمن نظرية واضحة في أن الكمال موجود، ونريد أن نصل إليه.

رابعاً: منهج ابن خلدون في فهم النص الشرعي المتعلق بالموضوع الاجتماعي:

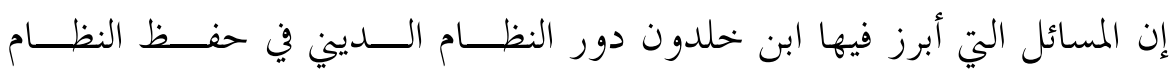

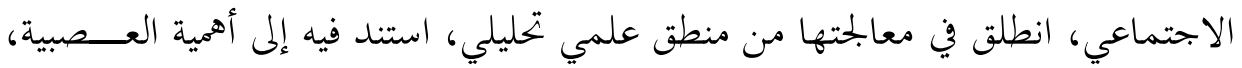

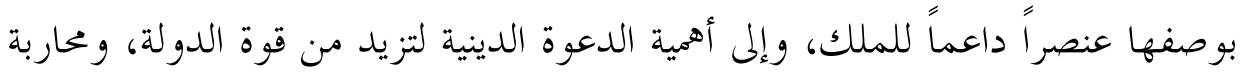

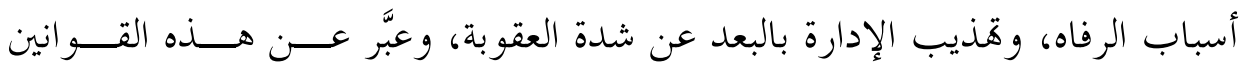

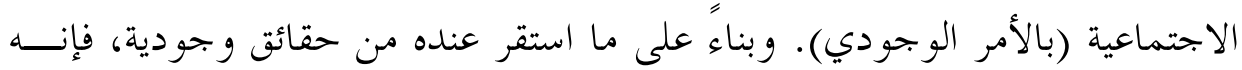

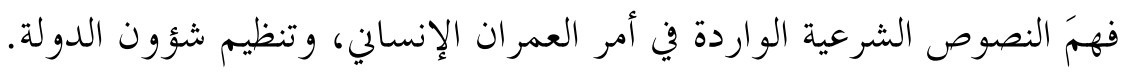

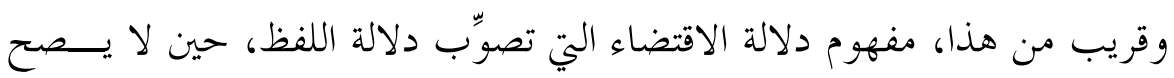

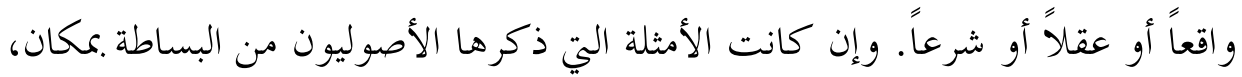

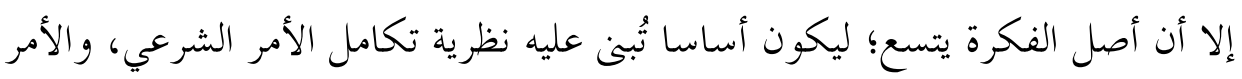

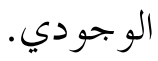

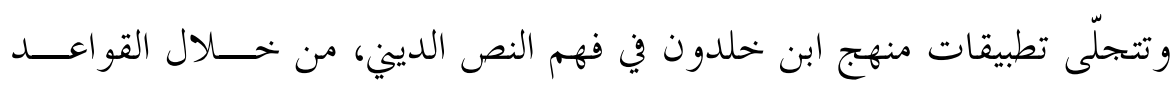
الاجتماعية، في عدد من المسائل منها:

\section{1. العصبية هي الاستطاعة على تغيير المنكر:}

فقد تو صل ابن خلدون إلى قاعدة اجتماعية هي: أن الدعوة الدينية من غير عصبية

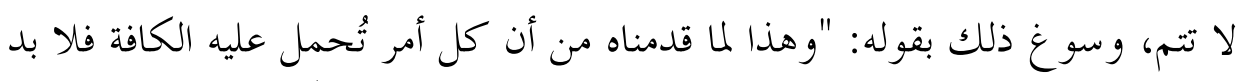

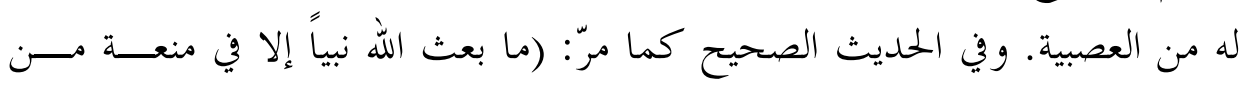


قومه.) ("v) وإذا كان هذا في الأنبياء، وهم أولى الناس بخرق العو ائد، فما ظنك بغيرهم

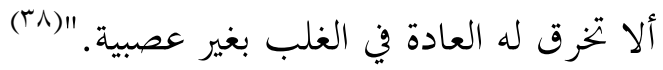

وبناء عليه، فهو يرى أن الثوار القائمين بتغيير المنكر من العامة والفقهاء، ولو كثر

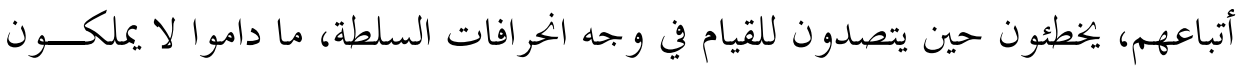

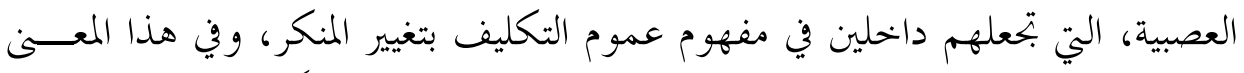

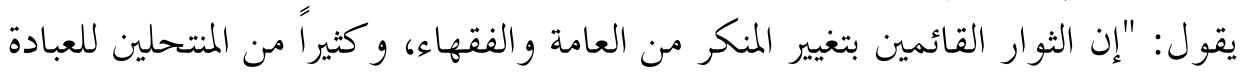

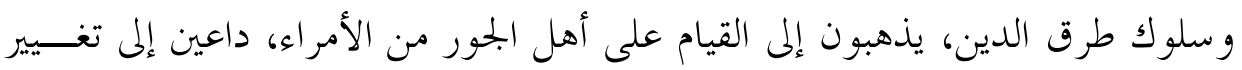

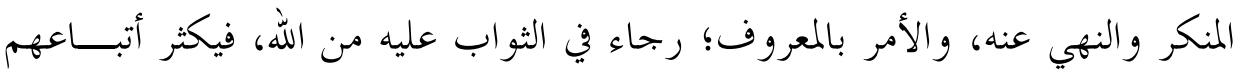

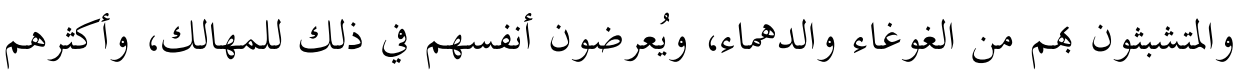

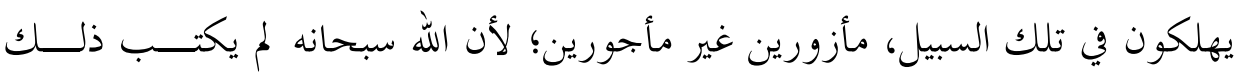

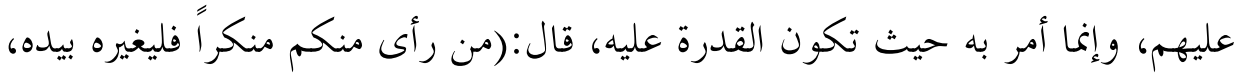

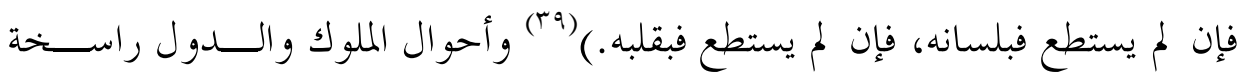

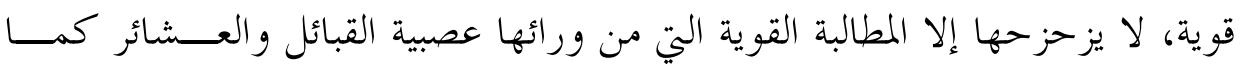

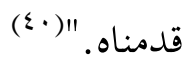

تلاحظ أن ابن خلدون يفهم دلالة (الاستطاعة) الواردة في حديث درجات تغيير

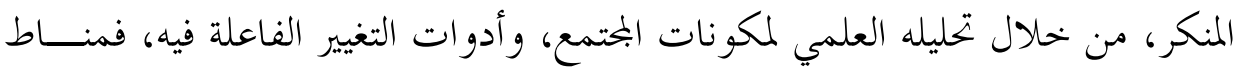

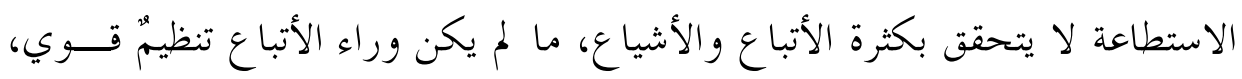
ورابطة تدفعهم للتناصر، وهو الذي عبَّر عنه بالعصبية.

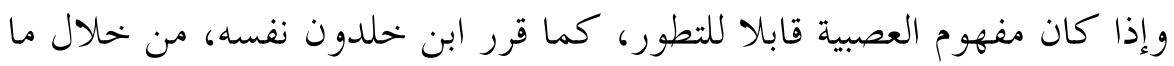

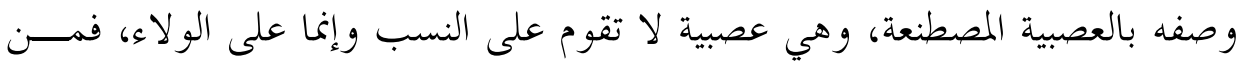
الممكن اعتبار الحزب السياسي شكلاً من أشكال العصبية.

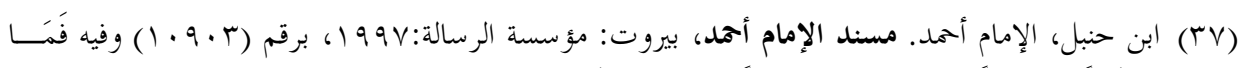

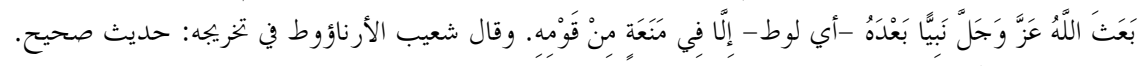

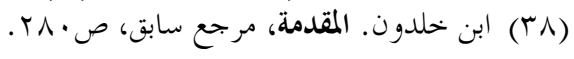

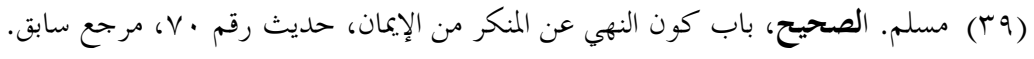

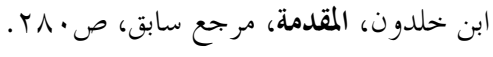


إن نظر ابن خلدون لمناط تغيير المنكر باليد، وربطه بمن امتلك العصبية، واستنكاره

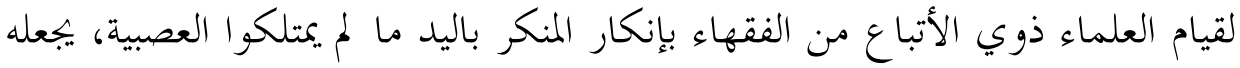
يقترب من تقسيم وظائف النظم الاجتماعية في الدراسات الحديثة. فهو يفرّق بــين:

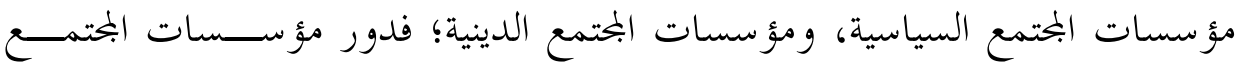

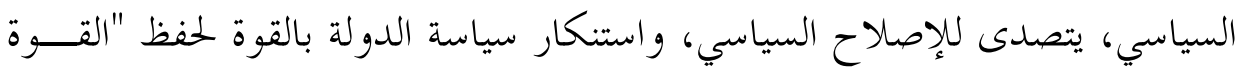

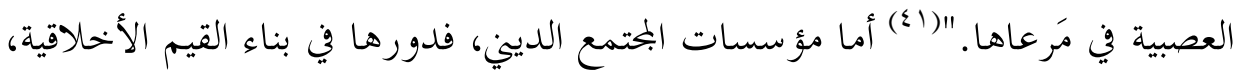

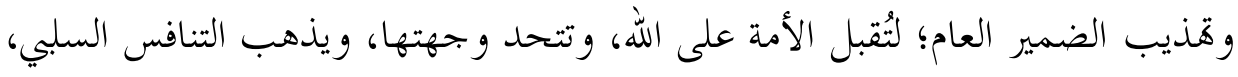

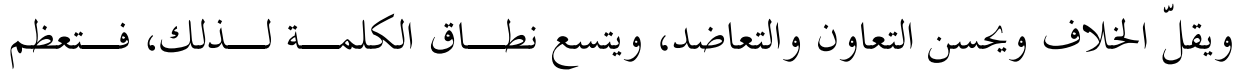
الدولة. (2r)

على أن قول ابن خلدون، بحصر مناط الاستطاعة لتغيير المنكر باليد بمسن يملــك

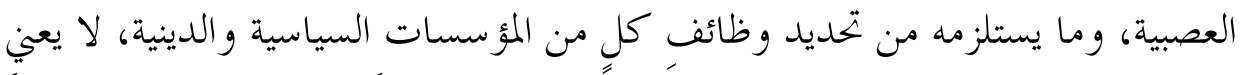

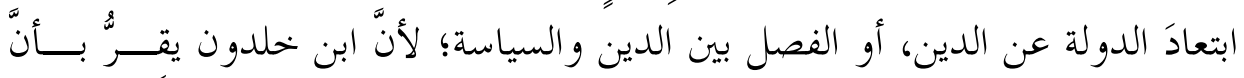

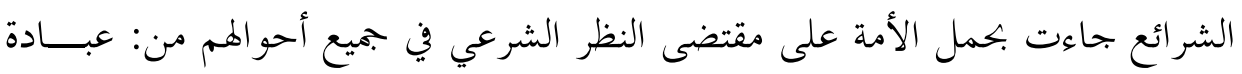

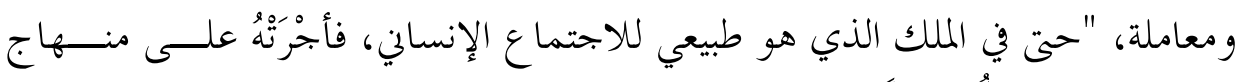

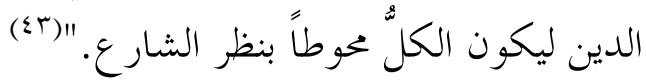

كما يقرّ بأن الدولة التي تحكم بشرع الله تعالى، هي خير أنواع الدول؛ إذ يقول:

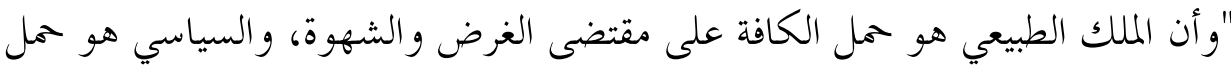

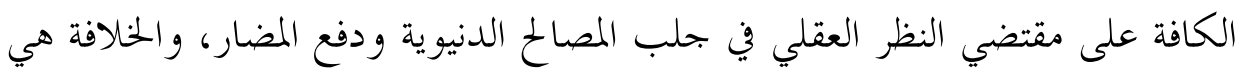

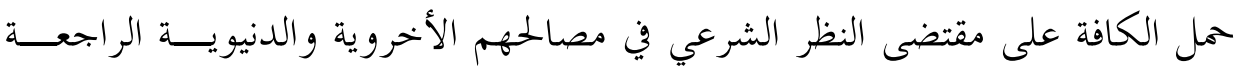

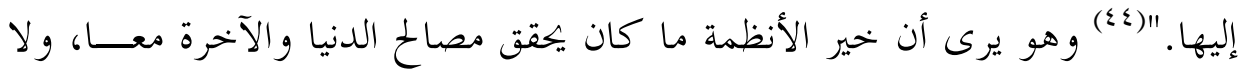

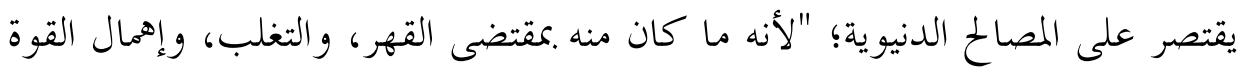




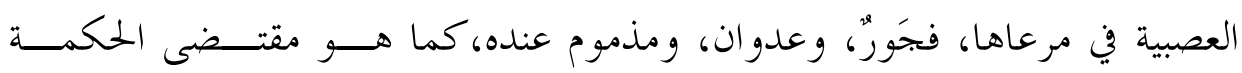

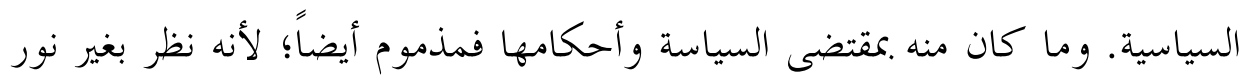

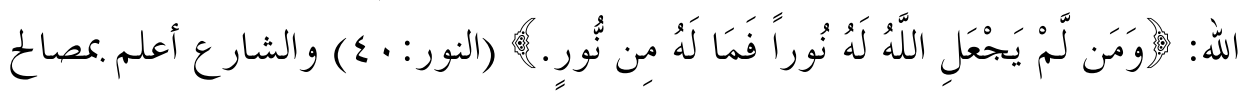

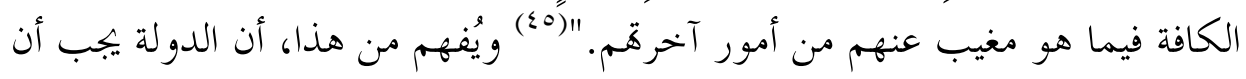

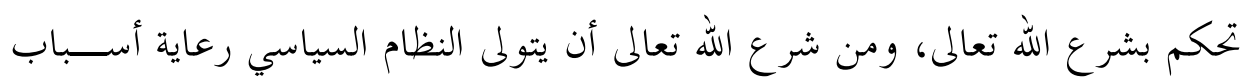

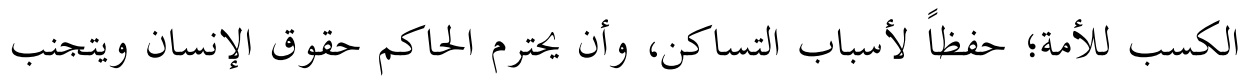

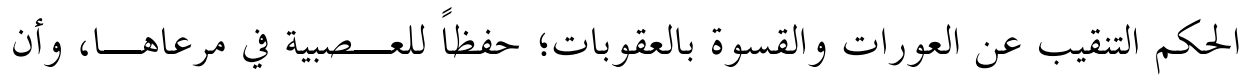

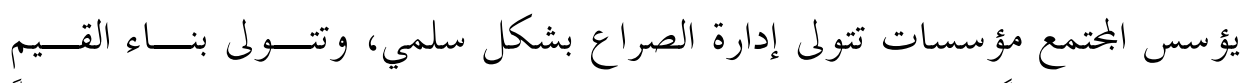

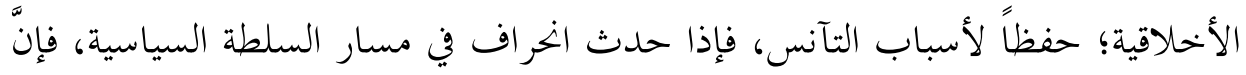

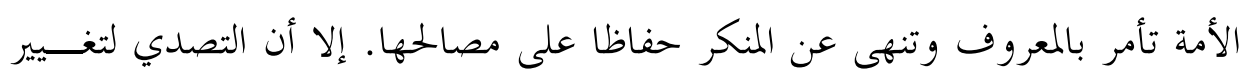

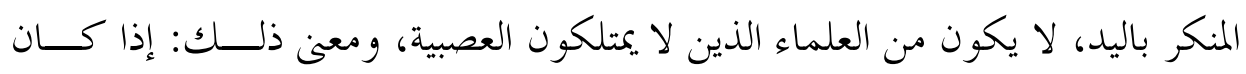

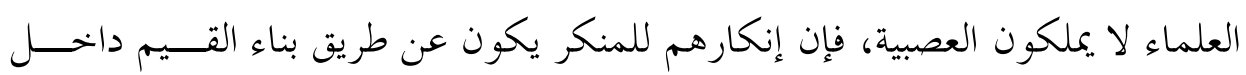

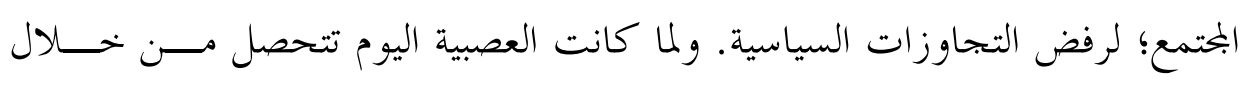

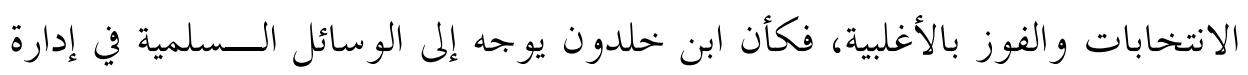
الصراع، التي تحمي الأمة من إراقة الدماء.

\section{Y. r حديث "الأئمة من قريش" وما يتضمنه من منهجية معرفية:}

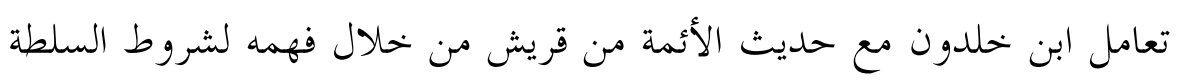

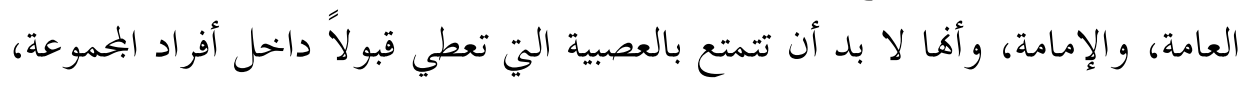

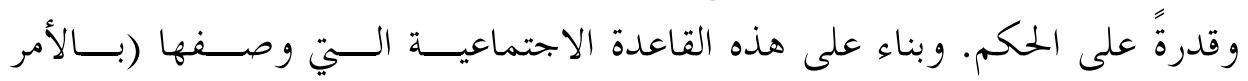

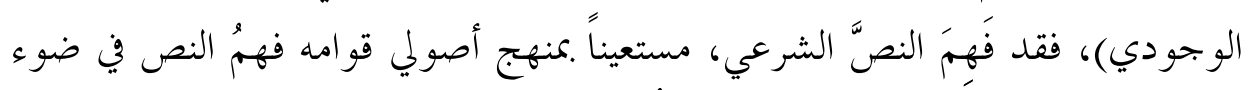

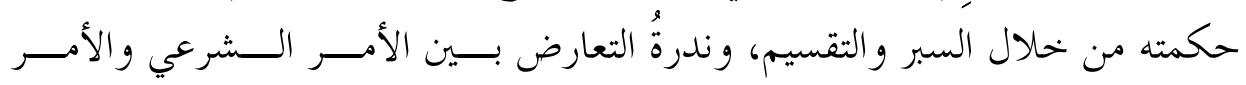
الوجودي. 
وقد اشترط جمهورُ فقهاء أهل السُّنة، والشيعة، وبعض المعتزلة، النسبَ القرشي في

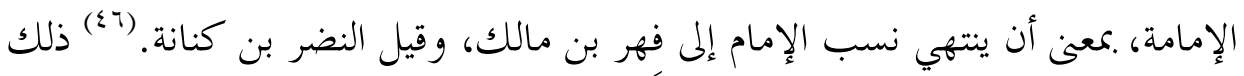

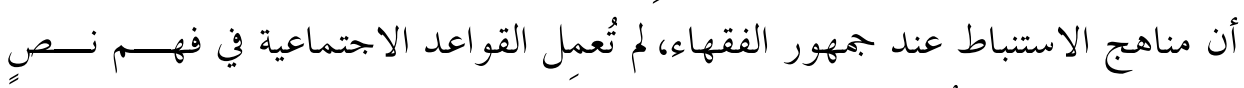

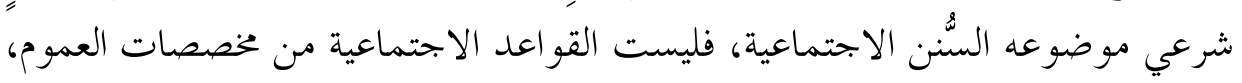

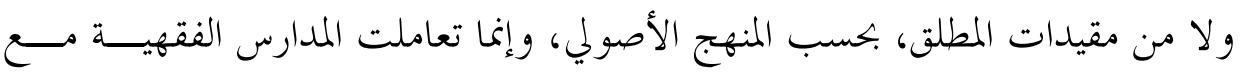

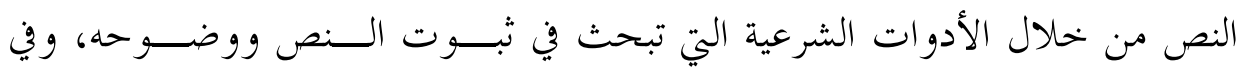
المخصصات المعروفة في باب البيان عند الأصوليين.

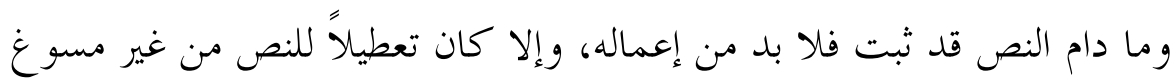

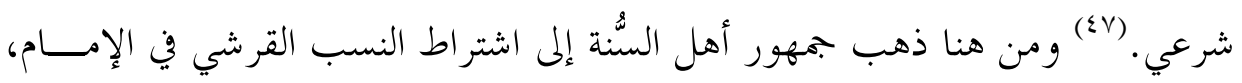

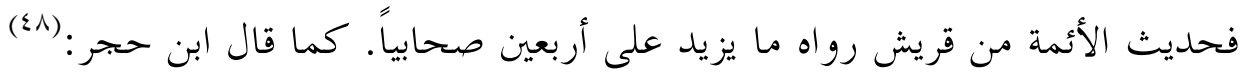

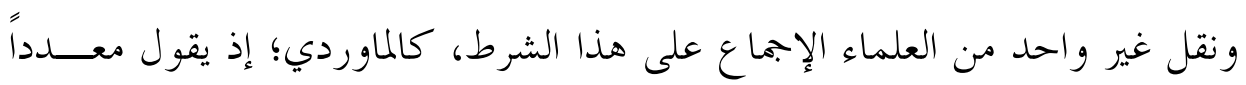

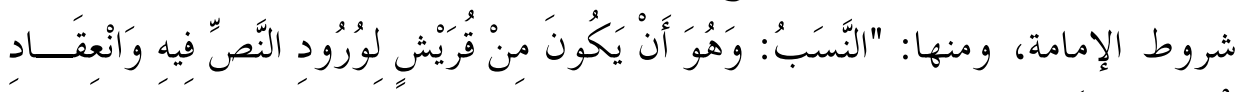

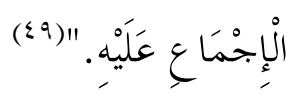

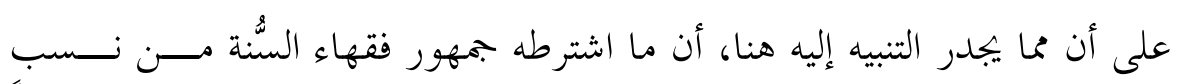

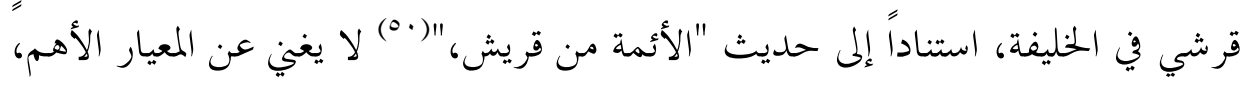

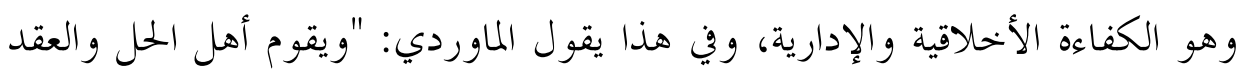

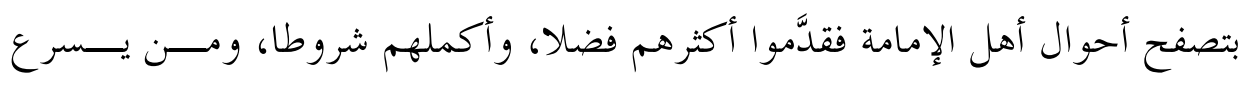

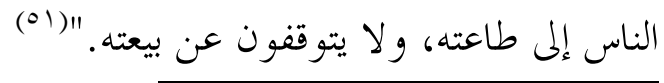

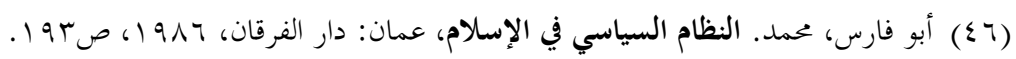

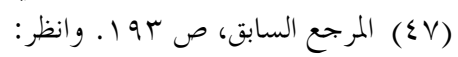
- القاضي عدالجبار الهمذاني. المغني في أبواب التوحيد والعدل، بيروت: دار إحياء التراث العربي، ج.r، المان.

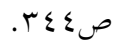

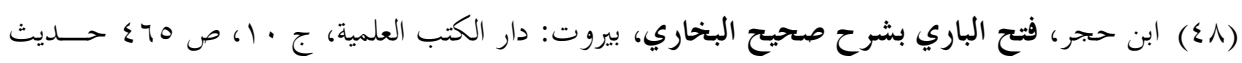

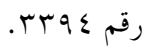

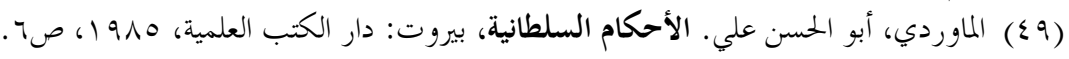

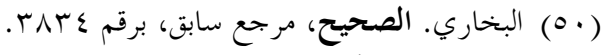

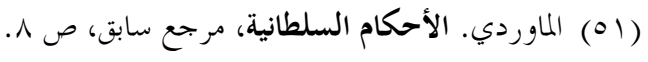




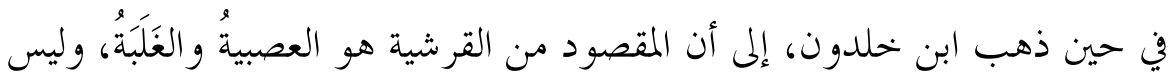

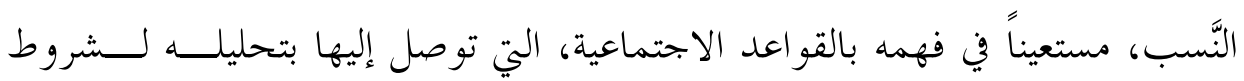

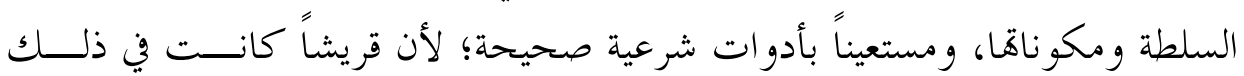

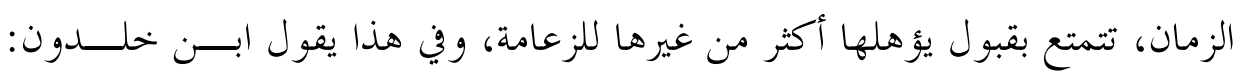

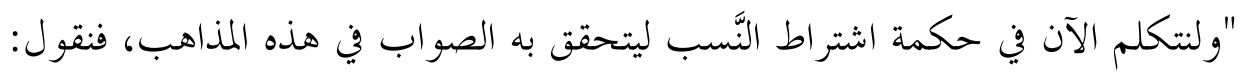

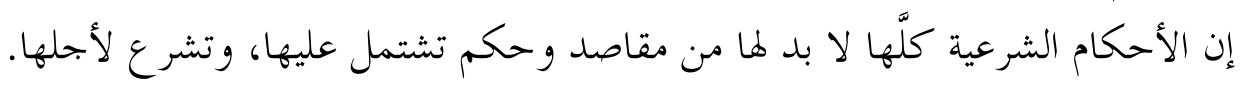

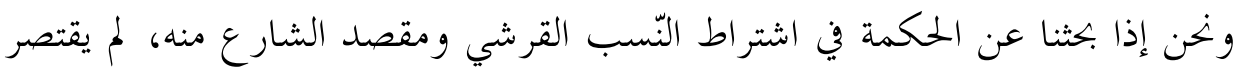

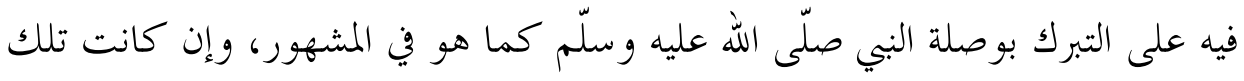

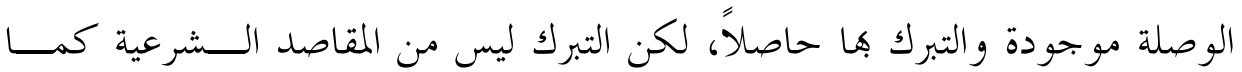

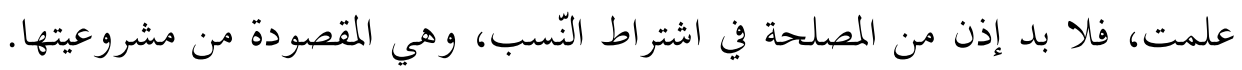

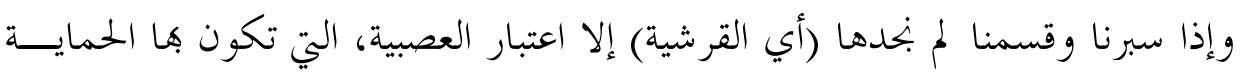

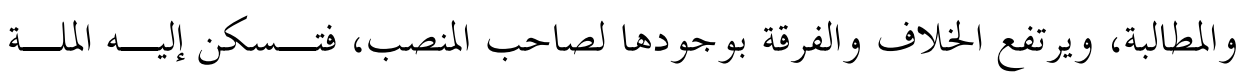

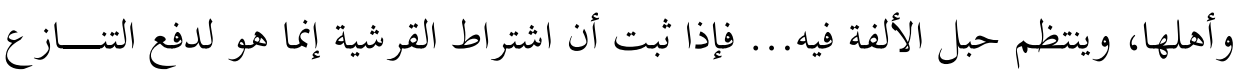

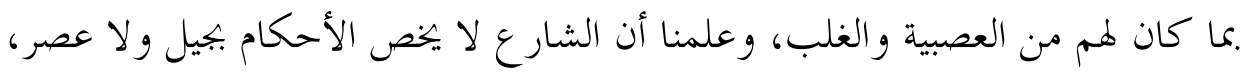

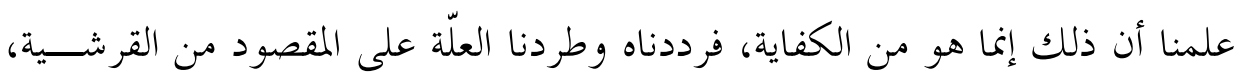

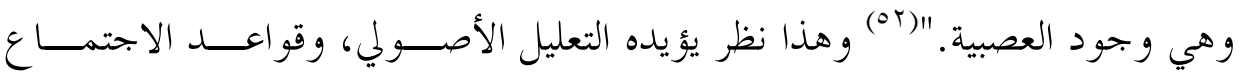

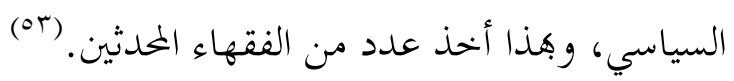

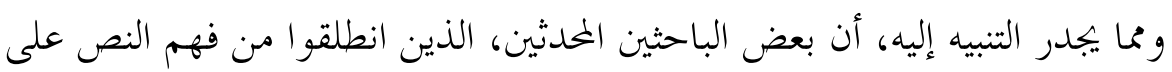

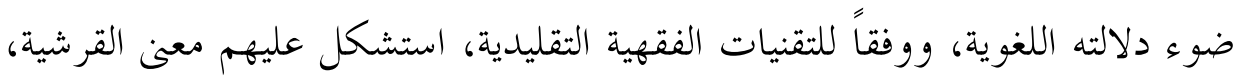

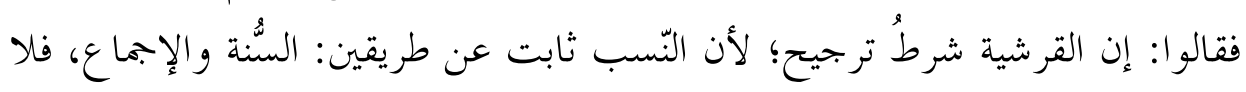

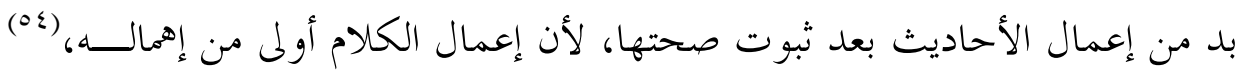

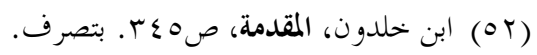

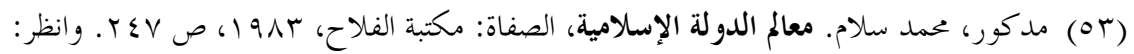

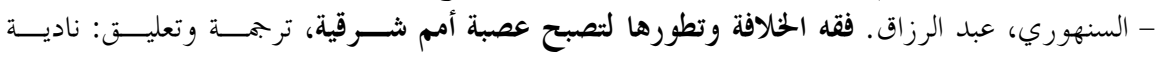

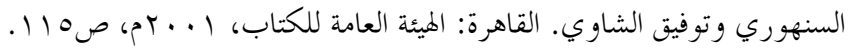

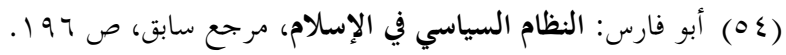


أي: إذا تساوى القرشي مع غيره في العلم و الجحدارة والكفاءة يُرجَّح القرشي، أمـــــا إذا كان غير القرشي أكفأ فهو أولى بالإمامة.

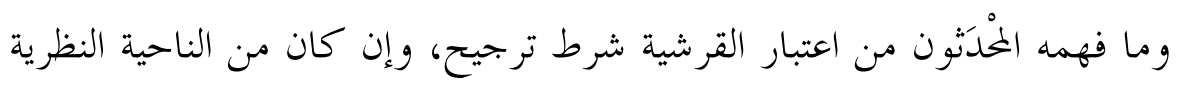

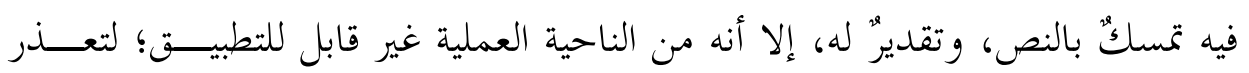

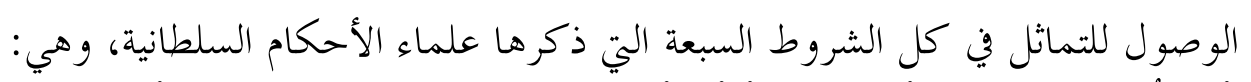

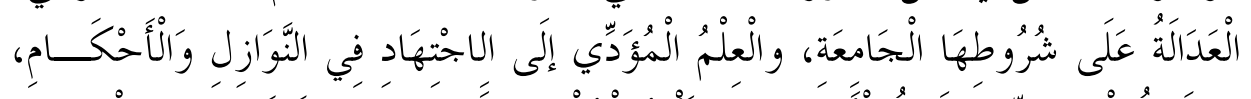

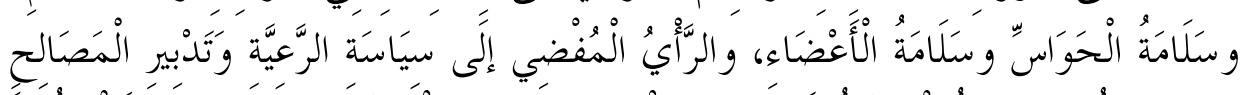

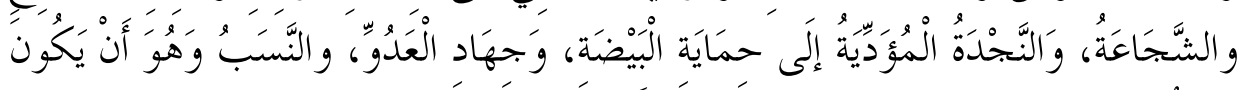

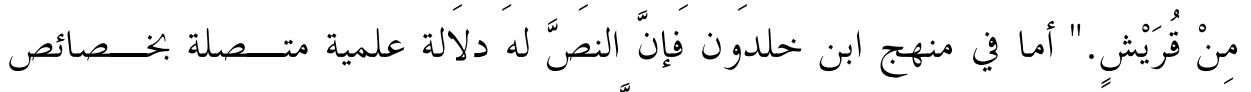

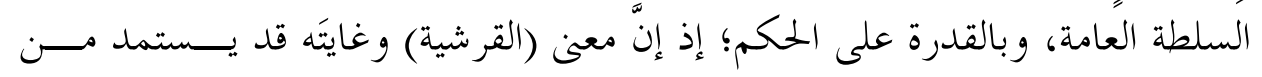

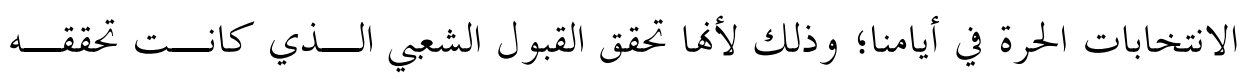

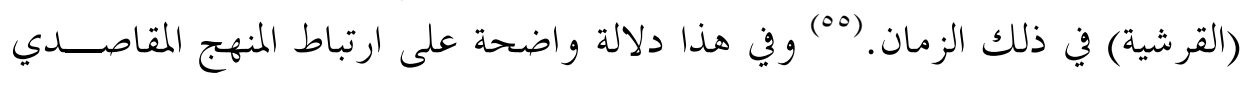
بالمنهج العملي.

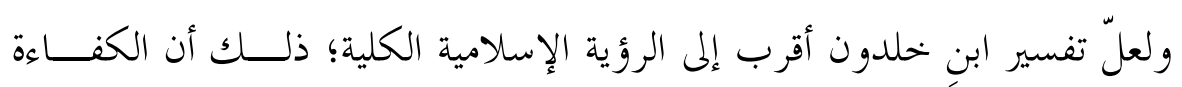

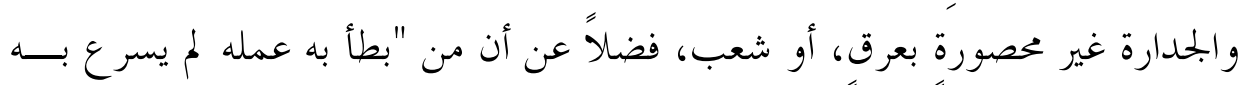

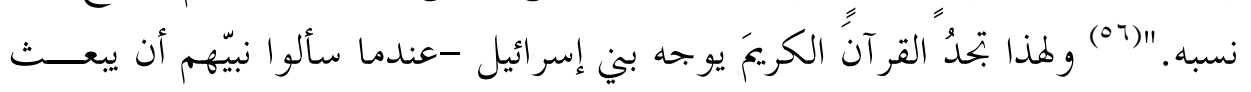

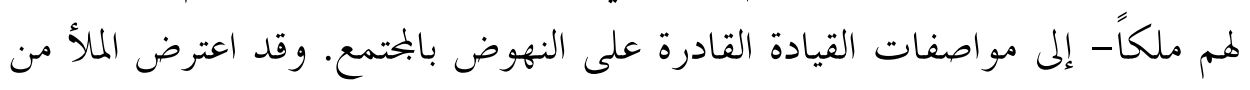

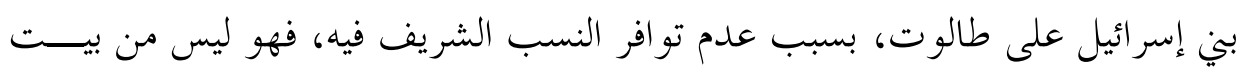

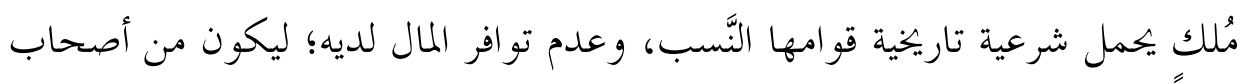

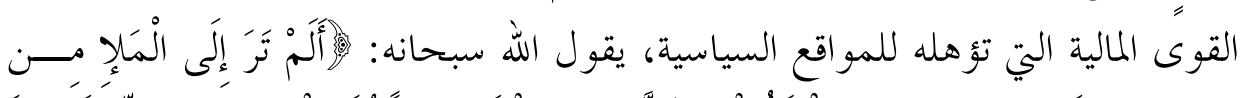

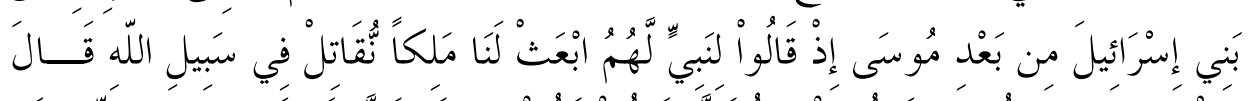

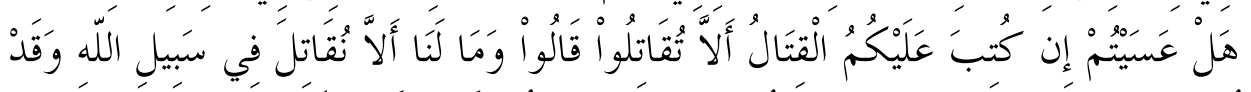

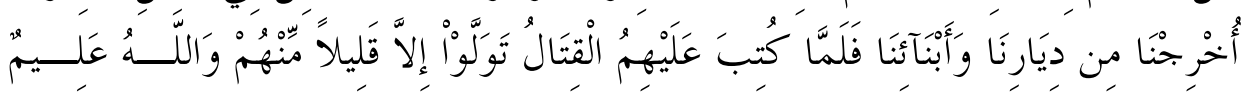

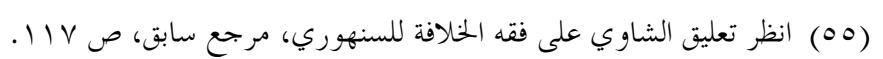

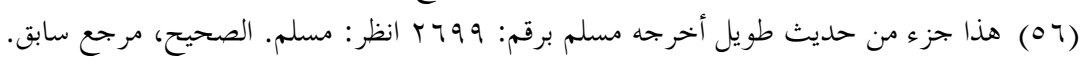




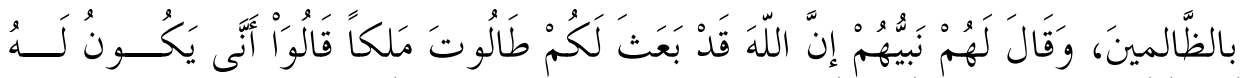

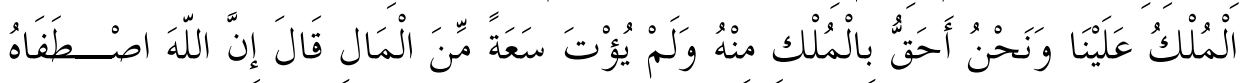

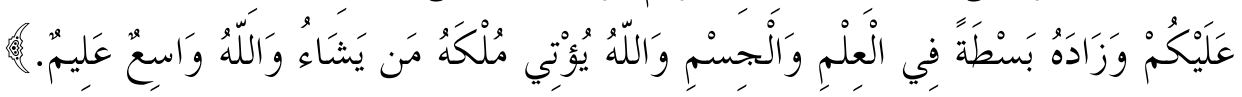

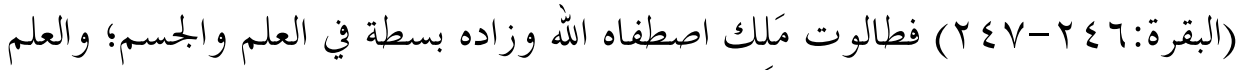

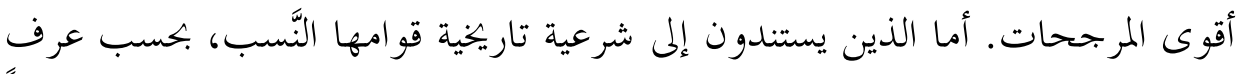

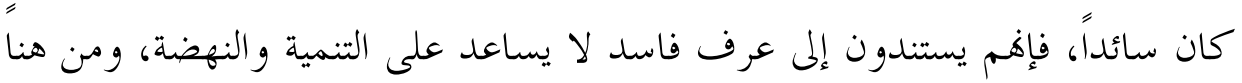

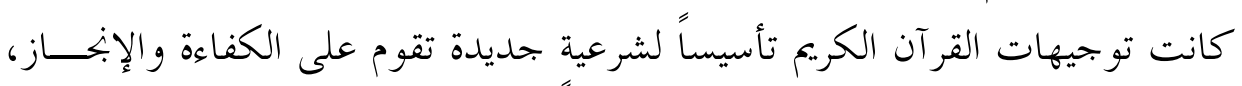

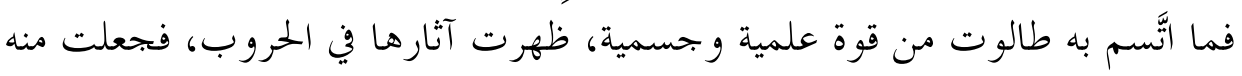
رجل المرحلة.

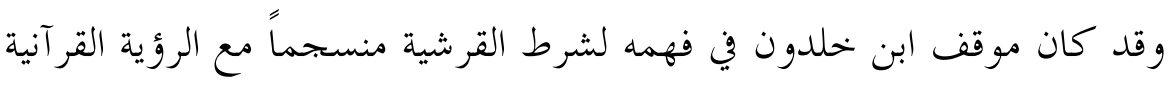

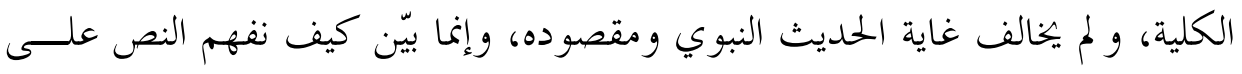

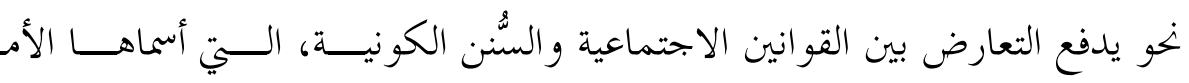

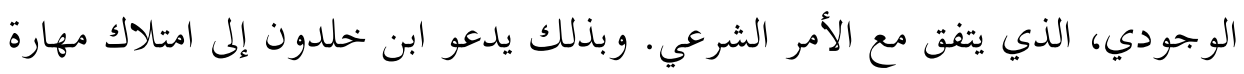

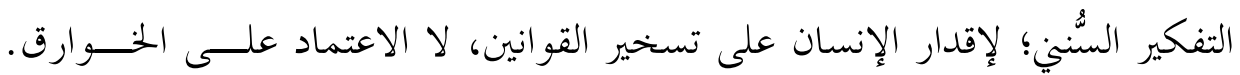

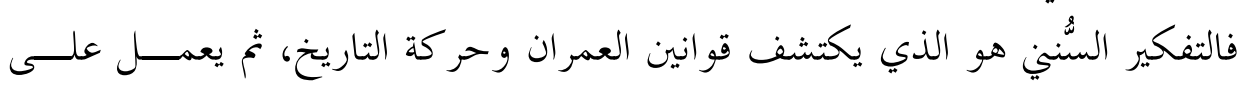

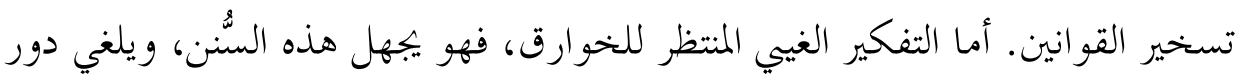

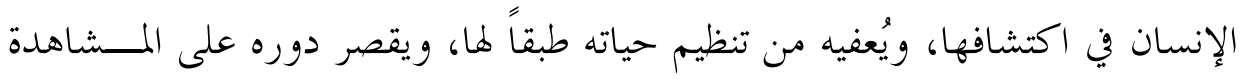

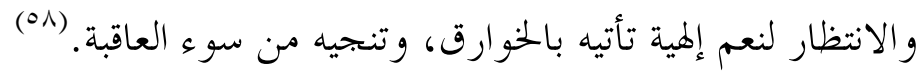

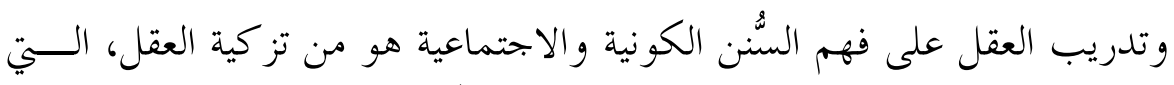

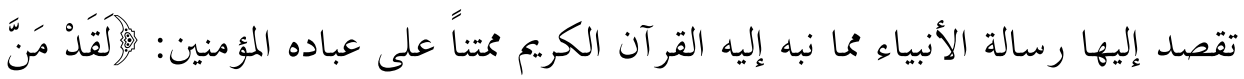

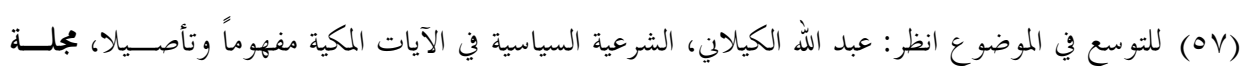

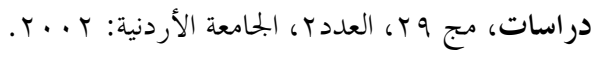

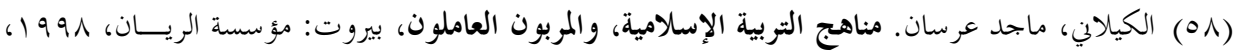




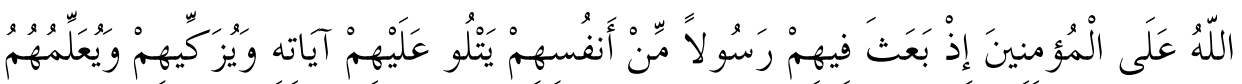

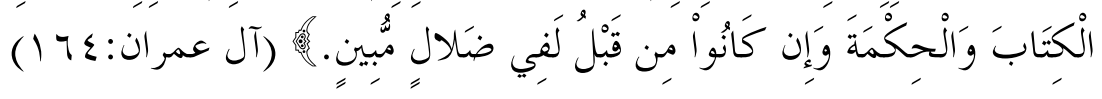

\section{r. منهج ابن خلدون في مناقشة النَّجْدات الذين أنكروا وجوب نصب الإمام:}

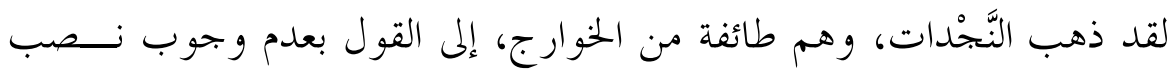

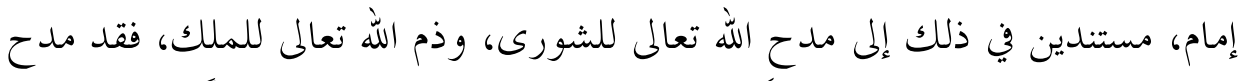

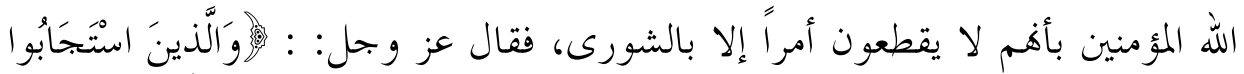

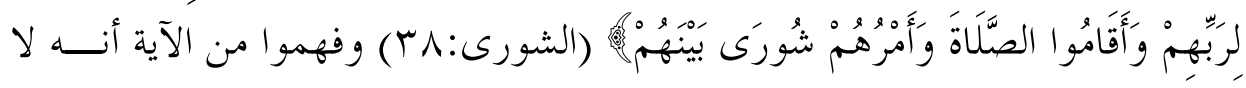

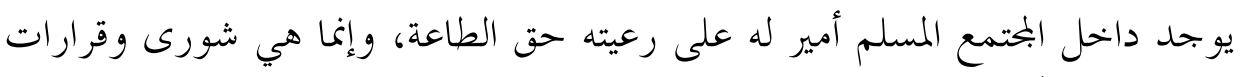

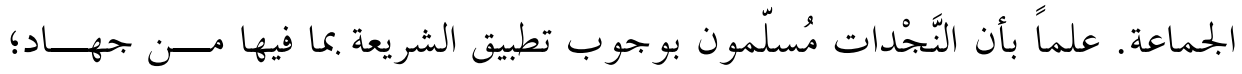

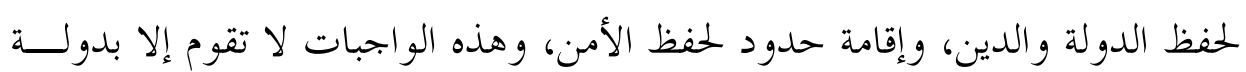
وأمير.

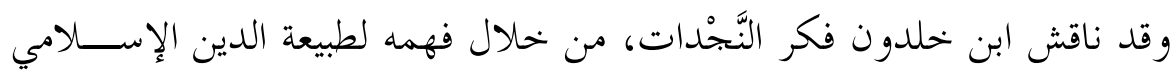

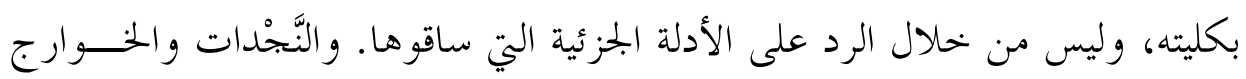

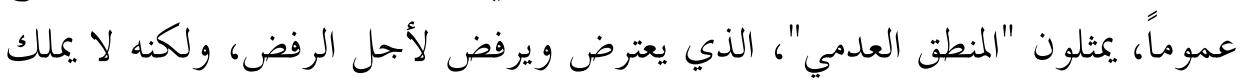

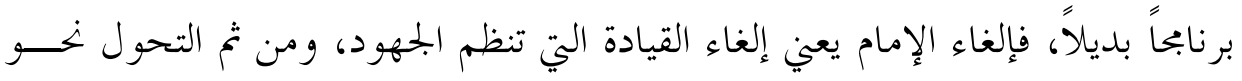

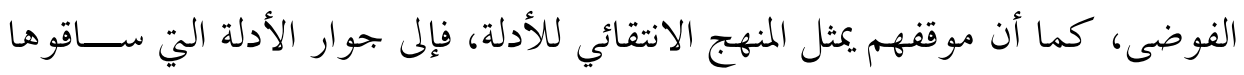

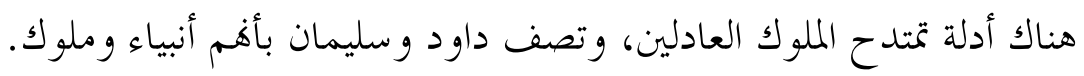

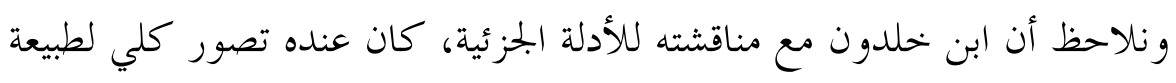

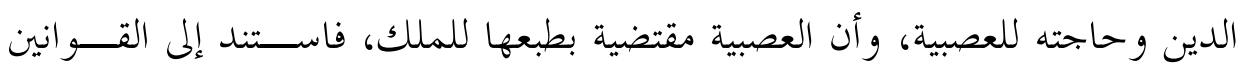

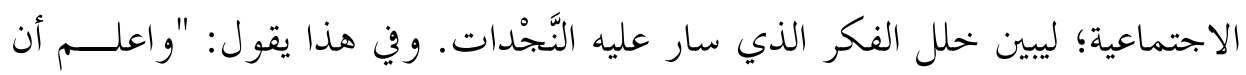

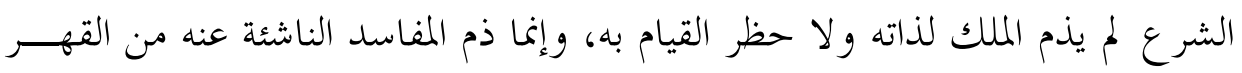

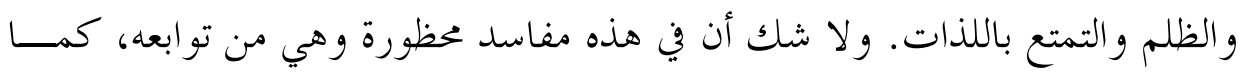

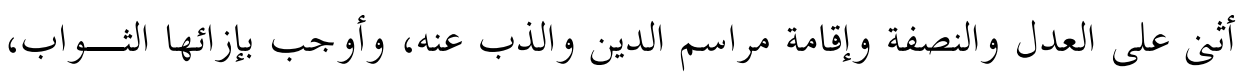


وهي كلها من توابع الملك. فإذاً، إنما وقع الذم للملك على صفة وحال دون حسال

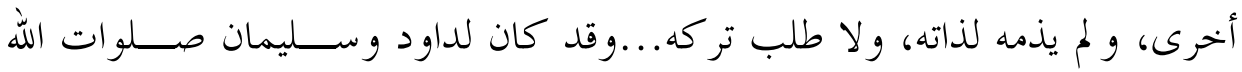

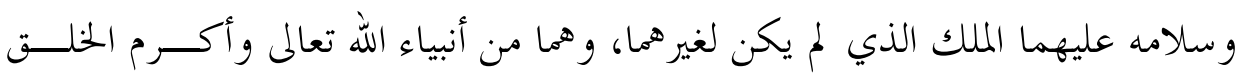

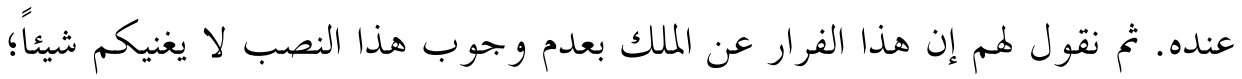

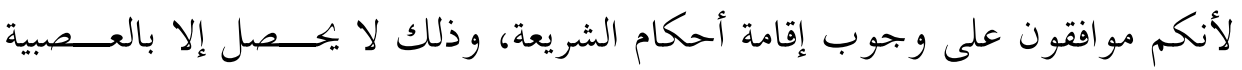

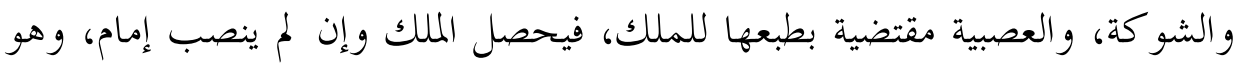

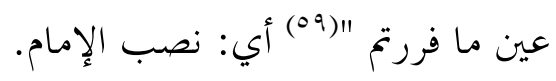

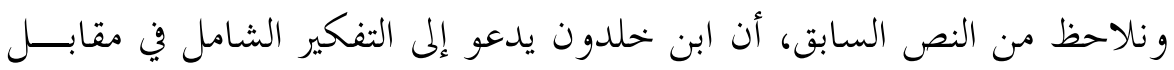

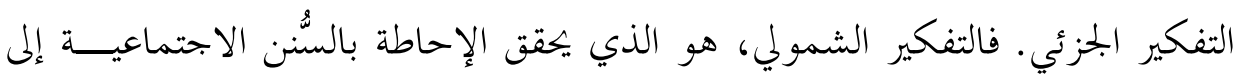

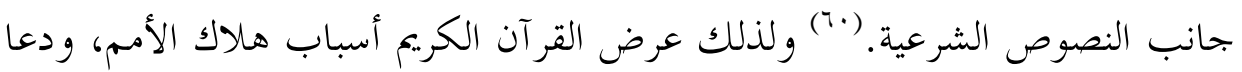

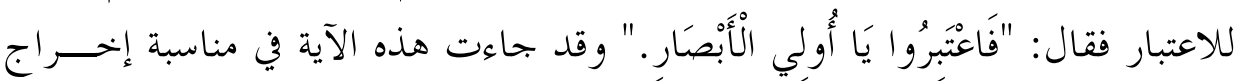

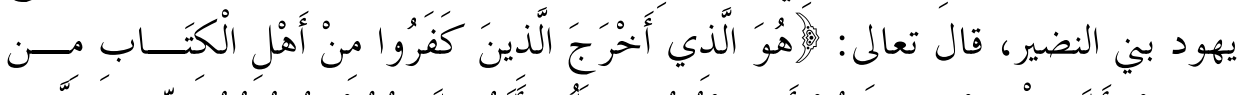

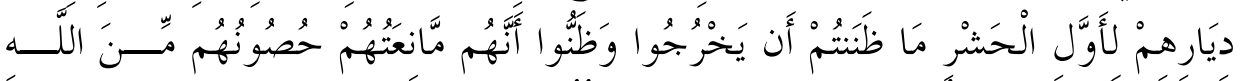

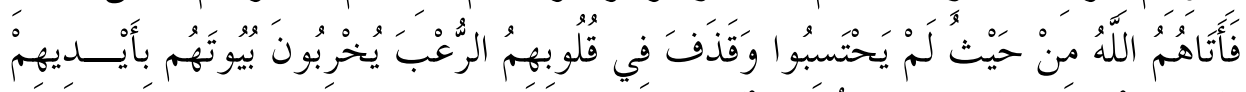

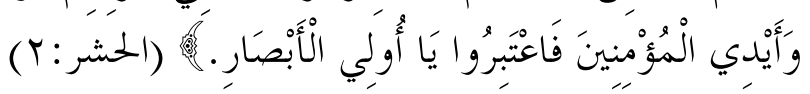

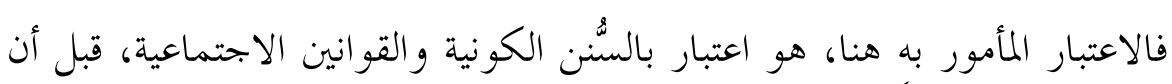

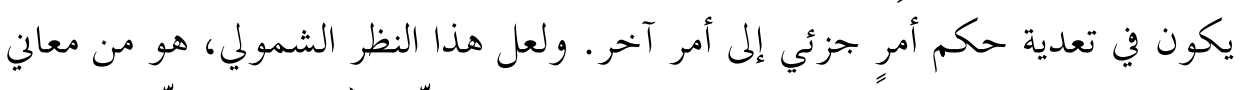

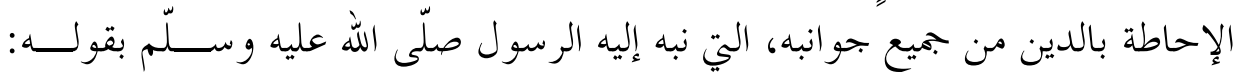

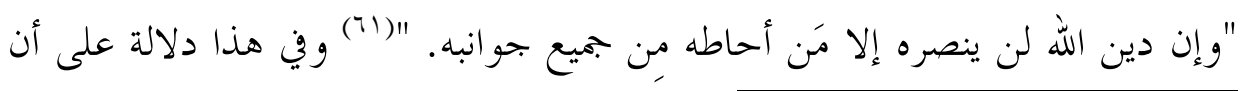

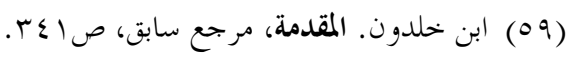

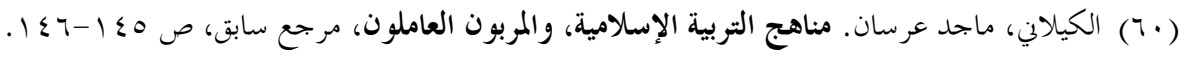

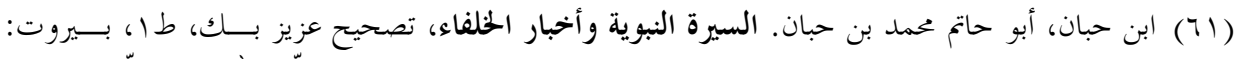

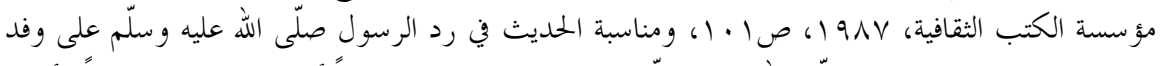

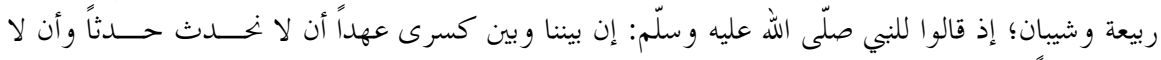

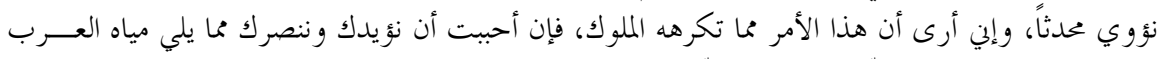

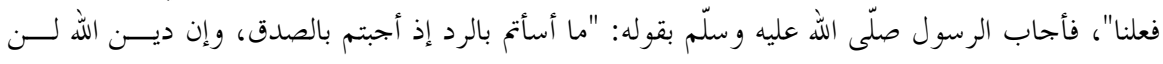
ينصره إلا مَن أحاطه من جميع جوانبه. 


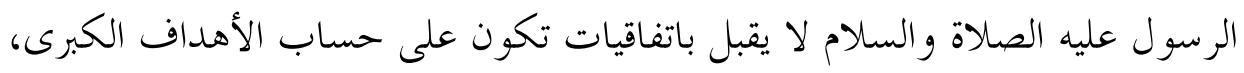

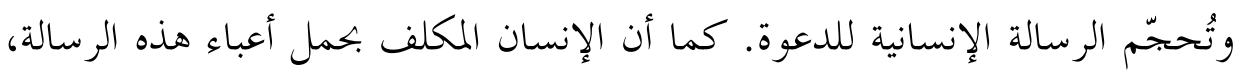

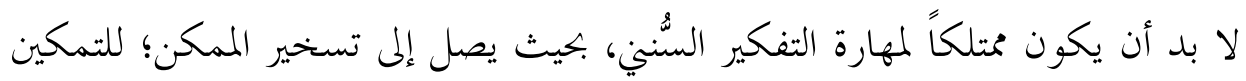
بالأرض.

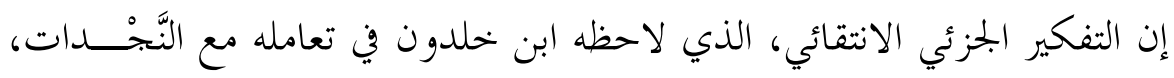

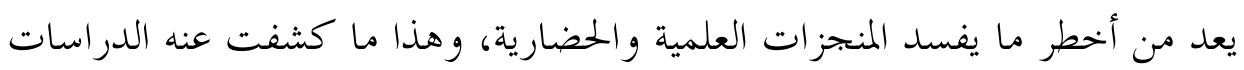

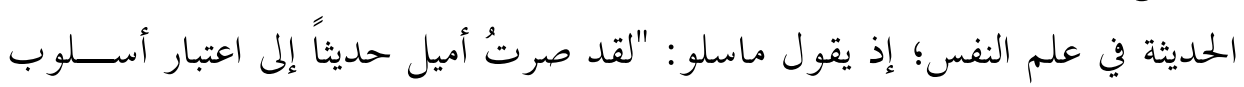

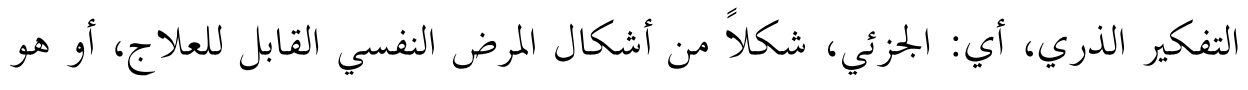

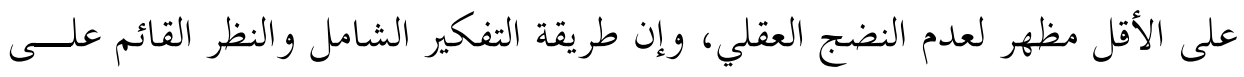

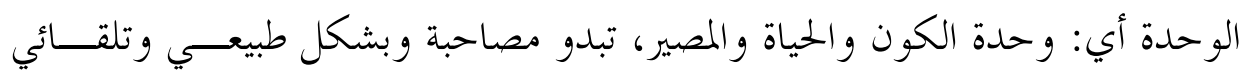

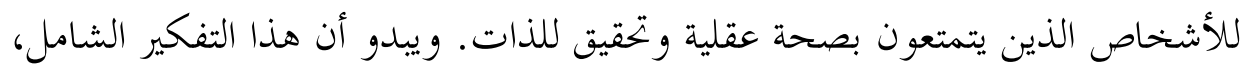

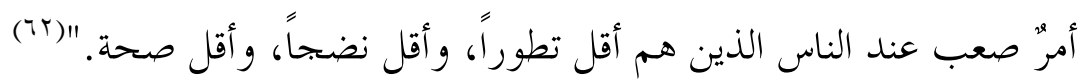

\section{ع ـ فهم ابن خلدون للنهي عن العصبية:}

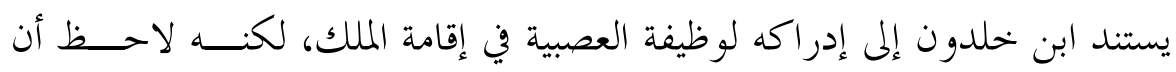

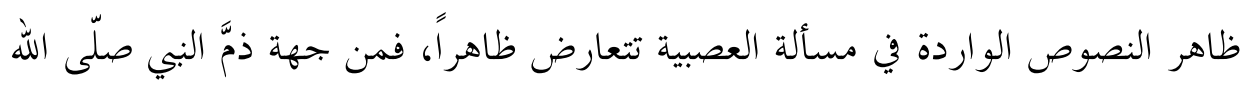

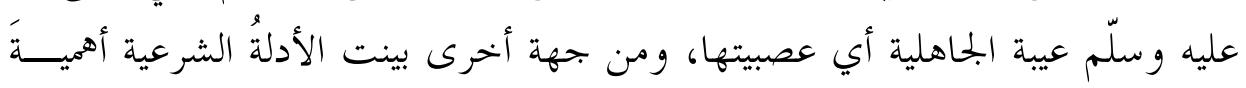

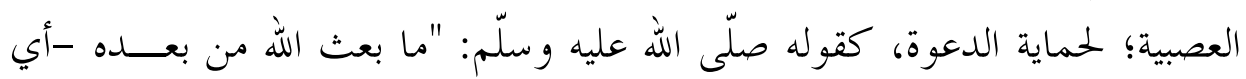

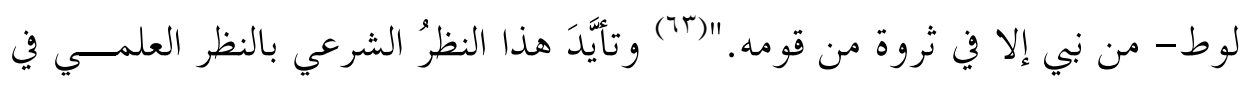
السُّن الاجتماعية.

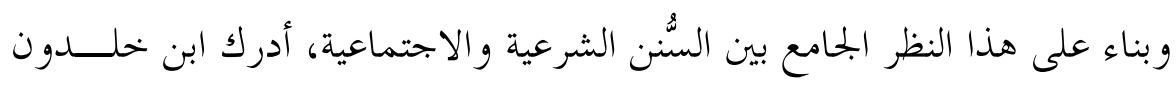

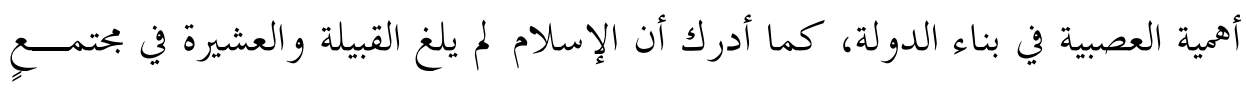

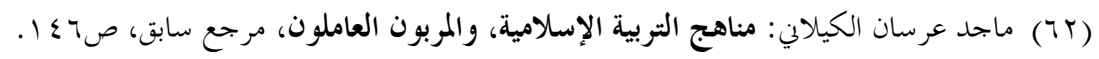

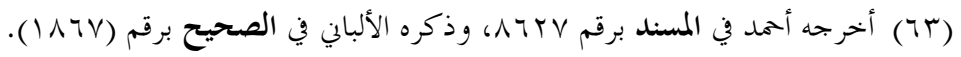


يتكون من بحموعة قبائل وعشائر، وإنما ألغى الانغلاق القبلي الذي يعيـق انــصهار القبائل في مفهوم الأمة، وفي هذا يقول: فئل وعنائر، وإنا

"اعلم أن الملك غاية طبيعية للعصبية، ليس وقوعه عنها باختيار، إنما هو بضرورة

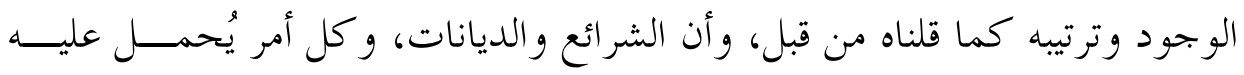

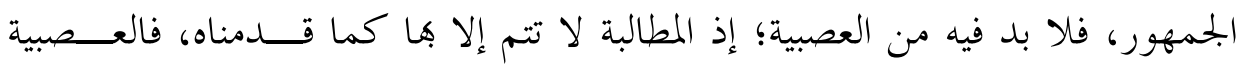

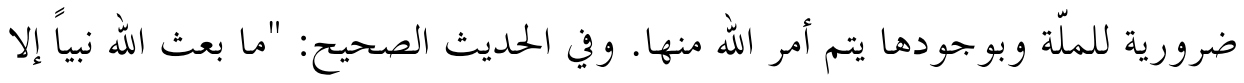

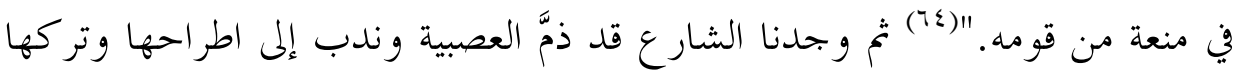

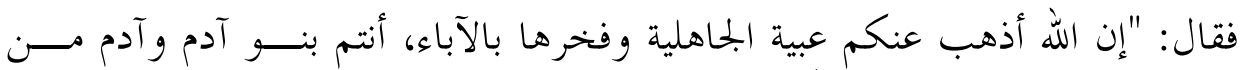

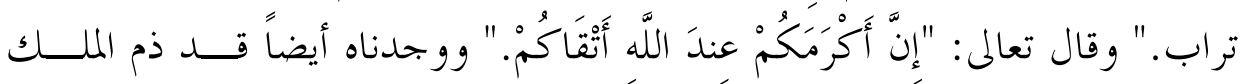

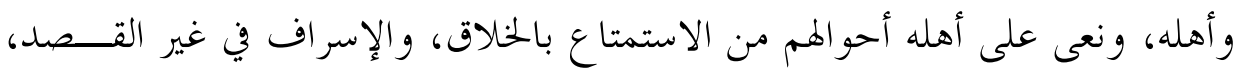

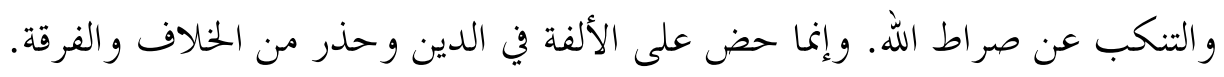

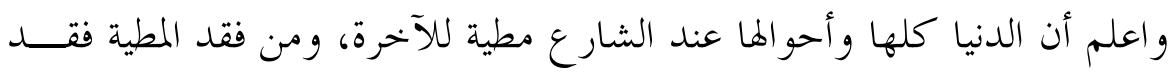

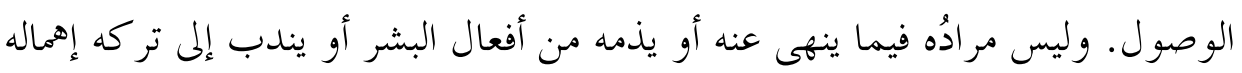

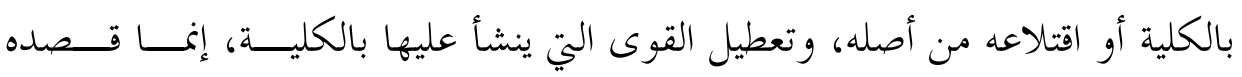

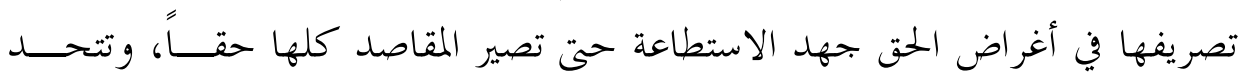

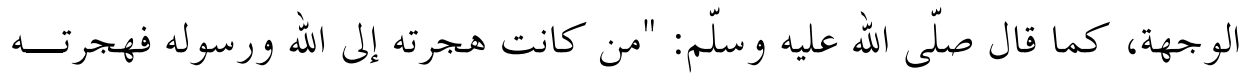

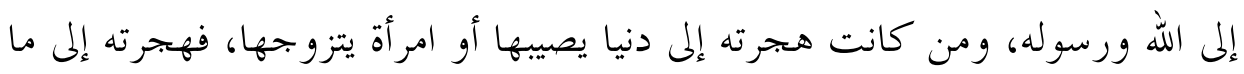

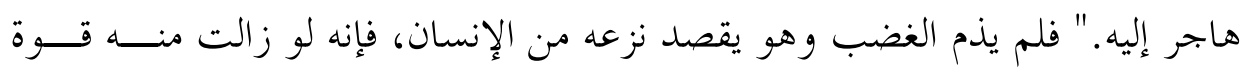

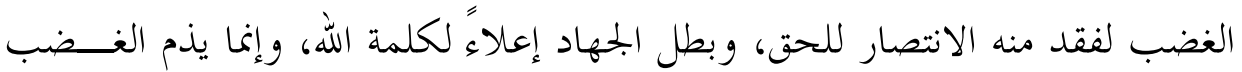

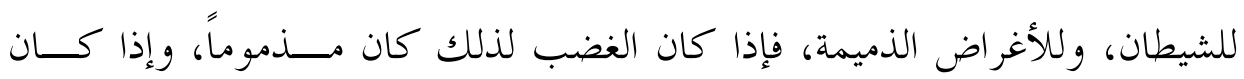

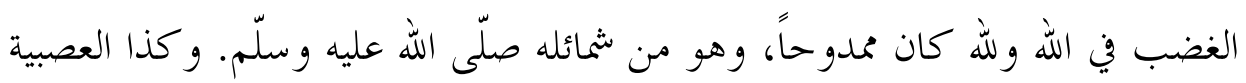

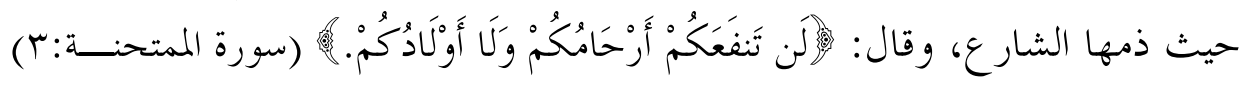

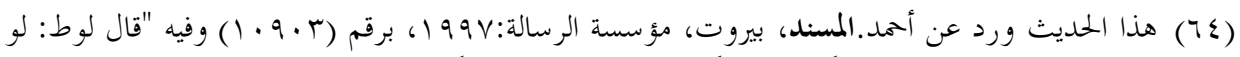

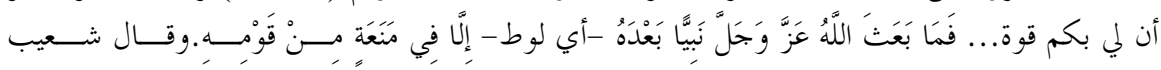
الأرناؤوط في تخريها: حديث صحيح. 
فإنما مراده حيث تكون العصبية على الباطل وأحو اله، كما كانت في الجماهليــة، وأن ألمان

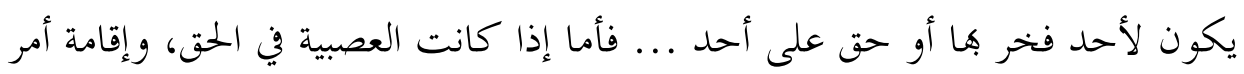

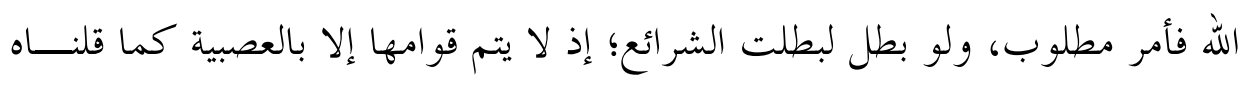
من قبل."(10) مطنو

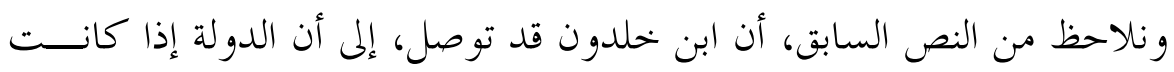

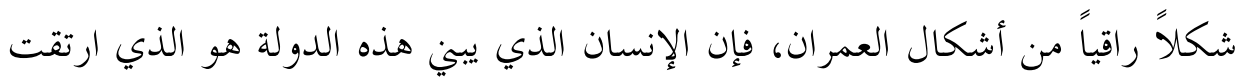

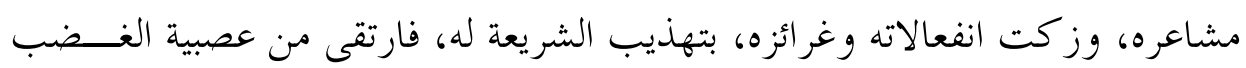

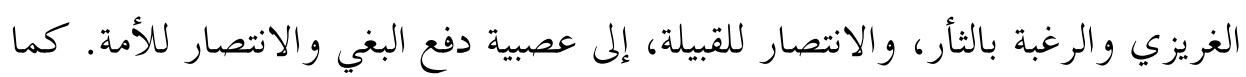

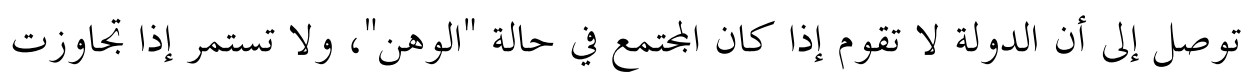

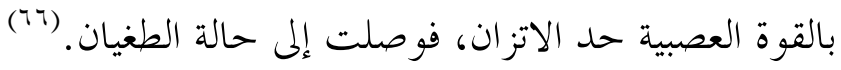

الحخاتمة:

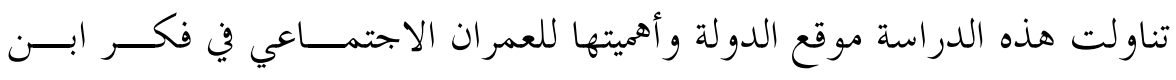
خلدون، وكشفت عن تحليل ابن خلدوون لعوامل القوة والضعف في أيّ بحتمع إنساني.

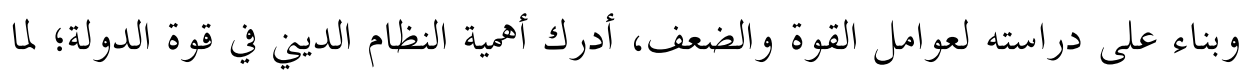

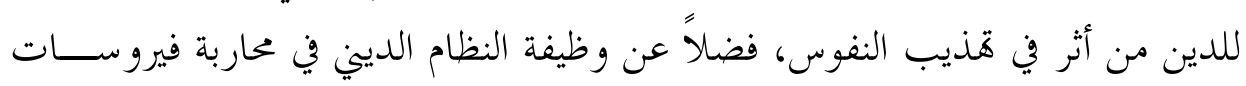

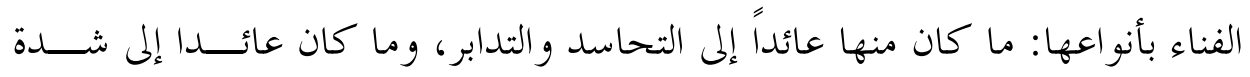

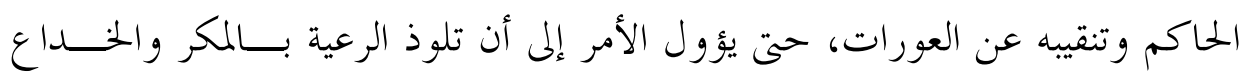
لحماية نفسها، فتفسد الدولة بفساد النيات. وقد كشف البحث عن المنهج العلمي الذي سار عليه ابن خلدون مـــن خــاليال

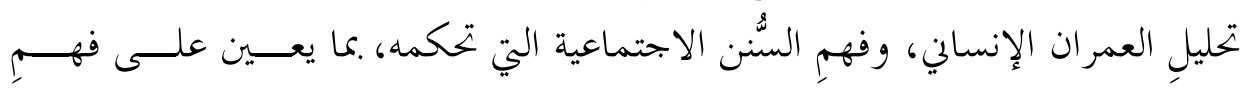




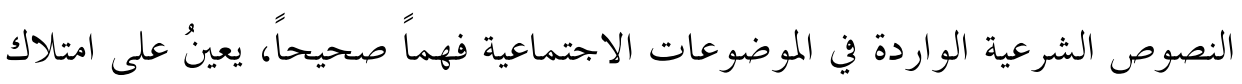

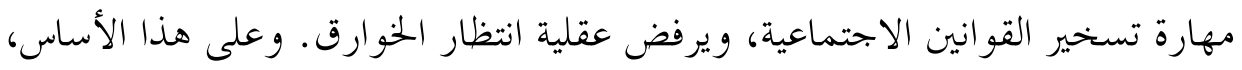

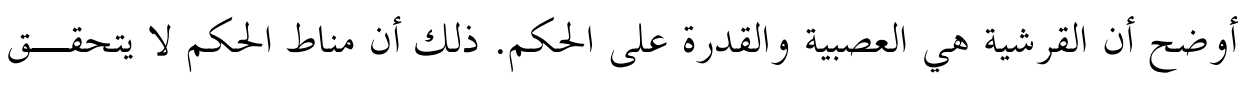

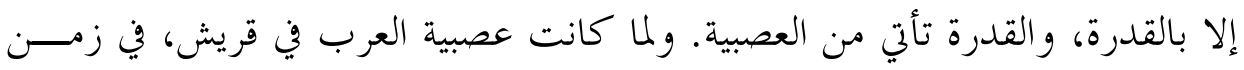

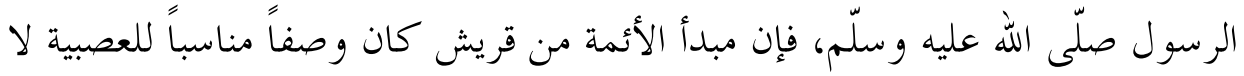

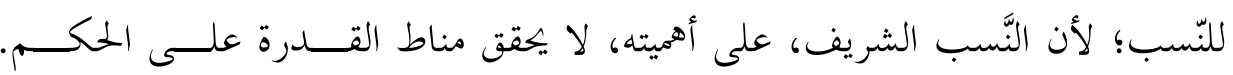

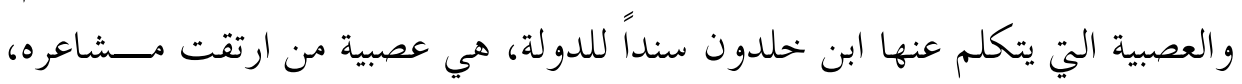

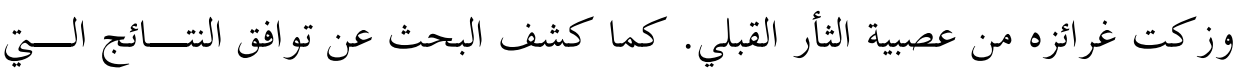

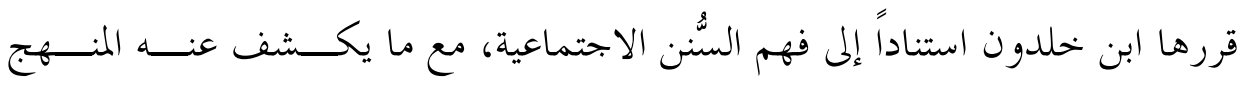

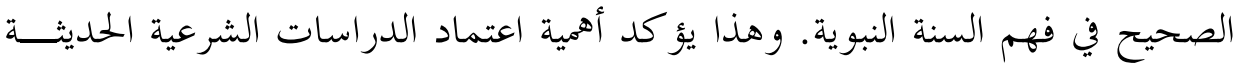

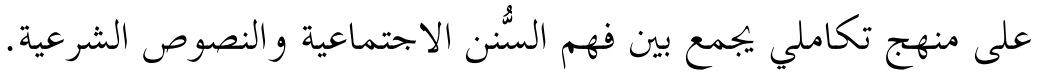

